\title{
KEYSTONE PROJECT
}

Final Report for the Keystone Feasibility Study December 1982

Work Performed Under Contract No. FG01-81FE16122

Westinghouse Electric Corporation

Madison, Pennsylvania 


\title{
DISCLAIMER
}

\begin{abstract}
This report was prepared as an account of work sponsored by an agency of the United States Government. Neither the United States Government nor any agency thereof, nor any of their employees, makes any warranty, express or implied, or assumes any legal liability or responsibility for the accuracy, completeness, or usefulness of any information, apparatus, product, or process disclosed, or represents that its use would not infringe privately owned rights. Reference herein to any specific commercial product, process, or service by trade name, trademark, manufacturer, or otherwise does not necessarily constitute or imply its endorsement, recommendation, or favoring by the United States Government or any agency thereof. The views and opinions of authors expressed herein do not necessarily state or reflect those of the United States Government or any agency thereof.
\end{abstract}

This report has been reproduced directly from the best available copy.

Available from the National Technical Information Service, U. S. Department of Commerce, Springfield, Virginia 22161.

Price: Printed Copy All

Microfiche A01

Codes are used for pricing all publications. The code is determined by the number of pages in the publication. Information pertaining to the pricing codes can be found in the current issues of the following publications, which are generally available in most libraries: Energy Research Abstracts (ERA); Government Reports Announcements and Index (GRA and I); Scientific and Technical Abstract Reports (STAR); and publication NTIS-PR-360 available from NTIS at the above address. 


\section{KEYSTONE PROJECT}

DOE/FE/10122--1491-Vol.4

DE84 002544

\section{Final Report for the Keystone Feasibility Study December 1982}

Prepared for the U.S. Department of Energy

Under Grant No. DE-FG01-81FE16122

DOE Program Manager D. C. Cicero

Westinghouse Project Manager J. D. Voytko

Principal Investigators:

AmeriGas

Air Products and Chemicals, Inc.

Bethlehem Steel Corporation

Davy McKee Corporation

Dravo Engineers, Inc.

Energy Impact Associates, Inc. Johnstown Area Regional Industries Lehman Brothers Kuhn Loeb, Inc.

Westinghouse Electric Corporation 


\section{DISCLAIMER}

This report was prepared as an account of work sponsored by an agency of the United States Government. Neither the United States Government nor any agency Thereof, nor any of their employees, makes any warranty, express or implied, or assumes any legal liability or responsibility for the accuracy, completeness, or usefulness of any information, apparatus, product, or process disclosed, or represents that its use would not infringe privately owned rights. Reference herein to any specific commercial product, process, or service by trade name, trademark, manufacturer, or otherwise does not necessarily constitute or imply its endorsement, recommendation, or favoring by the United States Government or any agency thereof. The views and opinions of authors expressed herein do not necessarily state or reflect those of the United States Government or any agency thereof. 


\section{DISCLAIMER}

Portions of this document may be illegible in electronic image products. Images are produced from the best available original document. 


\section{KEYSTONE PROJECT}

VOLUME I V

ORGANIZATION, MARKETING AND ECONOMIC PLANS

TABLE OF CONTENTS

$\underline{\text { Page }}$

1.0 PROJECT MANAGEMENT $1-1$

1.1 Introduction $1-1$

1.1.1 Plan Objectives 1-1

1.1.2 Plan Overview 1-2

1.2 Organizational Plan 1-2

1.2.1 Overall Management Structure 1-2

1.2.2 Design/Construction Phase Organization 1-7

1.2.3 Production Phase Organization 1-11

1.2.4 Staffing Plan $1-13$

1.3 Technical Plan 1-14

1.3.1 Work Breakdown Structure 1-17

1.3.2 Project Logic Networks 1-23

1.3.3 Project Schedules 1-23

1.4 Project Control System 1-34

1.4.1 Scheduling System Overview $1-35$

1.4.2 Total Project Cost Estimate 1-36

$\begin{array}{lll}\text { 1.4.3 Financial Control 1-37 } & \end{array}$

1.4.4 Technical Control 1-42

1.4.5 Procurement Control 1-46

$\begin{array}{lll}1.5 & \text { Risk Management Program } & 1-47\end{array}$

1.5.1 Responsibilities and Objectives $1-47$

1.5.2 Risk Identification Areas $1-48$

1.5.3 Risk Management Activities $1-48$

2.0 ECONOMIC AND FINANCIAL ANALYSES 2-1

2.1 Assumptions for Financial Analyses 2-1

2.2 Summary of Results 2-3

$4071 \mathrm{E}$ 
2.3 Financial Model 2-4

2.3.1 Pre-Production Expenditures 2-5

2.3.2 Operating Period Expenditures 2-8

2.3.3 Revenues 2-8

2.4 Tax Considerations 2-11

2.4.1 Tax Treatment During the Pre-Production Period 2-11

2.4.2 Tax Treatment During the Operating Period 2-12

2.5 Determination of the Financing P 7 an 2-12

2.5.1 Al1-Equity Case 2-12

2.5.2 No-Price Support Case 2-14

2.5.3 Base Case 2-14

2.5.4 Comparison Between Methanol Support Price and Forecasted Prices 2-14

2.6 Sensitivity Analys is $2-29$

2.6.1 Optimistic and Pessimistic Cases 2-33

2.7 Project Financing Plan 2-36

2.7.1 Loan Guarantee 2-39

2.7.2 Price Support 2-39

2.8 Available Financial Assistance for the SFC 2-40

2.8.1 SFC Loan Guarantees $2-41$

2.8.2 SFC Price Guarantees 2-41

2.8.3 SFC Purchase Agreements 2-42

2.8.4 SFC Direct Loan Authority 2-43

2.8.5 SFC Joint Ventures $2-43$

2.9 SFC Solicitation Requirements 2-44

2.10 Project Structure Options 2-45

2.10.1 Tax Benefits 2-45

2.10.2 Organizational Options 2-49

2.10.3 Ownership Options 2-49

2.11 Equity Financing 2-50

2.12 Debt Financing 2-51

2.12.1 Project Financing Alternatives 2-52 
3.1 Markets for Keystone Methanol 3-1

3.1.1 Market Segments 3-1

3.1.2 Market Area 3-3

3.2 Methanol Market Perspectives 3-7

3.2.1 International Methanol Perspective 3-7

3.2.2 Domestic Perspective 3-9

3.2.3 Pricing Perspective 3-11

3.3 Market Potential 3-13

3.3.1 Utility Fuel Market 3-13

3.3.2 Motor Fuel Blend Market 3-21

3.3.3 Neat Methanol Fuel 3-25

3.3.4 Chemical Market 3-33

3.4 Transportation of Methanol 3-34

3.4.1 Transportation Choices 3-34

3.5 Market Strategy and Plan 3-36

3.5.1 Types of Risk 3-36

3.5.2 Marketing Plan 3-37

3.5.3 Pricing 3-39

3.5.4 Conclusion 3-41

3.6 Regulatory and Legislative Impact 3-43

3.6.1 Utility Market 3-43

3.6.2 Blend Market 3-43

3.6.3 Neat Fuel 3-44

3.6.4 Storage and Handling 3-44

3.6.5 Legislative Action 3-44

3.7 By-Products Markets 3-45

3.7.1 Carbon Dioxide Market 3-45

3.7.2 Sulfur Market 3-48

3.7.3 Ammonia Market 3-49 


\section{TABLE OF CONTENTS}

\section{(cont inued)}

4.0 PROCESS LICENS ING AND AGREEMENTS

4-1

4.1 Summaries of Agreements or Proposed Agreements 4-1

4.1 .1 Process Licenses 4-2

4.1.2 Performance Guarantees 4-2

4.1.3 Project Financing, Project Agreement and Partnership Agreements

4.2 Litigation 4-3

4.2.1 Process Licenses 4-3

4.2.2 Water Rights 4-4

4.2.3 Mineral Rights 4-4

4.2.4 Land Availability 4-5

4.2.5 Other Litigation Potential 4-5

4.3 Rights of Access to Land 4-6

4.3.1 Current Status of Site Ownership 4-6

4.4 Replicability of Project 4-6

\section{APPENDI CES}

Appendix A Prime Engineering Contractor--Project Execution Plan

Appendix B Prime Construction Contractor--Construction Activities Plan

Appendix $C$ Detailed Assumptions Underlying the Base Case Financial Projections 
VOLUME IV

LIST OF FIGURES

Figure

$\underline{\text { Page }}$

1.2-1 Keystone Associates Executive Level Management Structure 1-4

1.2-2 Key Management Professional and Non-Professional Functions 1-8

1.2-3 Organization Chart--Production Phase 1-12

1.2-4 Project Staffing Plan 1-16

1.3-1 Work Breakdown Structure 1-18

1.3-2 Schedule of Activities for WBS $3000 \quad 1-21$

1.3-3 Project Level I Logic Diagram 1-24

1.3-4 Level II Project Schedule 1-25

$\begin{array}{lll}\text { 1.3-5 Overall Keystone Project Schedule 1-27 } & \text { 1. }\end{array}$

1.4-1 Cost Account Planning and Reporting (CAPR) Forms-Keystone Project 1-38

1.4-2 Example of Data Information Cover Sheet (DIS) 1-44

1.4-3 Project Configuration Control System 1-45

1.5-1 SASOL/Keystone Comparison Schedule 1-50

2-1 Comparison of Methanol Prices 2-28

2-2 Methanol Price by Year During Price Support Period 2-38

2-3 Construction Financing with Commercial Paper 2-53

2-4 Comparison of Yield Between 3-Month U.S. Treasury Bill and 3-Month Commercial Paper 2-54

2-5 Project Financing with Direct Debt Instruments 2-55

3-1 Geographical Location of the Keystone Product Market Areas 3-6

3-2 Products Derived from Methanol 3-8

3-3 Projected Natural Gas and Methanol Prices from Several Sources 3-14

3-4 Price Projections for Domestic and Canadian Producers 3-15

3-5 Expected Range of Values of Methanol as an Octane Enhancer 3-38

3-6 Required Keystone Methanol Price Compared with Various

Market Prices 3-42 
VOLUME IV

LIST OF TABLES

Table

$\underline{\text { Page }}$

1.2-1 Year-by-Year Staffing Plan for the Keystone Associates

$1-15$

1.3-1 Keystone Project Work Breakdown Structure

$1-28$

1.5-1 Keystone Project Risks and Mitigation Strategies 1-52

2-1 Keystone Project Major Financial Analys is Assumptions 2-2

2-2 Pre-Production Costs (Excluding Financing) 2-6

2-3 Financing Requirements During Pre-Production Period 2-7

2-4 Summary Financial Results 2-13

2-5 Base Case Pro-Forma Financial Statements 2-15

2-6 Sensitivity Analysis $2-32$

2-7 Effect of Target Rate of Return on Required Price Supports 2-34

2-8 Modification of Base Case Assumptions for the Optimistic and Pessimistic Cases $2-35$

2-9 Comparison of Results from Base Case, Optimistic Case and $\begin{array}{ll}\text { Pessimistic Case } & 2-37\end{array}$

2-10 Peat Methanol Associates (PMA) Summary Term Sheet 2-46

2-11 1982 U.S. Government-Guaranteed Ship Financing Bonds and Notes

2-12 Representative Term Sheet Synthetic Fuels Project with Government-Guaranteed Debt

3-1 Methanol Market Segments 3-2

3-2 Results of Methanol Market Contacts 3-4

3-3 U.S. Chemical Methanol Consumption by End Product 3-10

3-4 North American Methanol Supply and Demand 3-12

3-5 Competitive Fuel Prices 3-20

3-6 U.S. Gasol ine Use by Grade 3-23

3-7 Major Refiners in Keystone Market Area 3-26

3-8 Keystone Market Area Fleet Census Data 3-29

3-9 Keystone Market Area Metropolitan Areas in Top Fifty $\begin{array}{ll}\text { Fleet Census } & 3-30\end{array}$

3-10. Ford Motor Company's Plan for Introducing Neat-Fueled Vehicles to the U.S. Market 3-31

3-11 Scenario for Development of a Neat Motor Fuel Fleet 3-32

3-12. Methanol Transportation Choices 3-35 
SECTION 1.0

PROJECT MANAGEMENT

\subsection{INTRODUCTION}

This section contains the Project Management $\mathrm{Plan}$ for the Keystone coal-to-methanol project. It describes how the project will be organized, managed, directed and controlled beginning January 1983 with completion of a wide-ranging feasibility study.

This Project Management $P l a n$ will guide the project through all phases of activity leading to sustained plant operation and production of methanol.

\section{1 .1 PLAN OBJECTIVES}

The primary objective of the Project Management $P l a n$ is to describe how the Keystone Project will be organized and managed during each major phase of remaining work. These phases include:

- Completion of process design and plant engineering

- Procurement

- Construction

- Commercial operation

It is intended that the Keystone Project will be owned and operated by Keystone Associates, a partnership organization being formed by potential equity investors in the project. Consequently, the Management Plan is written from the perspective of Keystone Associates.

The plan will evolve as work proceeds and is subject to revision. However, it provides a starting point for proceeding with the many negotiations, discussions and agreements that must be completed on the project.

$4071 E$ 


\subsubsection{PLAN OVERVIEW}

This plan will define the technical and organizational plans for the project, including the work requirements, management roles, relationships and responsibilities that must be successfully fulfilled. It will also describe the management systems and procedures to be used for controlling engineering, cost and schedule. Finally, the plan will identify the project's risk management program for identifying, assessing and mitigating those risks that could potentially have a significant impact on successful realization of the project .

\subsection{ORGANIZATIONAL PLAN}

This section describes the organizational structure for the Keystone Project as well as functional relationships for the participants and management team. The organization of the project provides adequate management and professional support throughout all phases of the project. Excessive personnel have been avoided.

The management $\mathrm{plan}$ will insure that the project remains within budget and schedule. All technical inputs will be properly interfaced and implemented, and all partner business objectives will be met. The plan will also insure that the business of producing and marketing the plant's products is successful and that all regulatory and environmental requirements are achieved.

\subsubsection{OVERALL MANAGEMENT STRUCTURE}

The project will be structured as a general partnership among the major shareholders. This organization will be known as Keystone Associates. Additional limited partners may also participate through the ownership of equity shares. It is expected that general partners will own and control approximately 60 to 70 percent of project shares, with limited partners owning the remainder. A total of five general partners are anticipated, with each holding blocks of from 5 to 30 percent of the equity. Once the shares are offered, a larger number of limited partners are also anticipated. 


\subsubsection{Board of Directors}

The general partners will control the project and resulting methanol fuel business through a Board of Directors. Each partner will provide one such director who will be entitled to vote in proportion to the shares owned by the parent organization. A Board Chairman will be elected from among the Board members. The Board will include the Keystone Associates General Manager and the General Counsel, both of whom will be non-voting members. This Board will be responsible for all technical, business, legal and other actions on behalf of the parent firms. It will insure that the objectives of the parent firms are properly and adequately considered in all business decisions, while maintaining Keystone Associates as an independently functioning business entity.

\subsubsection{Organization Chart}

Figure 1.2-1 illustrates the executive level management structure of Keystone Associates, the business entity under which the Keystone Project will be owned and operated once all contractual commitments among the partners are completed. Personnel performing functions within this organization will be employees of the firm and will not be associated with the partner or owner firms.

\section{General Manager}

The Keystone General Manager will be responsible to the Board for day-to-day operation of the business. The manager will be assisted by a General Counsel from an independent law firm that can provide necessary legal counsel for all of Keystone Associates' business operations.

The General Manager will operate the business through Department Managers, each responsible for a segment of the firm's operations. The number of these Department Managers and their staff levels will change during various phases of the project, resulting in personnel who will be available to provide support only when needed but will not be a cost burden when they are not needed. For example, during the design and construction phase, the Project

$4071 \mathrm{E}$ 


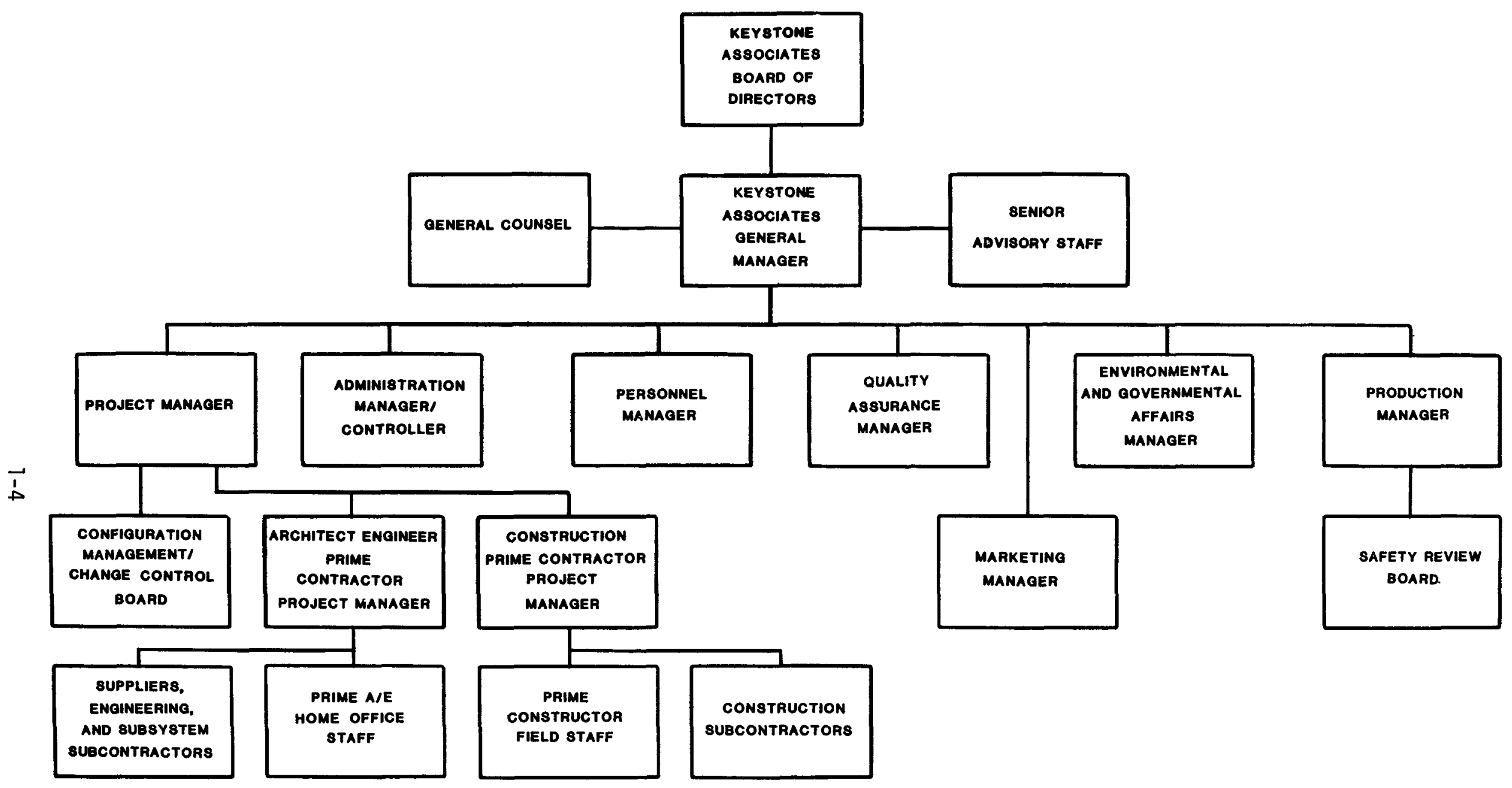

Figure 1.2-1 Keystone Associates Executive Leve1 Management Structure 
Management organization will be fairly large, while the Production Department will be quite small. In the production phase, the Production Department will be the largest group, while the Project Management organization will be replaced by a much smaller Engineering Department. The evolutionary nature of this organization is discussed more fully in subsequent sections of this plan.

\section{Project Manager}

The Project Manager is primarily responsible for successful implementation of plant design and construction. The Manager is responsible for all of the planning, budgeting, engineering and construction activities and for controlling these activities to meet all technical, financial and schedule objectives. The Project Manager's job is finished when the plant is mechanically complete, all subcontractor work is done, and the plant enters the production phase.

As shown in Figure 1.2-1, the Keystone Project Manager will handle the project by using the architect-engineering prime contractor, responsible for plant design and engineering, and the construction prime contractor, responsible for plant construction. Each of these major contractors will assign a Project Manager, who will direct the work within their respective organizations. All subcontracted engineering and construction work will also be controlled by these prime contractors. (Appendixes $A$ and $B$ of this plan provide the methods for project execution by the prime engineering and the prime construction contractors, respectively. In practice, these functions may be performed by one engineering-procurement-construction (EPC) contractor. This decision will be made by the General Manager during the pre-engineering phase in 1983.)

\section{Department Managers}

The General Manager's line management includes six additional Department Managers responsible for other ongoing functional areas of the business:

- The Administration Manager will be responsible for purchasing, accounting and other business-related functions.

$4071 \mathrm{E}$ 
- The Personnel Manager will perform all staffing, training, salary administration and related personnel relations activities.

- The Quality Assurance Manager will head a department responsible for quality engineering, quality control and other functions necessary to insure that all project quality requirements are achieved.

- The Marketing Manager and his staff will handle all business-related financial analyses, marketing communications and market development activities required to sell the methanol and by-products.

- The Manager of Environmental and Governmental Affairs will assure the environmental compatibility of the project and interface with local and governmental agencies regarding permits, licenses, socioeconomics and related issues.

- The Production Manager will be the key person for the ongoing production phase, with primary responsibility for producing products at minimum cost.

Senior Advisory Staff

The General Manager will be assisted by a Senior Advisory Staff, consisting of three experienced people, particularly skilled in the areas of business operations, technology and fuels marketing. Along with the General Counsel, this group will provide a readily available source of staff expertise to help the General Manager guide the business in the world's complex and uncertain energy climate. These personnel will have no line management function and will, therefore, be free to operate across functional lines to provide an overview. A major function of this group is to insure that all activities are carried out to minimize risks to the project arising from technical, financial, regulatory and marketing areas. 
The Project Manager will use a Configuration Management/Change Control Board as the main instrument for controlling the design of the plant throughout the design and construction period. This Board will be responsible for reviewing all change notices, both engineering and field, to insure that project specifications and process design basis specifications are achieved as written or modified by previous Board actions. The Board is also responsible for monitoring all project documentation to assure that proper design reviews have occurred, and that all changes are traceable and documented. Membership will consist of the Deputy Project Manager for Construction, the Deputy Project Manager for Engineering, the Project Control Manager, the Quality Assurance Manager, the Production Manager and the Manager of Environmental and Governmental Affairs. This broad membership insures that all major functional interfaces and requirements will be met by the engineering design.

\section{Safety Review Board}

Plant operation will be maintained with due regard for the safety of plant personnel and equipment. Safety aspects of plant operation will be continually reviewed by a Safety Review Board, which will pass judgment on all plant operations or planned modifications. Board membership will consist of a Shift Superintendent, a Maintenance Superintendent, a Safety Engineer, the Personnel Manager and the Plant Technical Support Manager.

\subsubsection{DES IGN/CONSTRUCTION PHASE ORGANIZATION}

As noted above, the Keystone Project organization will evolve as the project proceeds, changing in numbers of people and in function as the project proceeds through various phases. In the early stages, emphasis will be on plant design and construction activities. Figure 1.2-2 amplifies the previous executive level organization chart (Figure 1.2-1) to show the detailed functional and staffing plan for each of the previously described departments. The personnel assigned to each group will consist of management, professionals, technicians, craftspersons, draftspersons, operators and 


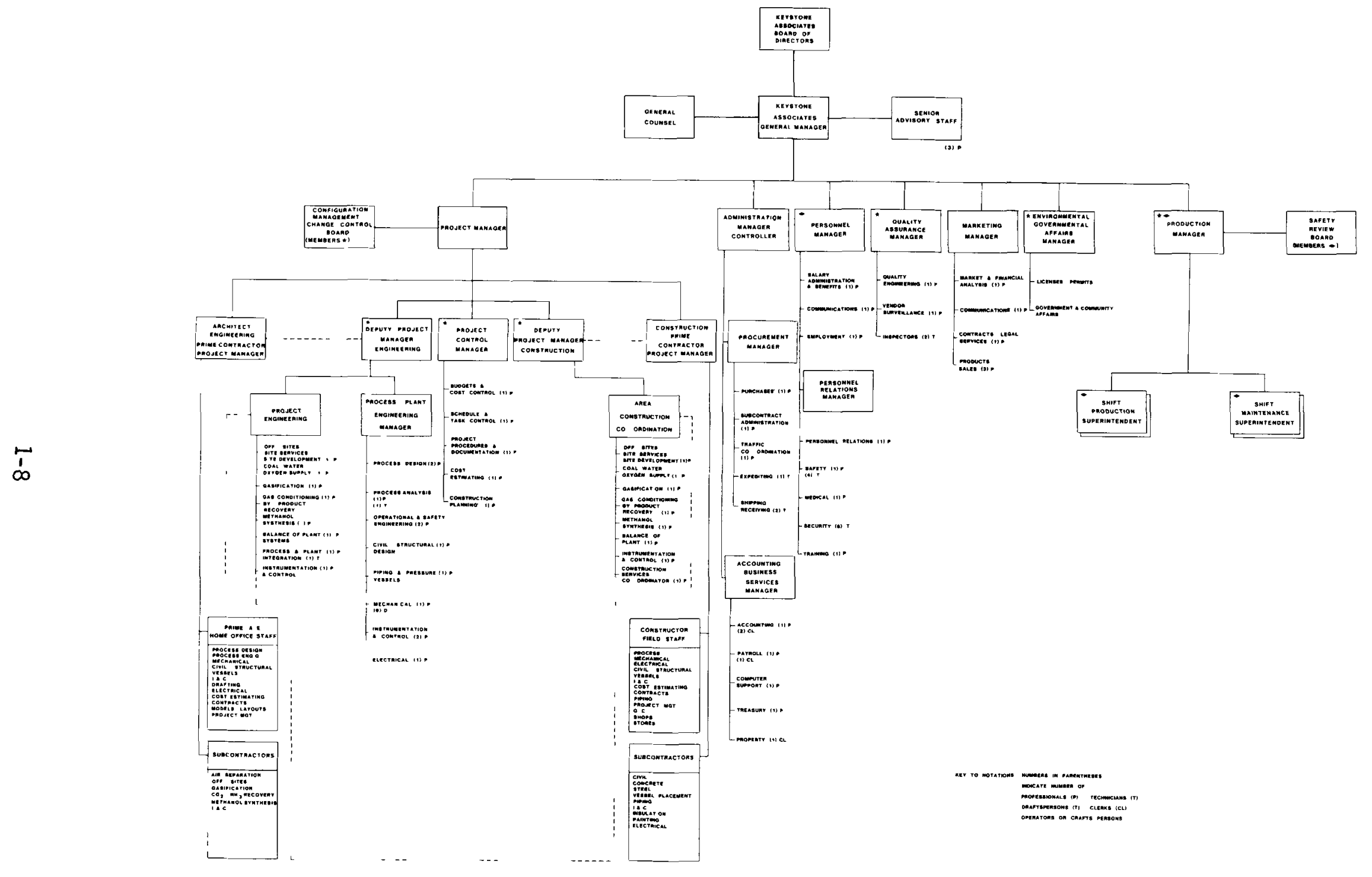

Figure 1.2-2 Plant Staffing Plan - Design and Construction Phase 
laborers. The numbers of personnel are designated on the Figure. The key management, professional and non-professional functions are briefly described below, according to the general nature of the activity, based on Figure 1.2-2.

\subsubsection{Engineering Design}

The Deputy Project Manager for Engineering is responsible to the Project Manager for Plant Design at the prime contractor's firm and at the home office of Keystone Associates. The Project Engineering Manager works with the architect/engineer, while the Manager of Process and Plant Engineering provides home office engineering support for design analysis, process design, operational and safety analysis and detailed engineering as required to support and guide the design activities of all contractor firms and meet all regulatory, technical and production requirements. The Project Control Manager provides budget and schedule control, procedures and documentation services, cost estimating and construction planning for the Project Manager.

\subsubsection{Construction}

Construction activities at the site will be managed through the Deputy Project Manager for Construction, who performs his functions through Area Coordinators, each responsible for a major plant subsystem. His ma in contact is with the construction prime contractor to insure that the design of the plant is properly implemented in the field.

\subsubsection{Production}

During the design and construction phase, the Production Manager and a small staff, consisting of Shift and Maintenance Superintendents, will be hired to insure that the design contains adequate provisions for safe, reliable and flexible operation. Initially, this group will begin drafting manuals and procedures for plant operations and maintenance. The group will also specify and procure required startup materials, spare parts, raw materials and support facilities, such as maintenance shops and stores.

$4071 \mathrm{E}$ 


\subsubsection{Administration}

Part of the administrative activities during the design and construction period will be performed by the Procurements Manager, who secures major subcontracts for services and supplies. The Accounting and Business Services Manager will perform the remainder of the administrative work including all accounting, treasury, payroll and business service functions for the firm, including computer support and property control.

\subsubsection{Personnel}

Personnel activities, such as hiring, employee communications, salary administration and benefits, will be handled by professionals reporting to the Personnel Manager. A Manager of Personnel Relations will be responsible for labor relations, safety, medical staff, training and plant security.

\subsubsection{Quality Assurance}

For the design and construction phase, the Quality Assurance Manager will have a small staff of professionals responsible for quality engineering and vendor surveillance. Some quality control functions, such as receiving inspection, will be performed. Later, this function will be expanded substantially to include product quality control, including inspection and analys is activities conducted within the $\mathrm{plant}$ and at the point of raw material receipt and product shipment.

\subsubsection{Marketing}

The chief activities of the Marketing Department during the design and construction period will be developing a methanol and by-product market, securing long-term contracts for product sales and performing continuing financial analyses to insure that the projected market remains a profitable bus iness for the firm. 


\subsubsection{Environmental and Government Affairs}

The design phase is an important one for the Manager of Environmental and Governmental Affairs. Required federal, state and local permits must be obtained before the start of construction. Therefore, attention to permitting activities, associated archaeological and air quality monitoring and erosion, dust and water discharge control will dominate during this phase. During plant construction, socioeconomic concerns could become critical. It will be essential to maintain close liaison with local citizen groups to insure that no adverse public reaction against plant construction develops and to insure support of local labor and civic organizations on whose support much of the ultimate project success rests.

\subsubsection{PRODUCTION PHASE ORGANIZATION}

The project organizational structure will change substantially during the last year of construction, as shown in Figure 1.2-3. Production people will be phased in early for training, and they will begin to take over systems as they are completed. The number of project management personnel will diminish until only a small engineering group remains when the production phase is in full operation. Given below are descriptions of key activity areas during the operation phase of the project.

\subsubsection{Engineering}

The Engineering Manager will have a small staff responsible for the design and implementation of $p$ lant modifications required to maintain production or otherwise improve production, efficiency, cost, reliability, safety performance or product quality. A Process and Plant Engineering Manager and a Project Services Manager will continue to support this technical function with engineering and drafting, project control services and related expertise. 


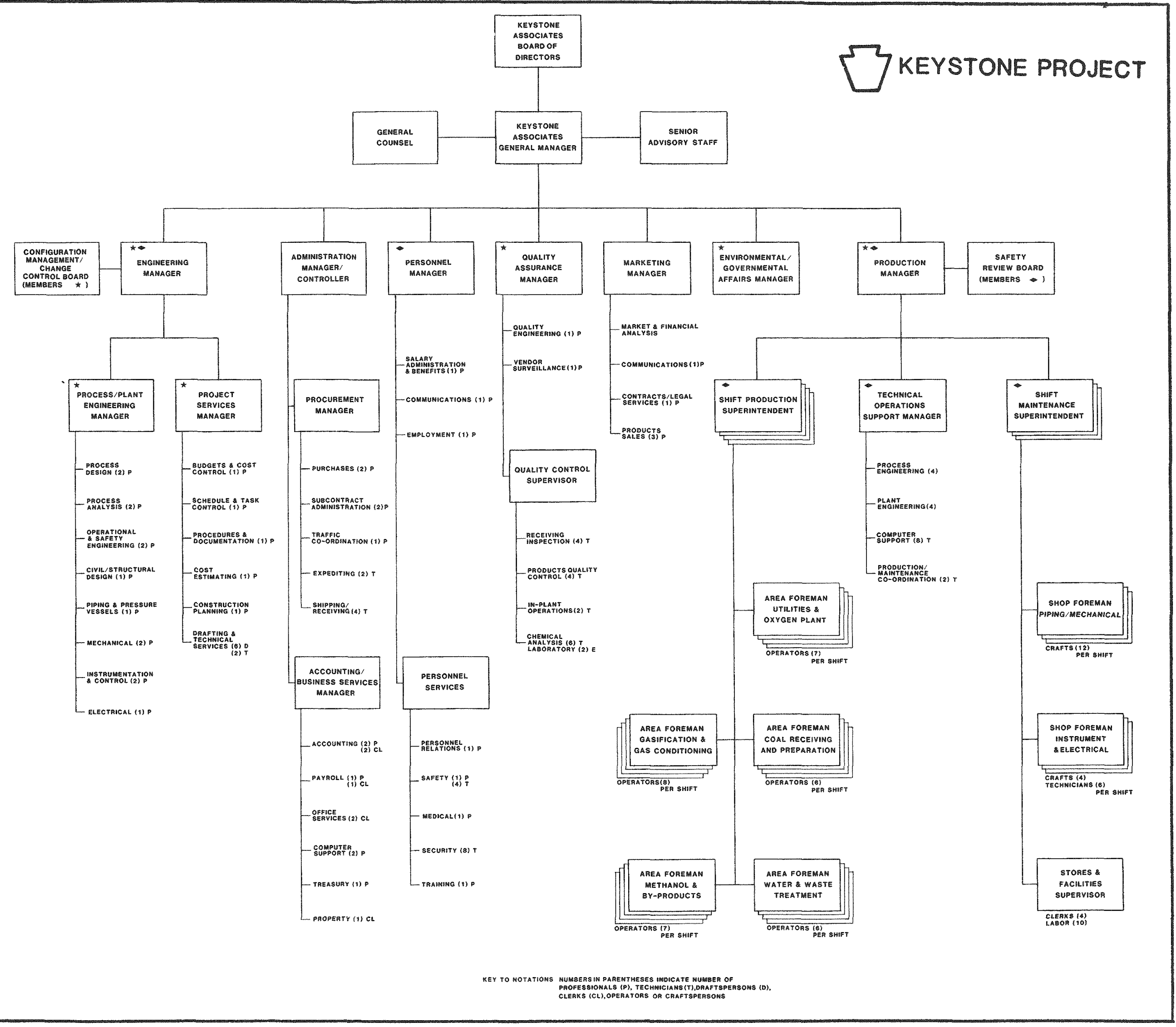

Figure 3-3 Organization Chart Production Phase 


\subsubsection{Administration, Personnel, Quality Assurance, Marketing and Environmental Activities}

The administration, personnel, quality assurance, marketing and environmental activities will be similar to those for the design and construction phase. Some of these activities will be enhanced as prime contractor personnel are phased out and their activities are assumed by the plant personnel organization of Keystone Associates. In particular, the quality control group, accounting group and personnel groups will add people to support the production staff.

\subsubsection{Production}

The Production Manager will function through Shift Superintendents, each of whom are responsible for all production operations during one of four around-the-clock shifts. Area foremen will report to the Superintendent. Each foreman will be responsible for operating a major plant subsystem, such as gasification or methanol synthesis, with a group of six to eight operators. Routine plant maintenance and minor construction and repair will be handled through Shift Maintenance Superintendents, each of whom is responsible for all shops and stores operations on each of three shifts (no weekend scheduled maintenance). Shop foremen supervise skilled craftspersons in the piping and mechanical, electrical and instrument, or storeroom areas.

More detailed job descriptions during the operation phase are being developed.

\subsubsection{STAFF ING PLAN}

The Keystone Project will provide adequate staff support to insure that all project and business objectives can be met with a minimum number of people so that overhead costs are controlled. The organizational charts, previously discussed, are consistent with this flexible staff plan. 
Table 1.2-1 is a year-by-year staffing $p l a n$, as currently envisioned, showing how each department increases or decreases for each type of personnel. The final column in the Table 1.2-1 represents the permanent staff that will exist during the production phase for the first module of the project.

This staffing $\mathrm{pl}$ an and the previous discussions on organizational function apply only for the first project module. In future years, as additional modules are added, the primary changes to the Management Plan will be to expand the project management function and to add additional production personnel. A different breakdown of plant operations would probably be made at that time to use trained people more effectively. In fact, as more modules are added, the number of personnel per plant output is expected to decrease as more efficient methods are learned and as support functions are spread over a larger production base. However, the present plan does not address the changes that will occur with subsequent module additions.

The staffing plan for the engineering and construction home office and for field activities is shown in Figure 1.2-4, along with those for the Keystone Associates plant organization. These curves show skilled field labor required in the construction phase, as well as engineers and technicians required for the design, construction and operation phases.

\subsection{TECHNICAL PLAN}

The success of a complex project like keystone depends on early definition of the tasks to be accomplished in order to establish the relationship of responsibility, work, schedule, budget and cost. The mechanism being used to achieve this for the Keystone Project is the Work Breakdown Structure (WBS). This section provides a brief description of the WBS:

(1) The second level (Summary Level) of the Keystone WBS

(2) The top level (Level I) logic developed from the WBS

(3) The associated Level I schedule of project tasks

(4) The budgets related to the project schedule. 
TABLE 1.2-1

YEAR-BY-YEAR STAFFING PLAN FOR THE KEYSTONE ASSOCIATES

PRODUCTION STAFF

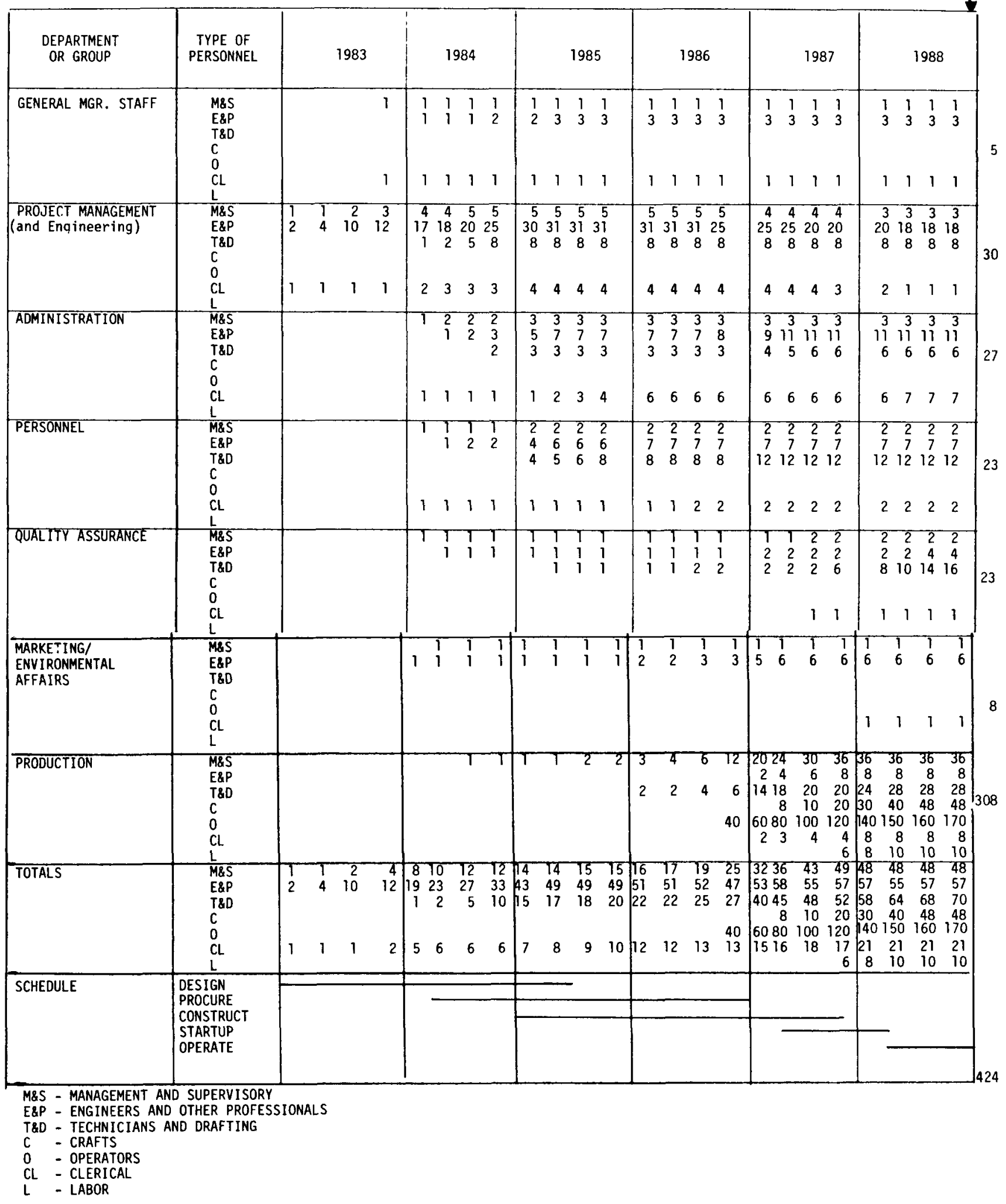




\section{\KEYSTONE PROJECT}

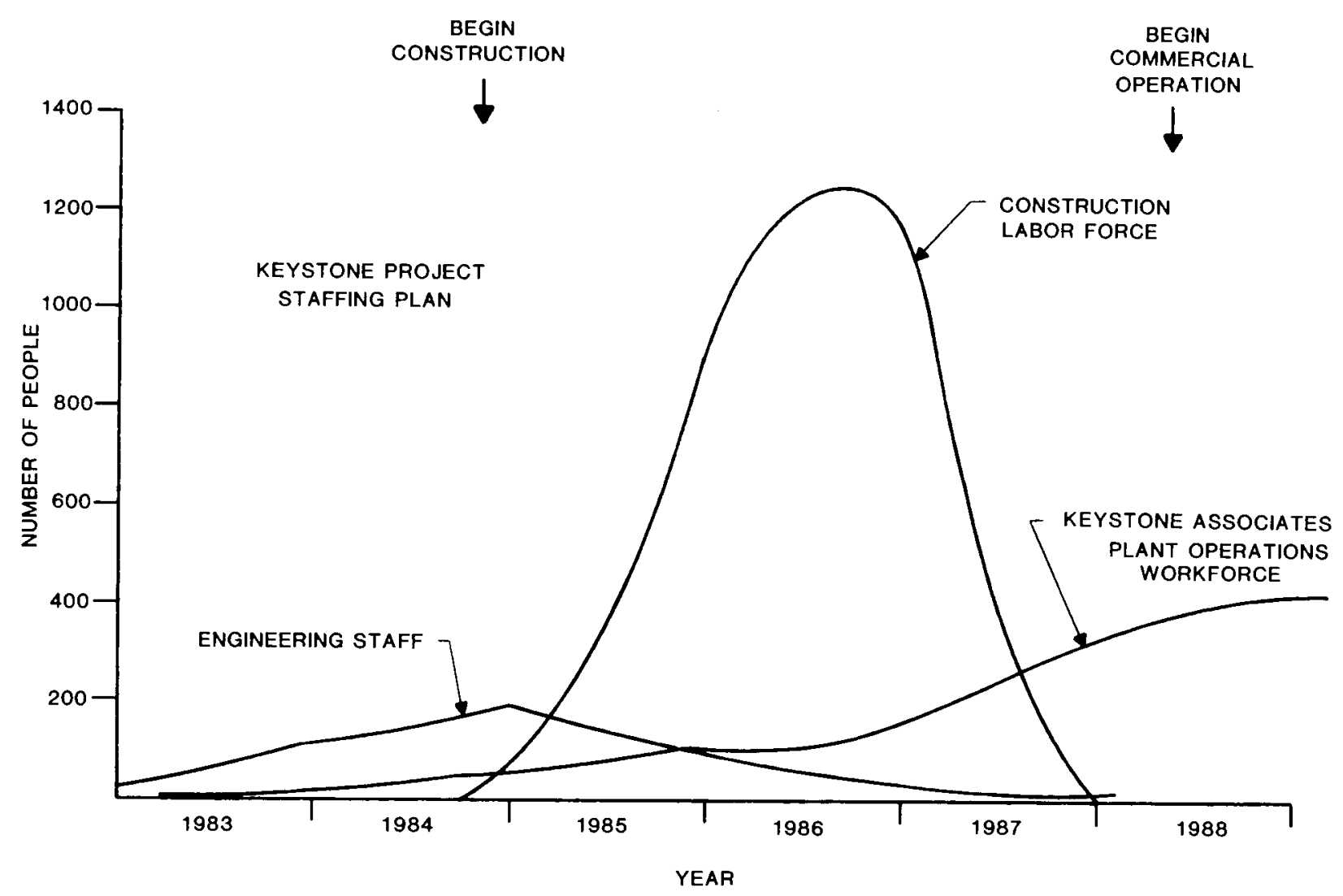

Figure 1.2-4 Project Staffing Plan 


\subsubsection{WORK BREAKDOWN STRUCTURE}

The WBS for the Keystone Project (Figure 1.3-1) is a product-oriented "family tree" of work packages that comprise all hardware, software, services and support elements necessary for successful completion of the project. This management technique allows for definition of tasks at various levels of detail for purposes of control and reporting. Table 1.3-1, presented at the end of Section 1.3, is a tabular presentation of the Keystone Project WBS that shows all elements to Level IV of the WBS ("0000," where the Keystone Project is at Level I). The Level II designations are grouped below for easy reference:

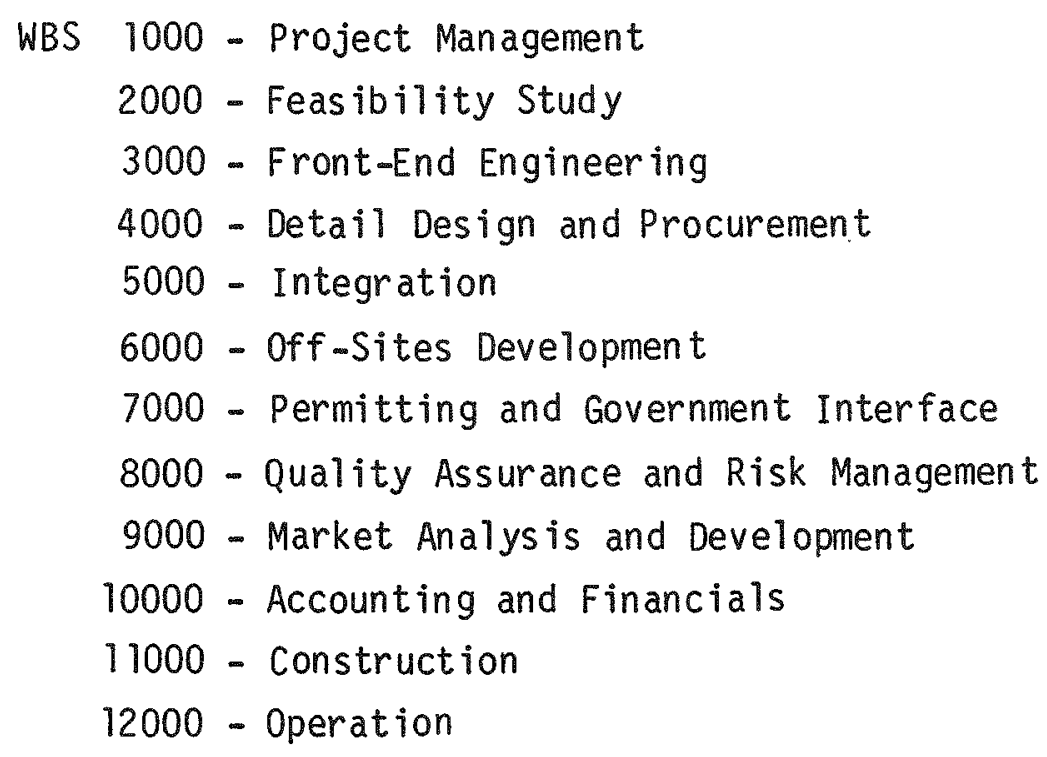

Level II of the WBS is the major summary level that organizes related tasks into logical groupings. Lower levels of the WBS represent a further breakdown of Level II elements and include specific reporting elements and management work packages. These lower levels identify a more detailed task definition and facilitate the orderly authorization of work in easily controllable segments.

The following discussion presents a description of each Level II WBS element. 


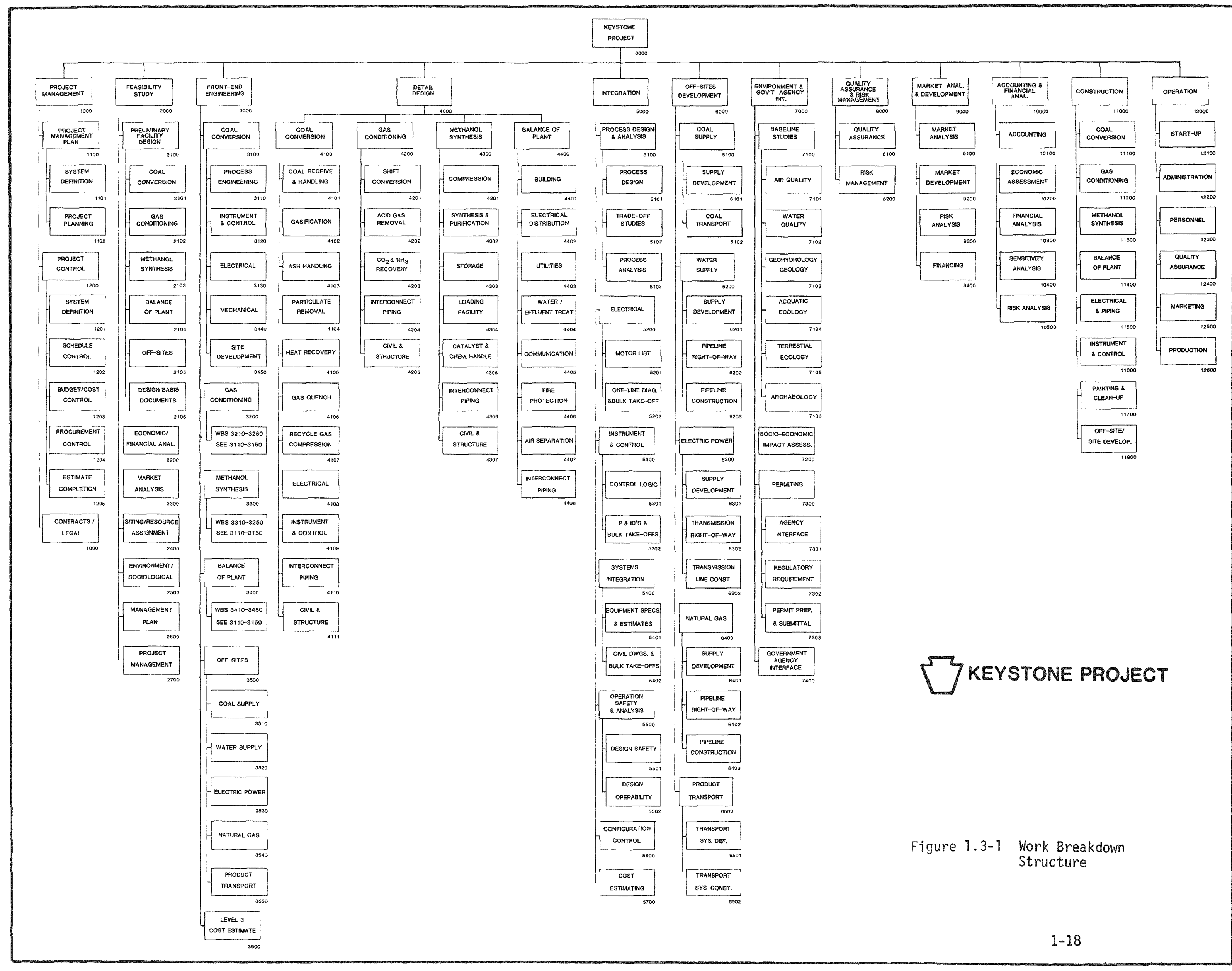




\subsubsection{Project Management - WBS 1000}

This element comprises all tasks required for planning, monitoring and controlling the Keystone Project. It is placed at Level II to stress its importance to success of the project and to assure independence from other technical tasks. The activities to be accomplished include maintenance of the WBS, development of procedures and plans, implementation of project control systems (schedule, budget, cost), administration of project contracts and legal support and maintenance of the total project cost estimate. This latter activity assures continuous visibility of the forecasted project cost.

\subsubsection{Feasibility Study - WBS 2000}

The tasks under this element have been completed. They were developed from the requirements defined by the Feasibility Study Grant, DOE Contract DE-FG01-81FE16122, and included:

- Preliminary Facility Design

- Economic and Financial Analysis

- Market Analysis

- Siting Evaluation and Resource Assessment

- Environmental, Health, Safety and Socioeconomic Assessments

- Project Management Plan

- Project Management

The technical work packages for the Feasibility Study served as the bas is for defining the technical systems, project licensability, markets and product cost for the project. The administrative elements used for management of the tasks in the Feasibility Study, including those of several major participants, will serve as the basis for the upgraded management systems for facility design and construction required under WBS 1000 .

$4071 \mathrm{E}$ 


\subsubsection{Front-End Engineering - WBS 3000}

This element has two purposes: (1) To assure that the engineer ing data needed for orderly completion of the permit applications are available when needed, and (2) to further develop the design, so that the capital and operating cost estimate will be accurate enough for the required management decisions, in August and December of 1983, on whether to proceed with the project. This element is the technical transition between the feasibility study preliminary design and the detail design phase (WBS 4000). Figure 1.3-2 shows the schedule of activities for this element.

\subsubsection{Detailed Design and Procurement - WBS 4000}

The work comprising this element is based on accomplishing WBS 3000 and provides all the design tasks needed for: (1) Total design, procurement and manufacture of all systems within the site boundary and (2) support for the permitting process. The cost accounts under this element will be further defined as the project moves toward this phase.

\subsubsection{Integration - WBS 5000}

The integration element provides the tasks necessary for assuring the following: (1) An optimum process design; (2) integration of on-site and off-site systems; (3) integration of all on-site systems; (4) configuration management; (5) operability, reliability and safety of all plant systems; and (6) development and maintenance of capital and operating cost estimates in support of the total project cost estimate.

\subsubsection{Off-Site Development - WBS 6000}

This element provides for four activities: (1) Identifying sources of $r a w$ materials meeting specifications defined under WBS 5000; (2) contracting for a reliable supply of resources; (3) contracting for transportation of the resources, including the development and construction of off-site transportation systems; and (4) design and construction of a reliable transportation system for transporting the product to market. 
1983 KEYSTONE PROJECT FRONT END ENGINEERING SCHEDULE

DESIGN AREAS

COAL CONVERSION
REFERENCE WBS 3100 REFERENCE WBS 3200

\section{METHANOL LYNTHESIS} BALANCE OF PLANT
REFERENCE WBS 3400
OFF-SITES \& SITE DEVELOPMENT
REFERENCE WBS REFENCE
3150

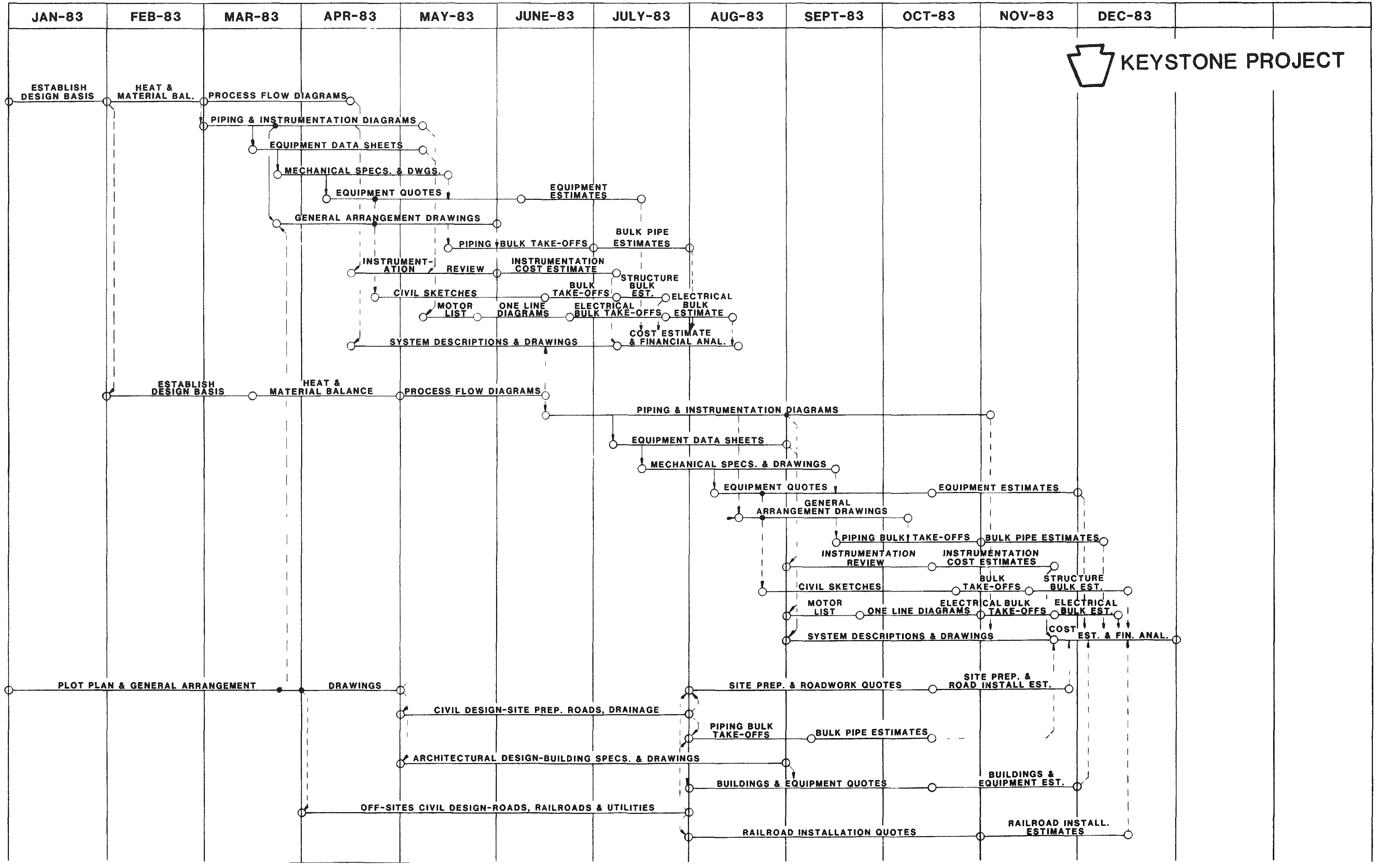

Figure 1.3-2 Schedule of Activities for WBS 3000 


\subsubsection{Environmental and Government Interface - WBS 7000}

The activities under this element are an extension and expansion of the environmental and permitting activities initiated during the Feasibility Study (WBS 2000). The resources provided will fulfill the requirements for collection of all environmental data; for the socioeconomic impact assessments; for the necessary permit applications; and for contacts with government agencies and the local community to assure complete and timely communications.

\subsubsection{Quality Assurance and Risk Management - WBS 8000}

This element provides the tasks needed to assure that quality requirements of the project are met and that potential risks are routinely identified, analyzed, monitored and mitigated. The element is placed at Level II of the WBS to assure a high level of visibility.

\subsubsection{Market Analys is and Development - WBS 9000}

The tasks of this element are a continuation of work initiated under WBS 2300 and include an analysis of the economic and market environment to assure that the Keystone Project retains a competitive position. Included in the tasks are development of customer and competitor files, development of pricing policies and monitoring of the potential for expanding the project's product mix. In addition, this element provides for securing necessary project financing.

\subsubsection{Accounting and Financial Analys is - WBS 10000}

This element provides for development and implementation of appropriate accounting systems, to assure timely and accurate financial planning, and collection of financial data and subsequent reliable reporting. This element also includes financial, risk and sensitivity analyses to provide management with up-to-date assessments of the project status. These analyses result from data developed under WBS 1000 (Project Management) and WBS 9000 (Market Analys is and Development), as well as this work element, and they support the risk management function of WBS 8000 . 


\subsubsection{Construction - WBS 11000}

This element provides the resources required for construction and construction management of all site development, site facilities and off-site interfacing. Specific accounts are to be formulated as construction requirements are developed under WBS 4000 through 7000 .

\subsubsection{Operation - WBS 12000}

This element provides for a11 labor, materials and services needed for $p l a n t$ startup and continued commercial operation.

\subsubsection{PROJECT LOGIC NETWORKS}

The Project Level I Logic Diagram (Figure 1.3-3) is a top level logic network that graphically displays the overall Project objectives and identifies the major relationship among the top level WBS elements. This schedule incorporates all significant project milestones and activities and serves as the basis for controlling lower level schedules (see Level II Logic, Figure $1.3-4)$.

By comparing the two levels of logic, it can be seen that greater levels of detail for each succeeding level support the higher level, controlling schedules as well as WBS objectives. This approach to scheduling increases the flexibility available to cost account managers in managing their WBS elements without sacrificing control at higher levels of the WBS.

\subsubsection{PROJECT SCHEDULES}

While the use of Project Logic Networks assures that proper constraints and interfaces are identified and controlled, such networks tend to be overly complex for day-to-day management of tasks. The Keystone Project, therefore, uses a simplified bar chart schedule, developed from the Logic Networks, for management purposes. Figure 1.3-5 shows a Level I schedule, developed from the Level I logic. 


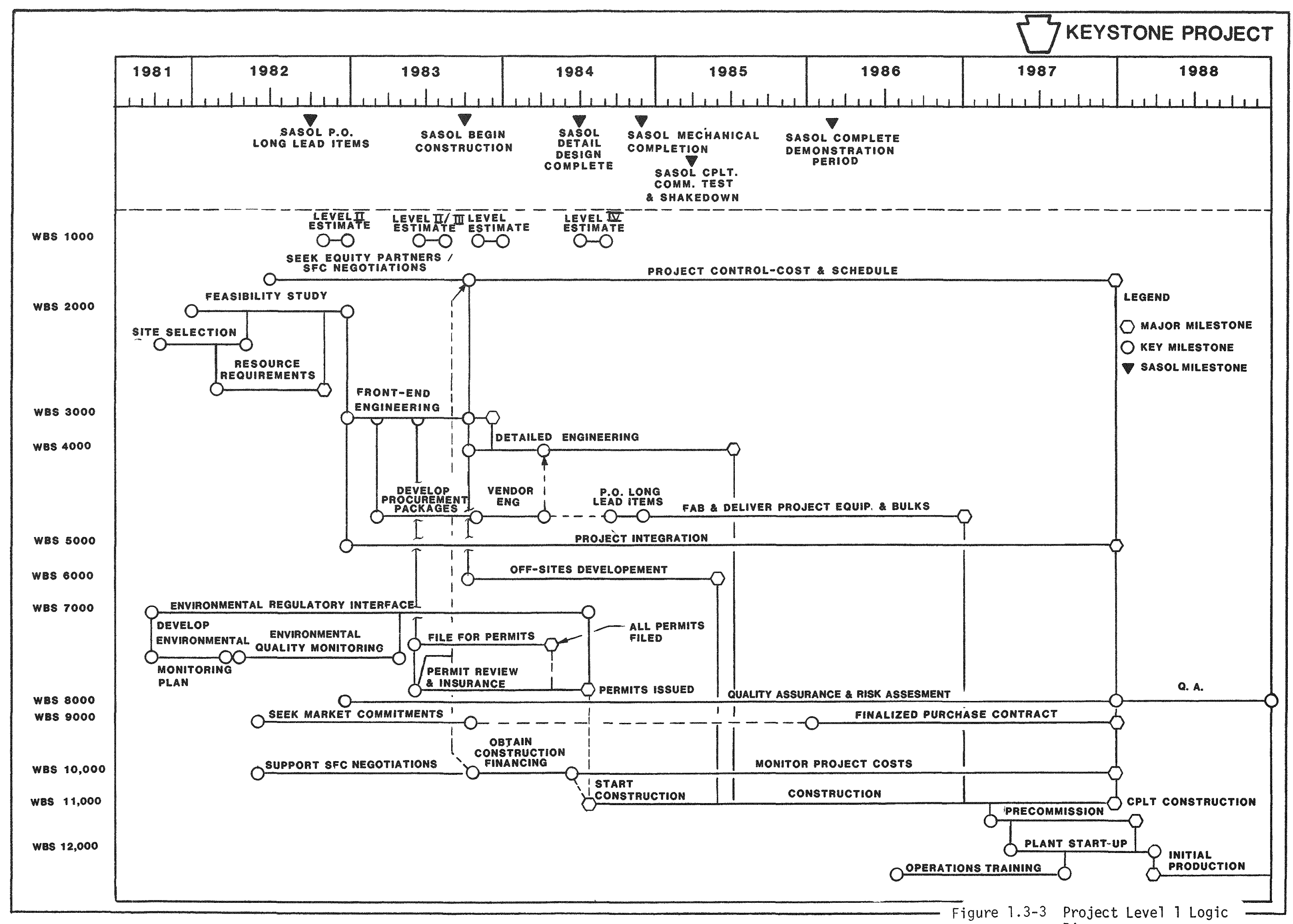

Figure 1.3-3 $\begin{array}{r}\text { Project } \\ \text { Diagram }\end{array}$ 


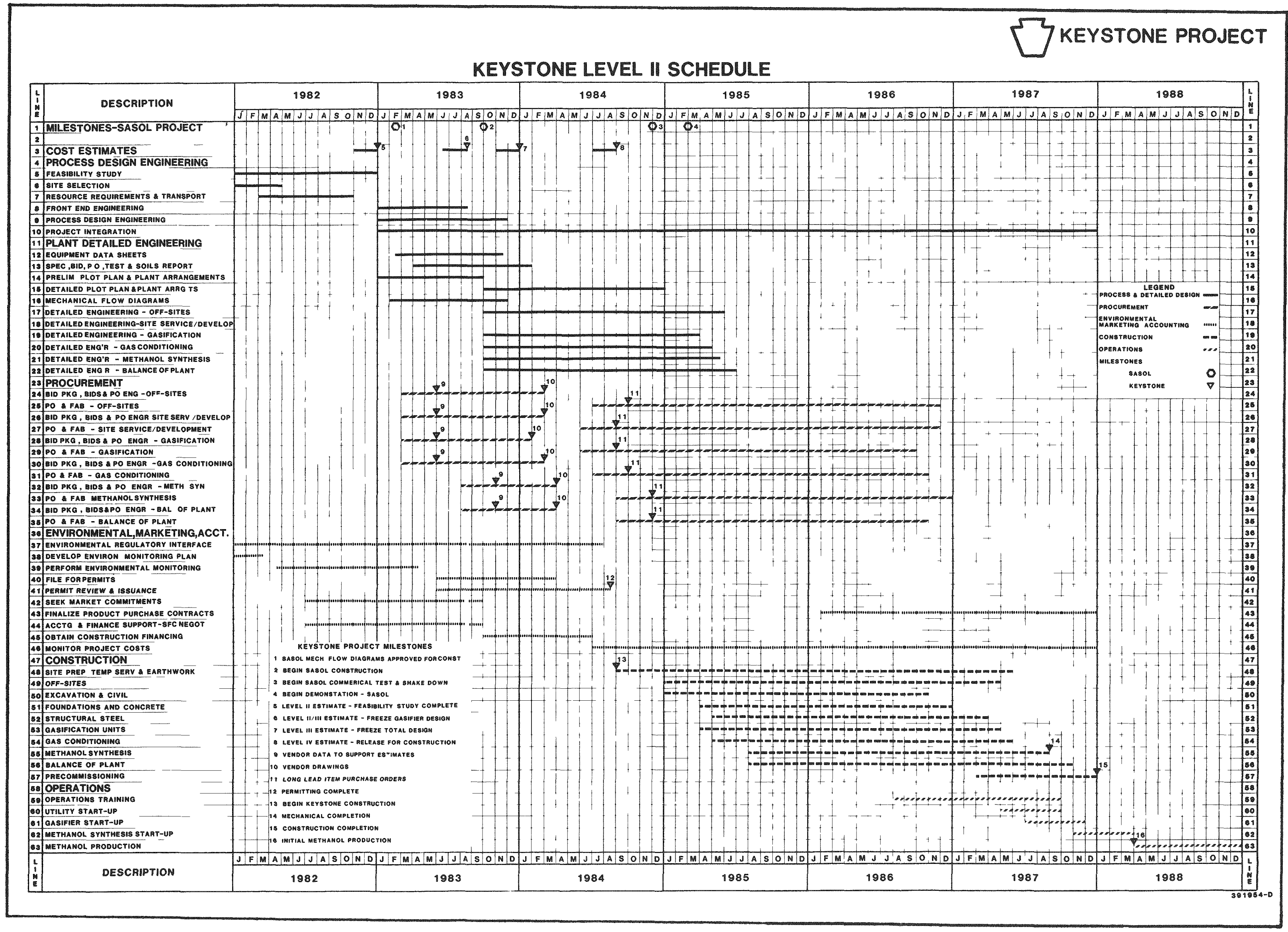

Figure 1.3-4 Level II Project 
The major decision points are incorporated into the major milestones identified in Figure $1.3-5$ and comprise the following:

- Feasibility Study Complete - At this point, a decision is made on whether or not to continue with the project.

- Level II/III Estimate - At this point, project areas having the greatest technical risk will have been developed in sufficient detail (i.e., Level III) so that a decision can be made on whether to proceed with a detailed design that results in the project reaching a Level III cost estimate.

- Level III Estimate - At this point, the design for the total project has progressed to within \pm 15 percent cost accuracy (i.e.s Level III). A decision must be made on whether to place major equipment purchase orders (Milestone 8).

- Level IV Estimate - This decision point coincides with or follows the receipt of all major permits. At this point, a decision is made on whether to proceed with construction (Milestone 9).

Figure 1.3-5 shows that the preconstruction phase is initiated with front-end engineering in January 1983 and continues into the detail design phase in October 1983. Construction activities at the site begin in September 1984. Engineering will have proceeded beyond the level necessary to initiate construction during the first half of 1984. However, construction will not begin until all permits are received. Construction continues through 1987 , with mechanical completion occurring during September 1987, and the completion of precommissioning during December 1987. Startup is phased with mechanical completion and check-out beginning May 1987 and ending March 1988. Commercial production is scheduled to begin April 1988. Figure 1.3-5 is a Level II schedule that gives greater definition of the activities summarized above. 


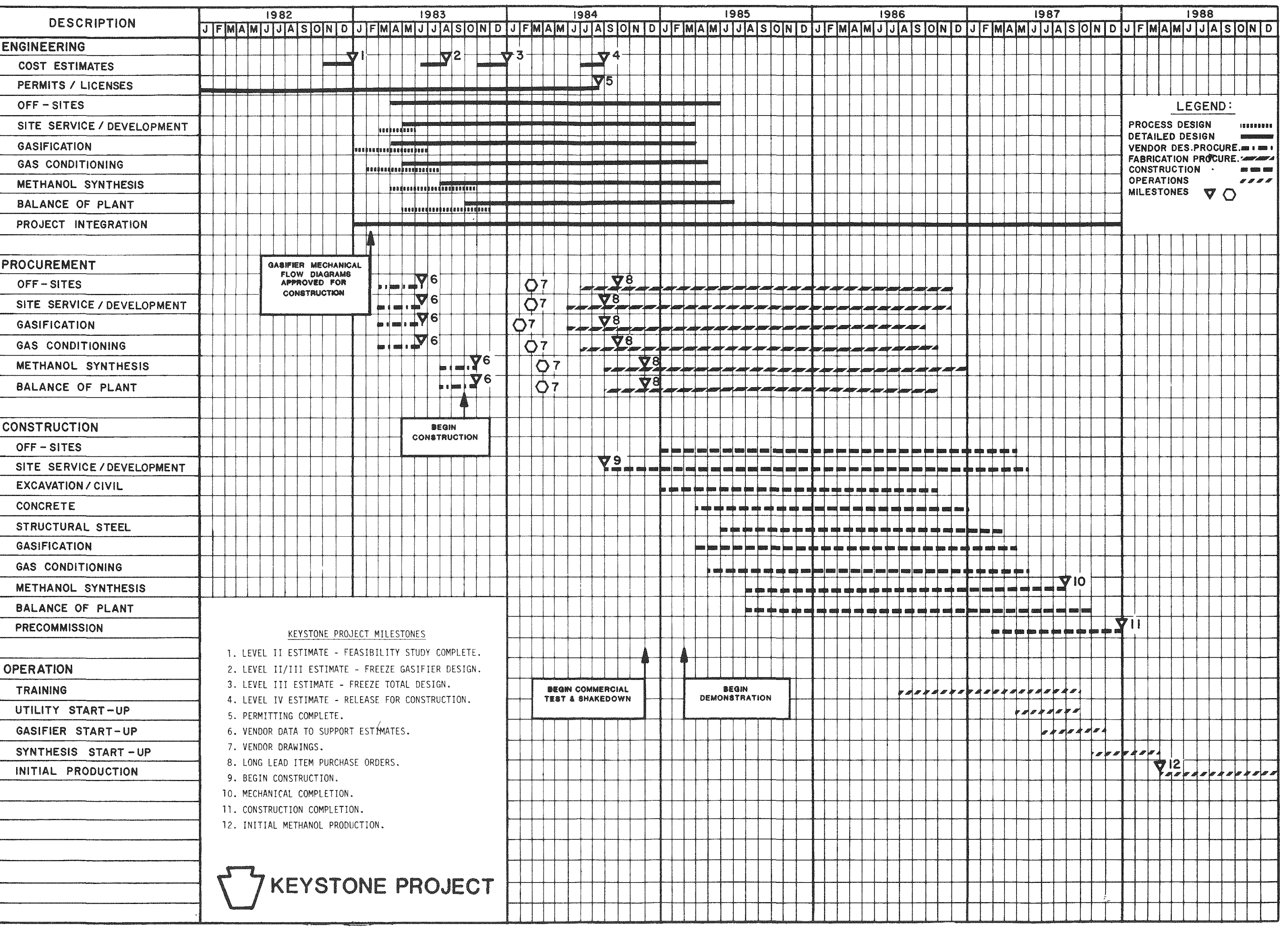

Figure 1.3-5 Overall Keyston Project Schedule 
TABLE 1.3-1

KEYSTONE PROJECT WORK BREAKDOWN STRUCTURE

WBS Element

0000 Keystone Project

1000 Project Management

1100 Project Management P Ian

1101 System Definition

1102 Project Planning

1200 Project Control

1201 System Definition

1202 Schedule Control

1203 Budget/Cost Control

1204 Procurement Control

1205 Estimate to Completion

1300 Contracts/Lega 1

2000 Feasibility Study

2100 Preliminary Facility Design

2101 Coal Conversion

2102 Gas Conditioning

2103 Methanol Synthes is

2104 Balance of Plant

2105 Off-Sites

2106 Design Bas is Documentation

2200 Economic and Financial Analysis

2300 Market Analys is

2400 Siting Evaluation and Resource Assessment

2500 Environmental, Health, Safety and Socioeconomic Assessments

2600 Project Management Plan

2700 Project Management 
TABLE $1.3-1$

(cont inued)

3000 Front-end Engineering

3100 Coal Conversion

3110 Process Engineering

3111 Heat and Material Balance

3112 Process Flow Diagrams

3120 Instrumentation and Control Engineer ing

3121 Piping and Instrumentation Diagrams

3122 Piping and Instrumentation Bulk Take-offs

3123 Instrument and Control Review

3130 Electrical Engineering

3131 Motor List

3132 One-line Diagrams

3133 Electrical Bulk Take-off

3140 Mechanical Engineering

3141 Equipment Specifications

3142 Equipment Quotes

3150 Site Development

3151 P lot $P 1$ an and General Arrangements

3152 Civil/Structural Bulk Take-offs

3200 Gas Conditioning

3210 - 3250 (see WBS 3110-3150)

3300 Methanol Synthes is

3310 - 3350 (see WBS 3110-3150)

3400 Balance of Plant

3410 - 3450 (see WBS $3110-3150$ )

3500 off-sites

3510 Coal Supply

3520 Water Supply

3530 Electric Power

3540 Natural Gas

355C Product Transport

3600 Level III Estimate 
TABLE 1.3-1

(continued)

4000 Detail Design and Procurement

4100 Coal Conversion

4101 Coal Receiving and Handling

4102 Gasification

4103 Ash Handling

4104 Particulate Removal

4105 Heat Recovery

4106 Gas Quench

4107 Recycle Gas Compression

4108 Electrical

4109 Instrumentation and Control

4110 Interconnecting Piping

4120 Civil and Structures

4200 Gas Conditioning

4201 Shift Conversion

4202 Acid Gas Removal

$4203 \mathrm{CO}_{2}$ and $\mathrm{NH}_{3}$ Recovery

4204 Interconnecting Piping

4205 Civil and Structures

4300 Methanol Synthes is

4301 Compression

4302 Synthes is and Purification

4303 Storage

4304 Loading Facility

4305 Catalyst and Chemical Handling

4306 Interconnecting Piping

4307 Civil and Structures

4400 Balance of Plant

4401 Buildings

4402 Electrical Distribution

4403 Utilities

4404 Water/Effluent Treatment and Disposal

4405 Communications 
TABLE $1.3-1$

(cont inued)

4406 Fire Protection

4407 Air Separation

4408 Interconnecting Piping

5000 Integration

5100 Process Design and Analys is

5101 Process Design

5102 Trade-off Studies

5103 Process Analys is

5200 Electrical

5201 Motor List

5202 One-line Diagrams and Bulk Take-offs

5300 Instrument and Control

5301 Control Logic

5302 Piping and Instrument Diagrams and Bulk Take-offs

5400 Systems Integration

5401 Equipment Specifications and Estimates

5402 Civil Drawings and Bulk Take-offs

5500 Operation Safety and Analys is

5501 Design Safety Reviews

5502 Design Operability Reviews

5600 Configuration Control

5700 Cost Estimating

6000 Off-Sites Development

6100 Coal Supply

6101 Supply Development

6102 Coal Transport

6200 Water Supply

6201 Supply Development

6202 Pipe Line Right-of-Way

6203 Pipe Line Construction 
TABLE 1.3-1

(cont inued)

6300 Electrical Power

6301 Supply Development

6302 Transmission Right-of-Way

6303 Transmission Line Construction

$6400 \quad$ Natural Gas

6401 Supply Development

6402 Pipeline Right-of -Way

6403 Pipeline Construction

6500 Product Transport

6501 Product Transport System Definition

6502 Product Transport System Construction

7000 Environmental and Government Agency Interface

7100 Baseline Studies

7101 Air Quality

7102 Water Quality

7103 Geohydrology and Geology

7104 Aquatic Ecology

7105 Terrestial Ecology

7106 Archaeology

7200 Socioeconomic Impact Assessment

7300 Permitting

7301 Agency Interface

7302 Regulatory Requirement Identification

7303 Permit Preparation and Submittal

7400 Government Agency Interface

8000 Quality Assurance and Risk Management

8100 Quality Assurance

8200 Risk Management 


\section{TABLE $1.3-1$}

(cont inued)

9000 Market Analys is and Development

9100 Market Analys is

9200 Market Development

9300 Risk Analys is

$9400 \quad$ Financing

10000 Accounting and Financial Analys is

10100 Accounting

10200 Economic Assessments

10300 Financial Analys is

10400 Sensitivity Analys is

10500 Risk Analys is

11000 Construction

11100 Coal Conversion

11200 Gas Conditioning

11300 Methanol Synthes is

11400 Balance of $P$ lant

11500 Electrical and Piping

11600 Instrument and Control

11700 Paint and Cleanup

11800 off-sites Integration and Site Development

12000 Operation

12100 Startup

12200 Administration

12300 Personnel

12400 Quality Assurance

12500 Marketing

12600 Production 


\subsection{PROJECT CONTROL SYSTEM}

This section describes a Project Control System that will assist management meet all technical and financial objectives. Parts of the system have been and are being implemented, and most of the system will be in place by the second quarter of 1983.

Management of the Keystone Project is based on an integrated system of planning and control that assures the following:

- Effective integration of work descriptions, schedules and budgeted and actual costs

- Objective assessment of work accomplished measured against budgeted costs and schedule

- Effective, timely reporting of work accomplished measured against budgeted costs and schedule

- A sound basis for continuously updating estimates to completion

- Ready access to and traceability of supporting detail through a well-defined, task-oriented work breakdown structure

- Effective management of critical or high-risk project areas

- Technical controls.

Fundamental to this control system is the organization of work, budgets and schedules around the Work Breakdown Structure (WBS), discussed in Section 1.3, and the establishment of technical, budgetary and schedule baselines. Changes to approved baselines are systematically controlled, and audit trails are maintained.

The initial step in implementing the Keystone Project's management system was to define the tasks to be performed using the WBS. Responsibility for performance of the work is being assigned to the appropriate organizations within the project structure. The responsible organizations will then refine the upper level WBS elements (summary cost accounts and/or cost accounts) into appropriate work packages. This detailed analys is of tasks forms the lowest 
level of the WBS and provides support for the upper level plans, schedules and estimates. Traceability from the highest level of the WBS (total project) to the lowest level (work packages) is therefore assured.

\subsubsection{SCHEDULING SYSTEM OVERVIEW}

The Critical Path Method (logic networking) is the primary means of planning, monitoring and reporting schedule progress. Development, design, licensing, fabrication, construction, and testing are integrated into the project schedule.

Project milestones are being developed for the summary cost accounts at Level II of the WBS to serve as the basis for planning cost accounts. During the early stages of the project, the Level I logic network (Figure 1.3-3) was developed to define the overall program objectives and identify the interrelationships of project participants. This network incorporates the project milestones and identifies significant events or activities. The schedule was reviewed and approved by all participants. It serves as the baseline for evaluating more detailed schedules developed by participants and for allocating time-phased budgets for Level II WBS elements. Organizations with task performance responsibilities develop further schedule details that are then interfaced as Level II logic networks.

Level II networks are intermediate planning logic diagrams related directly to the Level II schedule and the intermediate levels of the WBS. These networks display near-term and far-term planning by each participant with enough detail to show task life span and the logic and interdependencies of activities and participants. Major milestones and interfaces are identified on the Level II network and serve as measures of schedule progress.

Near-term detail logic networks (Level III) may be developed at the lowest level of the WBS for selected critical or high-risk tasks to assure a complete definition of requirements. Management monitors these schedules closely to detect potential problems early. Plans can then be developed to mitigate potential risks. 


\subsubsection{Schedule Control}

Schedule control is used at the lowest level of project authority consistent with the level and purpose of the schedule. For example, detail (Level III) schedules may be revised by the responsible organization, consistent with formal established procedures, if Level II schedule logic, project control milestones or authorized budgets are not affected. If any of the above items are affected, approval for revision to schedules is handled by the Project Configuration Management/Change Control Board. All authorizations for schedule changes are documented to assure traceability from one level of schedule to another and to provide an audit trail for revisions to tasks (WBS), budgets and deliverables.

\subsubsection{TOTAL PROJECT COST ESTIMATE}

The current total project cost estimate, established in the Keystone Project Feasibility Study, has been developed at Levels III and IV of the WBS. Each project participant's scope of work and schedule were analyzed, and estimates were formulated for each item of major equipment, bulks, labor and services. The estimates reflected the quantities required, the time-phasing of effort and the manufacture and installation of all items. The estimates at the lower WBS levels were grouped, producing a summary-level, time-phased estimate that shows the total cost of plant investment, development and operation. The estimate was reviewed and approved by project management and serves as the baseline total project cost estimate that is being used in current financial studies for the project.

\subsubsection{Total Project Cost Estimate Control}

The total project cost estimate will be recorded to reflect all authorized changes in project plans and requirements. Each change will be documented with sufficient data to explain the nature of and reasons for the adjustment, impact values and other pertinent data. This documentation will be the basis for presenting the change to the Change Control Board and will provide the necessary audit trail. All changes to the total project cost estimate must be authorized by the Change Control Board. 


\subsubsection{FINANCIAL CONTROL}

The financial systems provide control of budgeted expenditures, estimates and contingency and incurred costs. These systems operate in conjunction with the total project cost estimate (Section 1.4.2) to assure financial control as the project progresses. Budgeting is based on the time-phased cost estimates in order to provide comparative data between estimates and budgets. Information on actual financial performance for the current period is also considered in the maintenance of long-term cost controls. Use of both the financial control systems and the total project cost estimate assures that long-term financial objectives are translated into specific near-term operations and are incorporated into the instruments used to estimate the cost of the Keystone Project over its entire life.

\subsubsection{Budget Development}

Budget allocation amounts are determined based upon two considerations: (1) The total project cost estimate for each fiscal year in year-of-expenditure dollars, and (2) the associated scheduled work. The responsible project organization further refines the budget allocation by developing summary cost accounts, cost accounts, and/or work packages, depending on the level at which the budget allocation is made. Each budget is defined in terms of scope and schedule. All plans identify measurable milestones so that a determination can be made of progress versus budget. Figure 1.4-1 shows the Cost Account Planning and Reporting (CAPR) forms used in the Keystone Project planning process.

\subsubsection{Management Reserve}

Contingencies will be controlled by means of a cost account held by the Project Manager. The account provides for a management reserve that is made available to cover unforeseen project costs. Access to the reserve is through authorization by the Configuration Management/Change Control Board upon presentation of sufficient information to justify an increase in budget. Underruns for specified tasks are incorporated into the management reserve for reallocation as required.

$4071 E$ 
WBS ELEMENT

NO.

TITLE

SCOPE OF WORK/REQUIREMENTS cost ACCOUNT No.

\section{CONSTRAINTS}

APPROVALS

Figure 1.4-1 Cost Account Planning and Reporting (CAPR)

Forms - Keystone

Project (Sheet 1 of 3 ) 
SYNTHETIC FUELS DIVISION

COST ACCOUNT PLANNING \& REPORTING FORM - CAPR

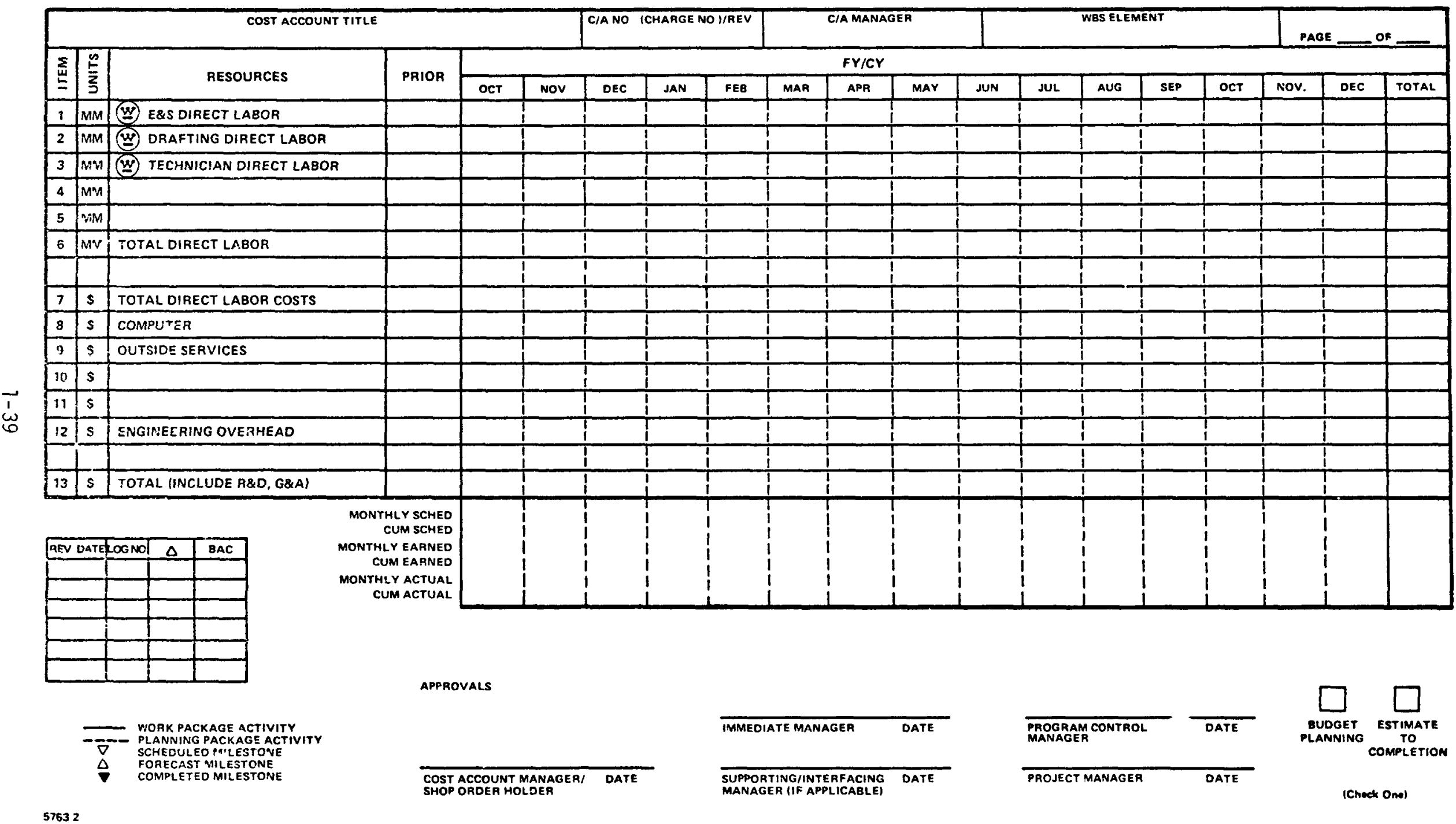

Figure 1.4-1 (Continued)

(Sheet 2 of 3 ) 
SYNTHETIC FUELS DIVISION

COST ACCOUNT PLANNING \& REPORTING FORM - CAPR

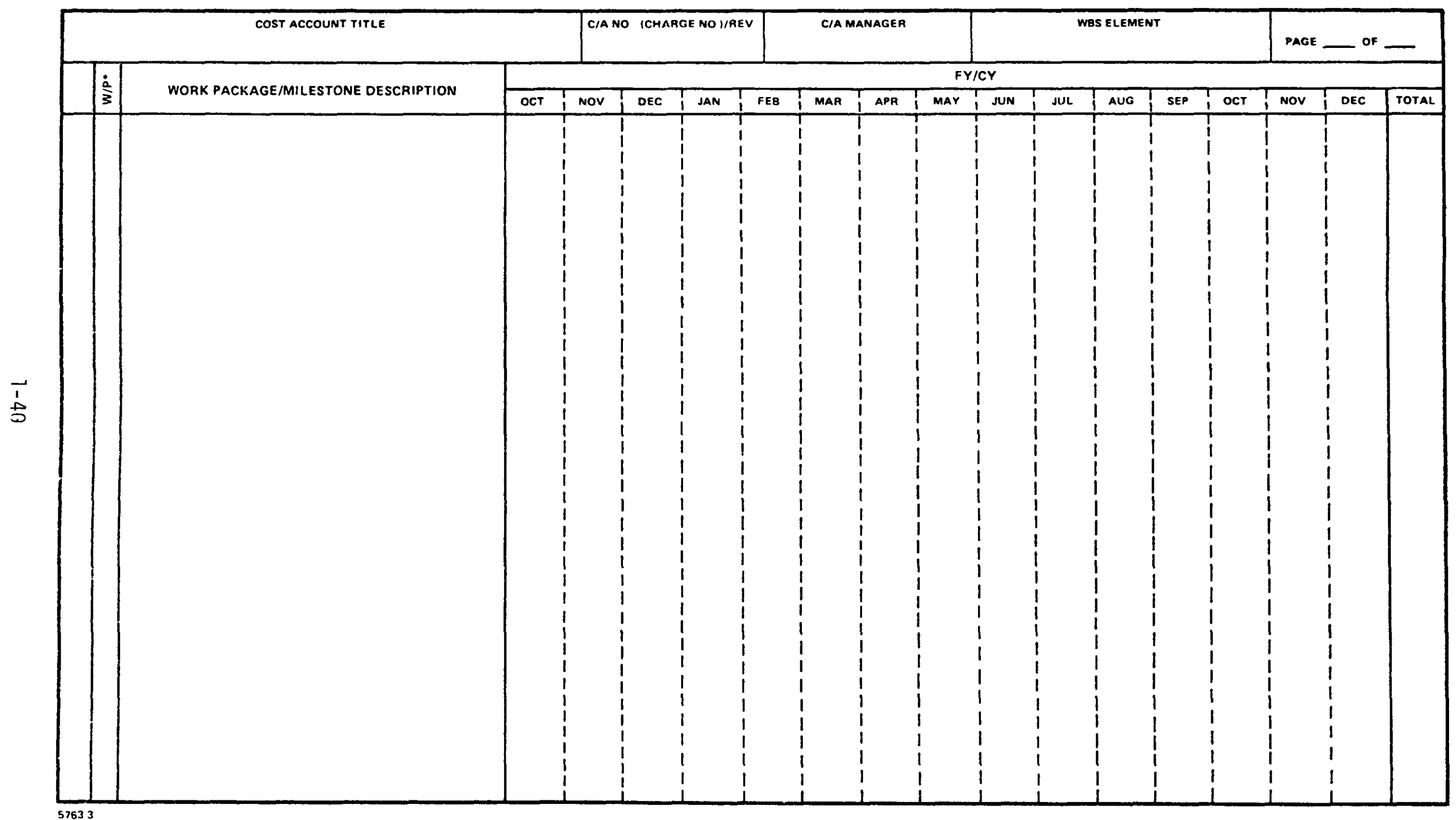

Figure 1.4-1 (Continued)

(Sheet 3 of 3 ) 


\subsubsection{Financial Planning}

The annual financial $\mathrm{plan}$ is developed and used by project financial management to measure total project financial performance during each fiscal year. The financial plan is based on the fiscal year budget, as defined by the total plant cost estimate, and is prepared by each project participant to identify planned monthly expenditures. This $p l a n$ is then used as the mechanism for monitoring actual and/or accrued cost on a monthly basis.

\subsubsection{Budget and Financial Plan Maintenance}

Project fiscal year budgets and financial plans are updated during the year under two conditions: (1) If major changes in project work scope, schedule or organizational responsibility occur, and (2) at scheduled general mid-year reviews of progress, incurred costs or accrued costs that result in changes to budgets and/or financial plans.

Budget reallocation authority will be established at appropriate levels of the project organization to permit flexibility in responding to required changes without sacrificing controls.

Each project participant may establish and control a management reserve account to facilitate changes within established scopes and budgets. Significant changes, for example, may be necessary as a result of approved engineering change notices. When the reallocation is within the participant's reallocation authority and does not exceed their management reserve, the participant may revise their budget. All changes must be documented to describe the nature of the change, the justification and the dollar amount to assure traceability from established baselines.

\subsubsection{Actual Financial Data Accumulation, Analys is and Reporting}

Each project participant will establish systems that provide for the collection of costs attributed to specific cost accounts. Each participant will provide financial data, as both actual and accrued costs, to project 
financial management each month. Monthly expenditures and commitments will be analyzed relative to $p l a n n e d$ monthly spending, fiscal year-to-date, total project-to-date and forecast of cost-to-completion.

In addition to reported costs, each participant will prepare narrative analyses of significant variances, explaining the variance and defining the potential impact of the variance on the authorized budget and/or the total project cost estimate. Potential problems can be identified, and management action can be taken to mitigate the risk of overrun.

\subsubsection{TECHNICAL CONTROL}

A formal project design guideline is being developed, based on design conclusions reached in the recently completed DOE feasibility study, and will be issued as the "Keystone Project Specification." This document will describe the requirements and constraints necessary to assure that each project participant can carry out the engineering, procurement and construction activities needed to build a facility meeting specified performance requirements. This design document will be controlled at the top level. Changes to controlled design documents, once baselined, will require the approval of the Configuration Management/Change Control Board.

Based on requirements in the Project Specification, process performance will be described in a process specification, which will be the basis for system design descriptions. These descriptions are comprehensive design documents that specify system requirements, including the design, operation and maintenance for the various systems that comprise the total facility. These documents are the basis for equipment specifications, engineering drawings and operating and maintenance procedures. These system design descriptions also control system-to-system interfaces.

The equipment specifications and drawings are the next lower tier of project design documents. Equipment specifications are required for all engineered components within a system and set forth all the specific requirements and conditions for the procurement or manufacture of equipment and/or services. For non-engineered components, equipment data sheets serve the same role as the equipment specification. 
Design data necessary for the development of a design, but not contained in a specific controlled design document, are transferred among project participants through Data Information Sheets (DIS). An example of a DIS cover sheet is shown in Figure 1.4-2. Information in a DIS does not contain data that belongs in one of the higher, tier design documents that are subject to design control. Use of the DIS information will be limited to a specified application by a specified receiver only. Authorization for use will be indicated by a signature of the manager responsible for the transmitted data.

The design review is used to verify the design baseline defined in the controlled design documents. These are formal reviews held on major systems, subsystems and equipment and are scheduled on the Level II schedule by each of the project participants. During a review, the design is compared with requirements to assure that the design meets process requirements and is safe, operable, inspectable, maintainable and cost-effective. Review of the design while the design is evolving helps lessen the technical, safety, operability and cost risks.

Technical control is established early in the design process by baselining of the Project Specification, and subsequently the lower tier documents, and is maintained as the design evolves through change control procedures. The Engineering Change Notice (ECN) is the mechanism for documenting proposed changes.

\subsubsection{Configuration Management}

Configuration management is the systematic evaluation, coordination and approval or disapproval of all proposed changes in the project that depart from established baselines. The process includes verification that approved changes are incorporated into the technical documentation, the manufactured item and the installed system. This activity will be initiated during the design phase and remain in place through manufacture, installation and operation of equipment and systems. (See Figure 1.4-3 for a schematic portrayal of the system.) All changes to approved baselines will be documented with specific data to explain the nature of and reasons for the change, other pertinent technical information and impacts on schedule and 


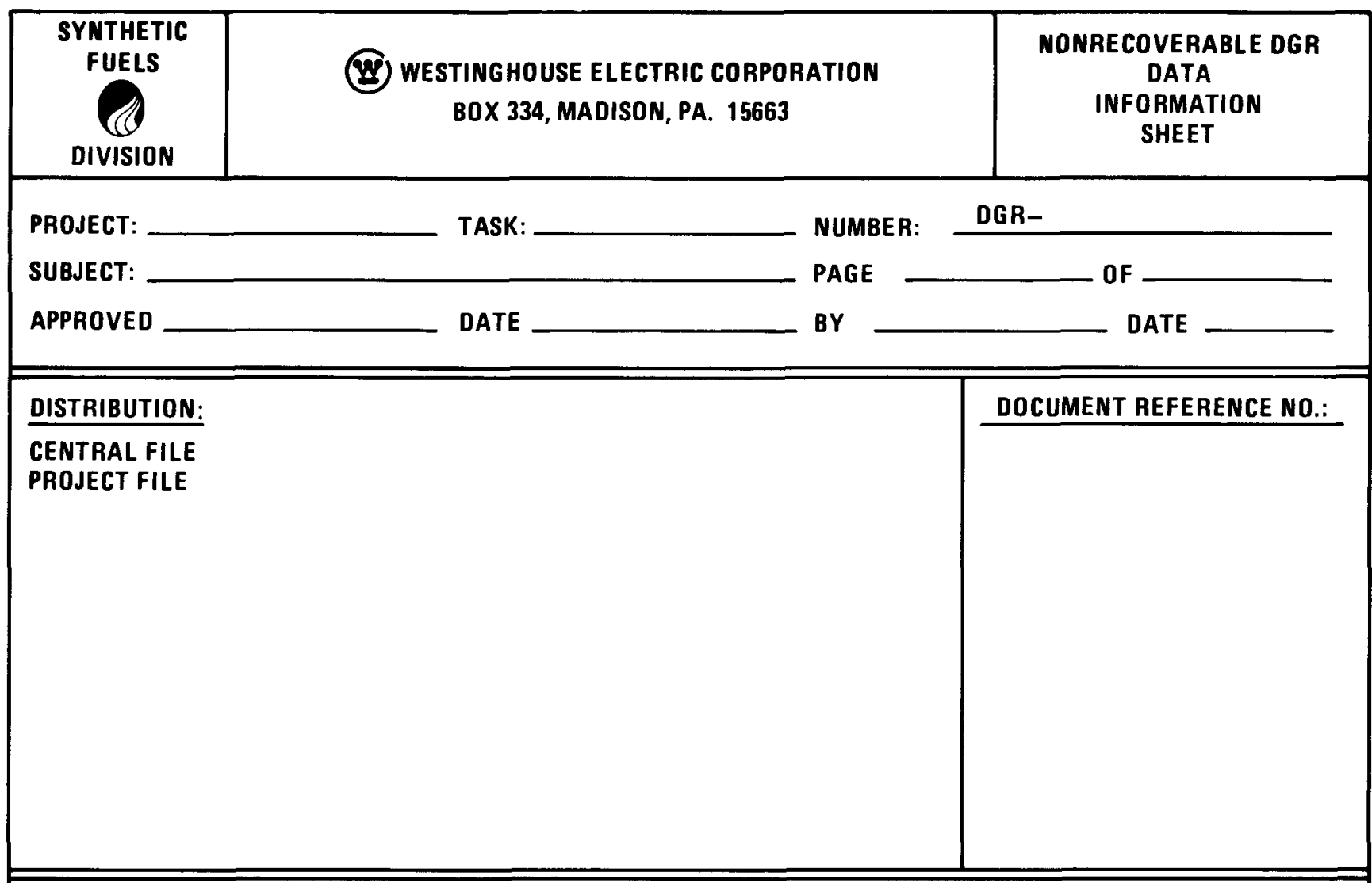

1.0 SUMMARY (PURPOSE / CONCLUSIONS / RECOMMENDATIONS)

2.0 TECHNICAL DISCUSSION (ASSUMPTIONS / METHODS / RESULTS)

3.0 DATA ATTACHMENTS (TABLES / GRAPHS / DRAWINGS)

Figure 1.4-2 Example of Data Information Cover Sheet (DIS) 


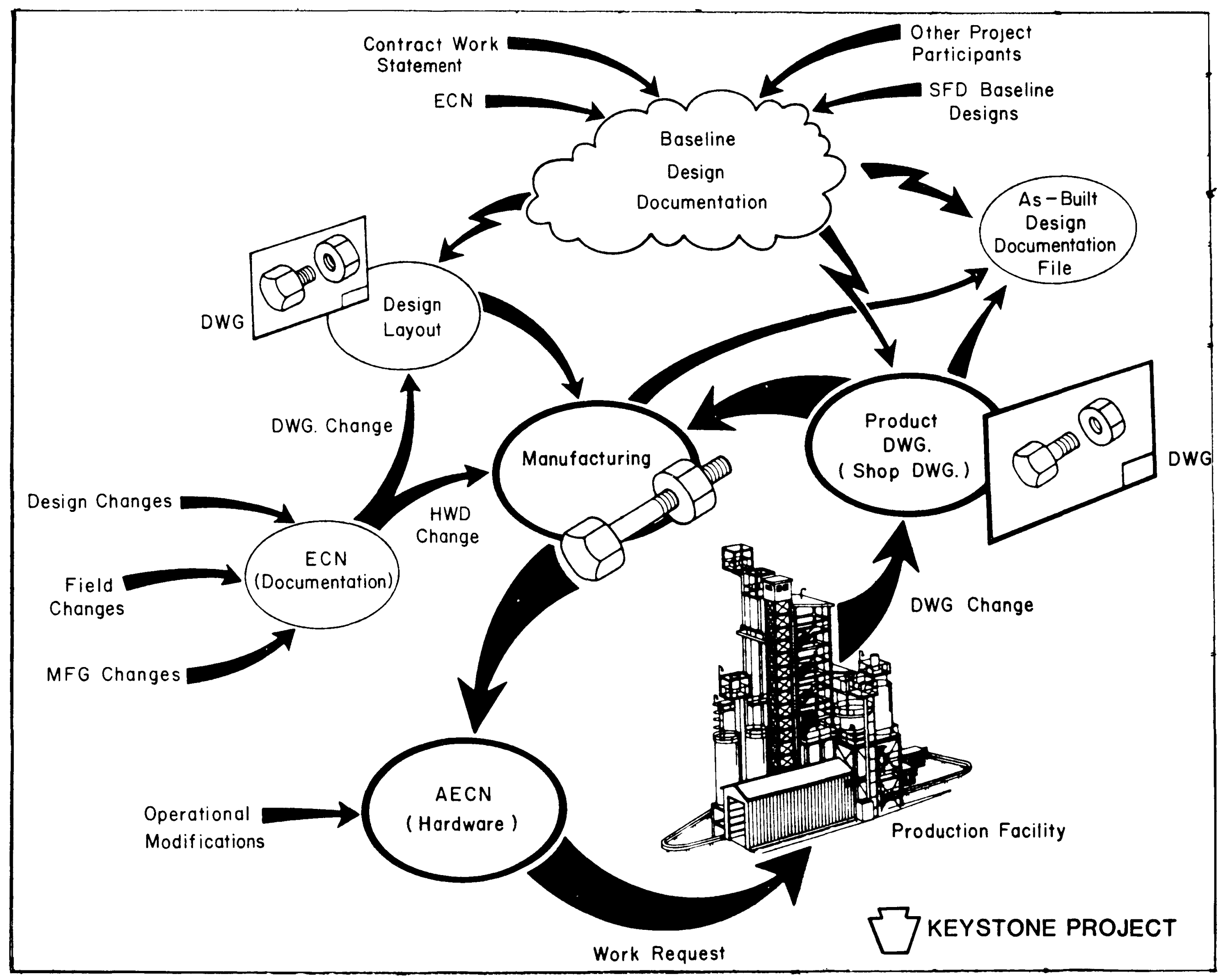

Figure 1.4-3 Project Configuration Control System 
cost. This information will be presented to established meetings of the Configuration Management/Change Control Board. After review of the change, the Board will either authorize or reject the change. If approved, the affected design documents, hardware or software schedules and budgets will be modified to reflect the change, and a new technical baseline will be established.

The design documents discussed in Section 1.4 .4 (excluding the DIS) are subject to change control. The responsibility for technical control and performance lies with the Project Manager (Engineering Manager during Operations).

\subsubsection{PROCUREMENT CONTROL}

All Keystone Project participants will be bound by contracts that define responsibilities, scope of work, terms and conditions, relationship to other participants, schedules for accomplishing contractual tasks, financial

provisions, mechanisms for insuring compliance with project technical and financial requirements and procedures for accomplishing modifications to contractual provisions when required.

All changes that may affect technical, cost, schedule, quality or safety aspects of the project will be controlled by the configuration Management/Change Control Board. These changes will be subject to uniform controls within the participant organization and/or the Project Management Office, depending on the limit of authority. All claims of significant changes in the amount or character of contracted work must be documented by the contractor and authorized by the Project Configuration/Change Control Board prior to the initiation of work.

Each project participant will schedule procurement actions required to complete contracted tasks on the Level II schedules. These activities are established to support activities and milestone data on the Level I schedule and include technical reviews and approvals (that is, design reviews and baseline approval as required) and vendor evaluations. These controls are established by individual contractors using internal purchasing systems and 
procedures for procurement with in the contractor's limits of authority and within project management's authority for those requiring project office approval.

\subsection{RISK MANAGEMENT PROGRAM}

The Keystone Project will maintain a highly visible program to identify, evaluate and mitigate any risks that could lead to adverse consequences on the project's technical and economic performance. This section describes the risk management program that has been established for the project.

\subsubsection{RESPONS IB IL ITIES AND OBJECTIVES}

The Senior Advisory Board, assisted by the General Counsel, will have primary responsibility for implementing and operating the project's risk management program. The composition and general activities of this Board have been described briefly in Section 1.2. The three, senior-level, experienced people on the Board report to the General Manager of Keystone Associates. The Board will mainly serve as a strategic planning and fact-finding body that works with the line staff to obtain information on and evaluate subjects of interest to the project. The Board will hold periodic formal reviews of specified risk areas. Its members will be ex-officio members of all project committees, and will, therefore, have wide access to available information.

There are three objectives of the risk management program:

(1) To monitor and evaluate areas of potential business risk to the project;

(2) To provide early warning and analys is of both internal and external trends that can materially affect the project's technical and financial status; and

(3) To suggest corrective or mitigating actions that can reduce the effect of identified risks on the project. 


\subsubsection{RISK IDENTIFICATION AREAS}

The project's risk management program is broad-scoped and will function in the following general areas:

- Technical

- design

- fabrication

- construction

- operation

- maintenance

- Financial

- costs

- schedule

- financing

- product marketing

- external economic outlook

- Regulatory

- environmental

- permitting

- health and safety

- Legal/Political

- legislation

- governmental affairs

- community relations

\subsubsection{RISK MANAGEMENT ACTIVITIES}

The Keystone Project considers management of risks to be important in enabling the financial community to evaluate the suitability of the project as a sound investment opportunity. The principal risks of the project arise from the following major categories: Design/construction, operating costs, product marketing, financial costs and political/legislative. 
Keystone Project management practices will mitigate many risks during the design/construction period. These practices will be the primary responsibility of project management but will also be part of the Senior Advisory Board's risk management activities. The practices will be part of ongoing control efforts and will include the following:
- Periodic design reviews
- Periodic budget/schedule reviews
- Variance analyses
- Corrective action plans
- Safety analysis and reviews
- Plant hazards analys is
- Failure mode and effects analysis.

The objective of the above activities will be to assure that the project is designed and constructed according to the specifications established within the prescribed budget and schedule.

A major risk mitigation activity is the compatibility of the Keystone schedule with that for design and construction of a similarly-sized, commercial-scale Westinghouse gasifier at the SASOL II complex in the Republic of South Africa. Although design requirements for gasifiers at the two facilities are different, experience gained on the SASOL project will have some relevance for Keystone. The SASOL project is currently in the detailed design phase. Construction is scheduled to begin in October 1983, and operation will begin in December 1984. These dates predate comparable milestones for Keystone by a significant margin, as illustrated in Figure 1.5-1. Consequently, when the SASOL unit goes on-line, some essential features of the Keystone gasifier design will be tested on a $1: 1$ scale with a unit operating at a commercial facility. Critical information learned during the first months of SASOL operation in early 1985 could still be factored into the procurement activities for the Keystone gasifier. At the very least, experience gained from final design, procurement and construction at SASOL will be relevant to Keystone. Thus, the SASOL demonstration will substantially reduce the risk 
SASOL/KEYSTONE COMPARISON SCHEDULE

\begin{tabular}{|l|}
\hline DESCRIPTION \\
\hline ENGINEERING \\
\hline COST ESTIMATES \\
\hline PERMITS/LICENSES \\
\hline OFF-SITES \\
\hline SITE SERVICEIDEVELOPMENT \\
\hline GASIFICATION \\
\hline GAS CONDITIONING \\
\hline METHANOL SYNTHESIS \\
\hline BALANCE OF PLANT \\
\hline PROJECT INTEGRATION \\
\hline \\
\hline PROCUREMENT \\
\hline OFF-SITES \\
\hline SITE SERVIIEIDEVELOPMENT \\
\hline GASIFICATION \\
\hline GAS CONDITIONING \\
\hline METHANOL SYNTHESIS \\
\hline BALANCE OF PLANT \\
\hline \\
\hline CONSTRUCTION \\
\hline OFF-SITES \\
\hline SITE SERVICE/DEVELOPMENT \\
\hline EXCAVATION/CIVIL \\
\hline CONCRETE \\
\hline STRUCTURAL STEEL \\
\hline GASIFICATION \\
\hline GAS CONDITIONING \\
\hline METHANOL SYNTHESIS \\
\hline BALANCE OF PLANT \\
\hline PRECOMMISSION \\
\hline \\
\hline OPERATION \\
\hline TRAIIING \\
\hline UTLITY START-UP \\
\hline GASIFIER START-UP \\
\hline SYNTHESIS START-UP \\
\hline INITAL PRODUCTION \\
\hline \\
\hline \\
\hline \\
\hline
\end{tabular}

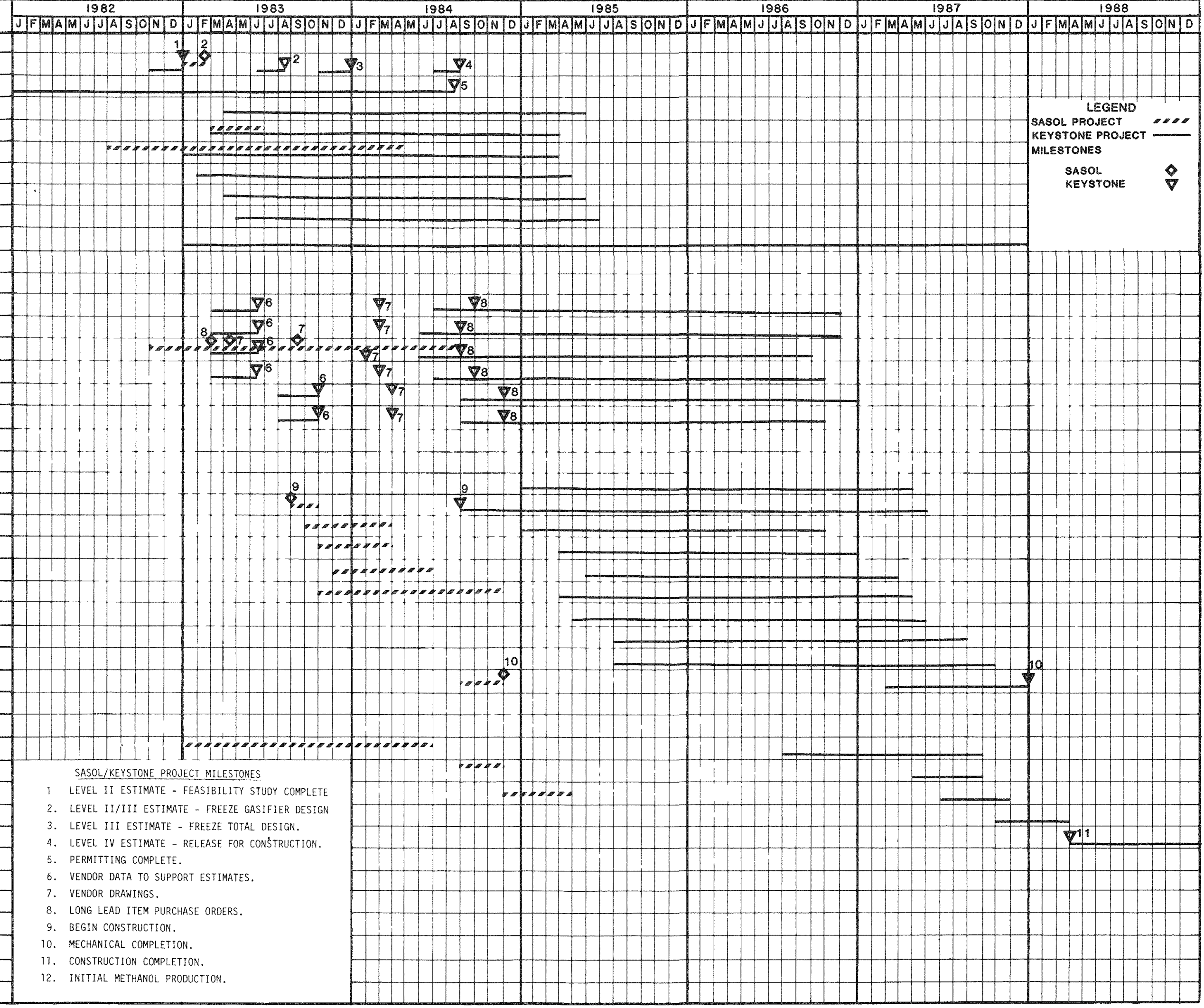

Figure 1.5-1 SASOL/KEYSTONE Comparison Scheduie 
and technical uncertainty of the Keystone Project, and it will complement the technology development programs continuing at the westinghouse Synthetic Fuels Division.

Table 1.5-1 groups a number of major potential risks to the project by category of risk and indicates both the nature of the resulting impact or exposure and the mitigation strategy that is being pursued by the project to control the risk. 
TABLE 1.5-1

KEYSTONE PROJECT RISKS AND MITIGATION STRATEGIES

Description of Risk

Impact/Exposure

Mitigation Strategy

1.0 Design/Construction

1.1 Construction cost exceeds estimate on a real cost bas is
- Additional equity and financing will be required (SFC bears lower percentage of any overrun )

- Greater debt service and higher product cost will result

- Return on invested capital will decrease
- Focus project cost estimate efforts prior to SFC award on areas of highest uncertainty

- Maximize use of commercially sized and proven systems

- Maintain sufficient contingency to cover uncertainties

- Take advantage of detailed cost information developed for SASOL Project

- Seek support for front-end engineering leading to refined cost estimates

- Implement strong project control system

- Negotiate a price support formula that increases with price inflation 
TABLE 1.5- 1

(cont inued)

\section{Description of Risk}

1.3 Plant fails to meet the projected operating capacities and achieve reliable continuous operation at high stream factors

\section{Impact/Exposure}

- Throughput and revenues will decrease

- Product cost will increase on a unit bas is
Mitigation Strategy

- Maximize use of proven processes and systems in plant

- Maximize transfer of technology and experience from other Westinghouse work on gasifier design and performance

- Test performance of typical Keystone coal in Process Development Unit (PDU) gasifier at SASOL
1.4 Delay in the construction schedule due to re-design, licensing delays, procurement problems or labor shortages
- Possible postponement of in-service date for realizing depreciation expense

- Costs subject to further escalation
- Perform critical designs as early as possible when sufficient information is available

- Obtain all permits needed for plant construction as soon as possible

- Incorporate contingencies in procurement schedule

- Negotiate project labor agreement
1.5 Plant experiences a prolonged startup period
- Interest and startup expenses will accrue without benefit of income

- Return on investment will be adversely affected processes and systems in
- Maximize use of proven the plant

- Maximize value of experience gained from SASOL demonstration

- Additional expenses may be required for re-design or plant fixes 
TABLE $1.5-1$

(continued)

Description of Risk

Impact/Exposure

Mitigation Strategy

2.0 Operating Costs

2.1 Plant experiences interruption of operation due to coal strike or major failure
- Revenues decrease

- Negotiate contracts with more than one supplier

- Maintain coal stockpile

- Design equipment with redundancy and ability to operate at partial load
2.2 Operating costs prove to be higher than expected, particularly coal
- Product cost will increase

- Negotiate long-term takeor-pay contract for coal requirements

- Negotiate price support formula that desensitizes coal escalation 
TABLE $1.5-1$

(continued)

Description of Risk Impact/Exposure Mitigation Strategy

3.0 Product Marketing

3.1 Size of the market willing to purchase plant's product is too small
- Inability to sell plant's output

- Plant forced to operate at sub-optimal capacity

- Plant will operate at a loss, which adversely affects project economics
- Attract organizational investor to project who has more direct access to market and can take steps to stimulate demand (i.e., a major oil company)

- Seek long-term contractual commitments for plant's output

- Continue programs to develop the market for methano 1
3.2 Price of plant's product falls or fails to rise sufficiently in real terms (i.e., $v$ is $-a-v$ is competitive fuels)
- Overall project economics will be adversely impacted

- Available price guarantee authority will be insufficient to meet debt service and cover operating costs
- Negotiate price guarantee formula with SFC that considers this eventuality 
TABLE 1.5- 1

(cont inued)

Description of Risk

Impact/Exposure

Mitigation Strategy

4.0 Financial

4.1 Financing costs are higher than expected
- Higher than expected interest cost reduces return on investment and increases product $\cos t$
- Negotiate price guarantee that hedges against higher interest
- Negotiate contingency in price guarantee authority than anticipated

- Price guarantee authority is insufficient
- Structure project price guarantees and loan guarantees to guarantee reasonable financial results during early operating period 
TABLE $1.5-1$

(cont inued)

Description of Risk Impact/Exposure Mitigation Strategy

5.0 Political/Legislative

5.1 Tax laws (federal or state) could change, resulting in loss of tax benefits or increases in $\operatorname{tax}$ rates
- Will affect overall return on investment and financial feasibility of project

- Effect of any 1 aw change could be either positive or negative, and it could be particularly severe
- Maintain close contact and observation of political scene

- Work with legislators to develop positive incentives to synthetic fuels projects

\subsection{Regulatory changes affecting plant and marketability of product could be passed \\ - environmental \\ - methanol use}

- Increase cost of plant construction and operation

- Decrease acceptance of methanol as a fue 1
- Monitor regulatory changes proposed that could affect synthetic fuels industry

\subsection{Public opposition develops against the project \\ - Permits are denied or delayed}

- Maintain strong interface with regulatory agencies

- Maintain good relations with neighbor ing community, including public information programs 
SECTION 2.0

ECONOMIC AND FINANCIAL ANAL YSES

The financial analyses performed for the Keystone Project are discussed in this section. The objective of the analyses was to establish the terms under which the project could be a sound business investment for equity partners given the potential availability of financial support from the United States Synthetic Fuels Corporation (SFC). Pro-forma financial statements for the project have been calculated for a base case using a consistent set of economic assumptions and the current capital cost estimate of the plant. Sensitivity analyses were completed to provide information on the effect of uncertainty and variability on project economics. Both an optimistic and pessimistic case have been investigated.

A brief discussion of the types of government-sponsored financial assistance available to the project from the SFC is also presented in this section, along with several options for organizing and qualifying for this support. The proposed financing plan developed for construction and operation of the project is summarized.

\subsection{ASSUMPT IONS FOR FINANCIAL ANAL YSES}

To carry out the financial analyses of the Keystone Project, the following general assumptions were made about the economy during the project's life:

(1) Moderate economic growth

(2) Gradually declining inflation

(3) Real interest rates remaining high by historical standards

(4) No major prolonged oil supply disruptions

Table 2-1 presents the values selected for key financial variables to reflect these assumptions about the future economy. Detailed assumptions for all other parameters required for the analyses, dealing with plant performance, schedule, capital and operating cost estimates are contained in Appendix $C$. 
$\underline{\text { Variable }}$

Capital cost (January 1982 dollars)

Builders all-risk insurance

Capital cost escalation

Interest on construction loan

Interest on long-term loan

Coal (1982 dollars)

Coal escalation

Ul timate plant capacity factor

Labor cost escalation

Electricity escalation
Base Case Value

$\$ 544$ million

$\$ 3$ million

9.0\% per year

$12 \%$

$12 \%$

$\$ 27$ per ton

1982-1990: 9.0\% per year

1990-2000: $7.0 \%$ per year

$82 \%$

1982-1990: $7.0 \%$ per year

1990-2010: $6.5 \%$ per year

1982-1990: $8.0 \%$ per year

1990-2010: $7.5 \%$ per year 


\subsection{SUMMARY OF RESULTS}

The financial analyses integrated the economic and technical data developed by the Feasibility Study with assumptions on price forecasts and tax considerations to obtain a forecast of project economic performance. From this forecast, various financial arrangements could be superimposed to evaluate their viability.

For example, project funding exclusively by sponsor equity was shown to require a guaranteed price for methanol of $\$ 3.35$ per gallon during the first ten years of plant operation in order to achieve a 30 percent discounted cash flow rate of return (DCFROR). This methanol price greatly exceeds both the existing price and the forecast price for a time period well beyond the project's startup date. Therefore, all-equity financing was not deemed feasible. Alternatively, leverage with SFC-guaranteed debt equal to 75 percent of project pre-production costs and assuming a lower methanol market price with no price supports, provided a DCFROR below 6 percent, which is not acceptable. Consequently, a combination of both loan guarantees and price supports is required to achieve financial viability for this project.

As summarized below and explained in detail later, there are several ways to structure the necessary financial assistance for the project. With a loan guarantee equal to 75 percent of project pre-production costs and a price support that escalates at the general rate of inflation through the first ten years of operation before terminating, the required January 1982 methanol support price is $88 k$ per gallon, based upon the best estimate assumptions. However, in the judgment of current project sponsors, a price support escalation tied only to general inflation fails to provide sufficient risk mitigation because factors besides inflation also affect the price of methanol.

Additional risk mitigation can be obtained by calculating price supports with a formula based on indices measuring cost escalation for construction, coal, 1 abor and interest. Such a formula, which is described more fully later, was developed to include these parameters and was used in the base case analyses. 
The base case results from this study using the support formula require a January 1982 methanol price of $\$ 1.07$ per gallon. This base price is escalated through 1997 according to the formula. The base case DCFROR to investors on their net equity capital is projected under the set of assumptions used to be 30 percent through the price support period (i.e., 1997) and 31 percent through the year 2010. Together with SFC loan guarantees equal to 75 percent of project pre-production costs, the corresponding maximum SFC exposure at the end of any year was calculated to be $\$ 830$ million when the methanol price forecast of PACE Engineers is assumed to represent the actual market price.

\subsection{F INANCIAL MODEL}

A computer model was developed to conduct the financial analyses. The model integrates the factors that contribute to cash and financial statement projections, including assumptions regarding $\mathrm{plant}$ performance, revenue, cost, tax and financing matters (see Appendix $C$ ). The approach used by the model is to determine the reference methanol price under the price support formula, which gives the desired rate of return for the project (i.e., a minimum DCFROR of 30 percent). This rate of return was selected as necessary to attract investor interest in the project, given the magnitude of risk and uncertainty involved. The model assumes that all tax benefits are utilized by project sponsors when they become available. The following pro-forma financial statements are developed by the model:

- Sources and uses of funds

- Cash flow

- Tax income statement

- Income for the venture and the venturers collectively

- Balance sheet for the venture and for the venturers collectively

- Sample analysis of venturers' financial exposure

The resulting statements indicate the annual cash requirements that must be provided by equity investors early in the project, and subsequently, the cash surplus available for distribution. Also developed are the net present values of venturers' equity at discount rates of 15,25 and 35 percent, as well as the DCFROR for both the period in which the price supports are in place (ending in 1997) and for the full project 1 ife. 
The sections below discuss major individual elements of costs and revenues that have been used in the financial calculations.

\subsubsection{PRE-PRODUCT ION EXPENDITURES}

Major costs during the pre-production period are associated with engineering, scheduling, procurement, construction and other expenses customarily incurred in the installation of a major facility. These include inventory costs for items such as a one-month coal stockpile, as well as costs for project office personnel activities, including supervision of the construction tasks, performance of environmental permitting and compliance functions and obtaining product sales agreements. In the latter stages of the pre-production period, additional costs will be incurred for training operations personnel and for startup materials as plant equipment is tested.

These pre-production costs are summarized in Table 2-2 in both constant and current dollars. The costs reflect the current capital cost estimate of the plant, \$547.3 million in January 1982 dollars, which includes $\$ 3$ million for builder's all-risk insurance.

\subsubsection{Pre-Production Period Funding Requirements}

It was assumed for the analyses that 75 percent of project pre-production costs will be funded by debt guaranteed by the SFC. This percentage applies uniformly throughout the construction period. Since it is anticipated that negotiations with the SFC will be concluded during 1983, no debt funding is used in 1983. However, in the early months of 1984, the debt component will exceed 75 percent until this percentage is attained for combined expenditures for 1983 and 1984.

This debt generates interest obligations, which must be added to other pre-production costs to determine total project funding requirements. Table 2-3 shows the total estimated pre-production costs in current dollars, the extent of SFC-guaranteed debt and the funding requirement of the project sponsors.

$4071 E$ 
TABLE 2-2

PRE-PRODUCTION COSTS (EXCLUDING FINANCING)

(MILLIONS OF DOLLARS)

\begin{tabular}{|c|c|c|c|c|c|c|c|c|}
\hline \multirow[b]{2}{*}{ Year } & \multicolumn{4}{|c|}{$\begin{array}{r}\text { January } 1982 \text { Dollars } \\
\end{array}$} & \multicolumn{4}{|c|}{ Current Dollars } \\
\hline & Plant Capital & Inventory & Expenses & Total & Plant Capital & Inventory & Expenses & Total \\
\hline 1983 & $\$ 8.2$ & & $\$ 0.6$ & $\$ 8.8$ & $\$ 9.3$ & & $\$ 0.7$ & $\$ 10.0$ \\
\hline 1984 & 102.3 & & 12.6 & 114.9 & 126.7 & & 13.1 & 139.8 \\
\hline 1985 & 123.2 & & 5.5 & 128.7 & 166.7 & & 7.1 & 173.8 \\
\hline 1986 & 177.9 & & 7.0 & 184.9 & 262.3 & & 9.6 & 271.9 \\
\hline 1987 & 135.7 & & 12.5 & 148.2 & 217.9 & & 18.3 & 236.2 \\
\hline 1988 (3 mo) & & $\$ 3.7$ & 15.5 & 19.2 & & $\$ 6.3$ & 25.1 & 31.4 \\
\hline TOTAL & $\$ 547.3$ & $\$ 3.7$ & $\$ 53.7$ & $\$ 604.7$ & $\$ 782.9$ & $\$ 6.3$ & $\$ 73.9$ & $\$ 863.1$ \\
\hline
\end{tabular}

NOTE: Plant capital and expenses are segregated into components in Appendix $C$. 


\section{TABLE 2-3}

FINANCING REQUIREMENTS DURING PRE-PRODUCTION PERIOD

(MILLIONS OF CURRENT DOLLARS)

\begin{tabular}{|c|c|c|c|c|c|}
\hline Year & $\begin{array}{l}\text { Non-Financial } \\
\text { Costs }\end{array}$ & $\begin{array}{l}\text { Interest } \\
012 \% \text { per yr. } \\
\text { (2) }\end{array}$ & $\begin{array}{c}\text { Total } \\
\text { Pre-Production } \\
\text { Costs } \\
\end{array}$ & $\begin{array}{c}\text { SFC- } \\
\text { Guaranteed } \\
\text { Debt } \\
\end{array}$ & $\begin{array}{l}\text { Investor } \\
\text { Funding } \\
\text { Requirement } \\
\end{array}$ \\
\hline 1983 & $\$ 10.0$ & & 10.0 & & $\$ 10.0$ \\
\hline 1984 & 139.8 & $\$ 7.1$ & 146.9 & $\$ 117.7$ & 29.2 \\
\hline 1985 & 173.8 & 23.0 & 196.8 & 147.5 & 49.3 \\
\hline 1986 & 271.9 & 46.1 & 318.0 & 238.5 & 79.5 \\
\hline 1987 & 236.2 & 74.4 & 310.6 & 233.0 & 77.6 \\
\hline 1988 (3 mo) & 31.4 & 22.7 & 54.1 & 40.6 & 13.5 \\
\hline TOTAL & $\$ 863.1$ & $\$ 173.3$ & $\$ 1,036.4$ & $\$ 777.3$ & $\$ 259.1$ \\
\hline
\end{tabular}




\subsubsection{OPERATING PER IOD EXPENDITURES}

Costs incurred during the plant operating period are primarily attributable to the following items: coal, electricity, operating and maintenance supplies, personnel costs, catalysts and chemicals, natural gas and water. Estimated costs for each of these items in January 1982 dollars and their assumed escalation rates are presented in the general assumption summary in Appendix C. All of these costs were assumed to vary with production level except those for supplies and personnel.

There are also other costs during this period. While there is no property tax in Pennsylvania, a real estate tax is applicable to such items as buildings, land and certain site improvements. Insurance is also necessary against property damage and injury to personnel. The basis for computing these costs is contained in Appendix $C$.

Two costs during the operating period occur only once. The first cost is repayment to the Department of Energy of the $\$ 4.8$ million grant for this feasibility study together with 5 percent annual interest, which results in approximately 96.8 million being paid by the project in 1988. The second cost is a fee for refinancing the short-term pre-production period debt into long-term debt in 1989, which is estimated to be 1.5 percent of the amount refinanced when legal and other attendant costs are included.

There are also two other costs related to financing. These are (1) payments of equal semiannual instaliments of principal, assumed to take place over 20 years without a grace period, and (2) payments of accrued interest on the outstanding principal balance, which is expected to be due at the time of each principal payment. For convenience, it was assumed that the accrued interest includes a 0.5 percent loan guarantee fee from the SFC.

\subsubsection{REVENUES}

Annual methanol production is affected by numerous factors. These include (1) the heating value of the coal $(12,300$ Btu per pound assumed), (2) the efficiency of converting the heating values of coal, electricity and natural 
gas to methanol (56 percent), and (3) the expected plant capacity factor (steady state of 82 percent). Annual methanol output was assumed to increase to a level of 168 million gallons in 1991 and to continue at this production rate through the year 2010 , the last year of the analys is.

The sections below discuss expected revenues from the sale of plant methanol and by-products .

\subsubsection{Price Support Formula}

The expected price to be received for methanol production through 1997 has been derived from a formula developed to determine the support price that would be payable by the SFC in any one month. This formula is set forth below:

$$
\begin{aligned}
& P_{N}=P_{B}\left[.22 \frac{C_{N}}{C_{0}}+.08 \frac{L_{N}}{L_{0}}+.24 \frac{K_{C}}{K_{0}}+.46 \frac{I_{R}}{I_{0}}\right] \\
& \text { where } P_{N} \quad-- \text { is the Computed Reference Price in month } N, \$ \text { per } \\
& \text { gallon } \\
& P_{B} \quad-- \text { is the Computed Reference Price in Jan. 1982, \$ per } \\
& \text { gallon } \\
& \mathrm{C}_{\mathrm{N}} \quad-- \text { is the National Contract Coal Price Index in month } \\
& \text { (N), Wholesale Price Index } 05120301 \\
& C_{0} \quad-- \text { is the National Contract Coal Price Index as of } \\
& \text { January } 1982 \\
& L_{N} \quad \ldots \text { is the Value of the Bureau of Labor Statistics } \\
& \text { Chemical Process Labor Index Series AHE } 28 \text { in month (N) } \\
& \mathrm{L}_{0} \quad--- \text { is the Value of the Chemical Process Labor Index in } \\
& \text { January } 1982 \\
& \mathrm{~K}_{\mathrm{C}} \quad-- \text { is the Nelson Refinery Index at the Keystone project } \\
& \text { in-service date } \\
& \mathrm{K}_{0} \quad \text {--- is the Nelson Refinery Index in January } 1982
\end{aligned}
$$


$I_{R} \quad--$ is the yield to maturity of 10-year Treasury bonds or notes, as published in the Federal Reserve Bulletin, at the point of permanent refinancing (or the average of the yields if the project is refinanced in stages)

$\mathrm{I}_{0} \quad \ldots$ is the yield to maturity of 10-year Treasury bonds or notes in January 1982.

This formula will adjust escalation of the support price to changes in the escalation rate of costs for construction, coal and 1 abor, as reflected by the indicated indices, and to any interest rate change realized on the refinanced debt from that anticipated. After refinancing, the construction and interest components, constituting 70 percent of the weighting, become fixed, with only the remaining 30 percent available to cause further price changes. This structure for the formula was designed to hedge the risk of the project, since it would no longer be affected by construction cost escalation and interest rate fluctuations after the debt is refinanced to long-term instruments. Recognition of this reduced cost sensitivity by the project through the formula also results in lower SFC financial exposure to a rising support price.

Alternative price support arrangements that escalate a January 1982 base methanol price by a single index, such as the GNP deflator, are easily designed with or without an additional component for real escalation. While such approaches are less complex, they do not provide the risk mitigation of a formula tied to the major cost elements of the project. Moreover, they fail to reflect the difference in the cost exposure that exists before and after construction and refinancing are completed. For these reasons, other approaches were rejected in favor of the formula given.

The base case financial projections for the years 1998 and 1999 adopted extrapolated methanol prices from the forecast of PACE Engineers. The year 2000 price was the estimated PACE price, which was then escalated at the assumed rate of general inflation until 2010 . 


\subsubsection{Salable By-Products}

Salable by-products include food-grade carbon dioxide, sulfur and ammonia. Annual production, expected prices, revenue and assumed price escalation are included in the detailed assumptions given in Appendix $C$.

\subsubsection{Accounts Receivable}

Proceeds from all sales were assumed to be received one month after the sale, thereby resulting in a working capital requirement that must be financed by the project. This requirement was included in the analyses.

\subsection{TAX CONS IDERAT IONS}

Tax benefits represent a major factor in the economics and financing of the project. During the pre-production period, tax benefits are available to equity investors which offset some of the investment requirements, and this, in turn, reduces the net equity they must contribute. During the early years of the operating period, non-cash deductions, primarily from depreciation, constitute a major factor in providing cash flow for debt service and rapid payback of the equity investment.

\subsubsection{TAX TREATMENT DURING THE PRE-PRODUCTION PER IOD}

During the pre-production period, all costs directly attributable to the design and construction of the plant were capitalized except for sales tax, which was expensed as incurred. The 10 percent investment tax credit was taken on a qualified progress expenditure basis after 1983 on capitalized costs, except those for land, buildings and certain site improvements that do not qualify. Project office, training and startup costs were expensed.

Interest on the debt during the construction period could have been deducted as incurred prior to the passage of the Tax Equity and Fiscal Responsibility Act of 1982. This Act now precludes the current deduction of interest on debt used to finance "real property," a term that was left undefined. 
Given the uncertainty as to the definition of "real property" to be provided by the Treasury, the most conservative treatment was assumed, and all interest was capitalized under a Section 266 election. This permits the capitalized interest to quality for the investment tax credit on a pro-rata basis in proportion to the eligibility of project assets.

\subsubsection{TAX TREATMENT DUR ING THE OPERATING PER IOD}

Capitalized plant costs, excluding land, were depreciated under the Accelerated Cost Recovery System. The depreciable life is 5 years, except for costs attributable to buildings and site improvements that have a 15-year tax life. Interest during construction was deducted in cash flow projections at the same rate that depreciation was taken on other capital items.

\subsection{DETERMINATION OF THE F INANCING PLAN}

Base case economic assumptions used in the financial analyses are given in Appendix $C$.

Table 2-4 summarizes the results obtained for each of the cases studied in terms of the required loan guarantee, the initial guaranteed methanol price and the discounted cash flow rate of return (DCFROR). The loan guarantee is equal to 75 percent of the costs during construction and continues to apply to the loan after refinancing.

\subsubsection{ALL-EQUITY CASE}

An all-equity financing plan was studied, but it was found that the total assistance required to provide the minimum 30-percent return on equity believed necessary to attract project investors required an initial guaranteed price of $\$ 3.85$ per galion for methanol. In addition, the required total support exceeded the SFC's maximum assistance authority for a single project by more than a factor of two. Therefore, all-equity financing was not deemed viable. 
TABLE 2-4

SUMMARY OF FINANCIAL RESULTS

\begin{tabular}{cccc} 
& $\begin{array}{ccc}\text { Loan Guarantee } \\
\text { Thousands }\end{array}$ & Methanol Price & DCFROR on Equity \\
Case & Current $\$$ & \$Per Gallon (1982) & Through 1997 Overall \\
\hline
\end{tabular}

Base

777,264

$1.07 *$

30

31

A11-equity

0

$3.85^{\star}$

30

31

No-price support $777,264 \quad 80 \%$ of PACE forecast Negative 6

*Guaranteed price. 


\subsubsection{NO-PRICE SUPPORT CASE}

The no-price support case was run to determine if leverage alone would make the venture attractive to investors. An evaluation was made with SFC-guaranteed debt equal to 75 percent of project pre-production costs and a price equal to 80 percent of that forecasted by PACE Engineers. This price level was considered to provide adequate comfort to project investors without federal price supports. However, as indicated in Table 2-4, the rate of return was found to be only 6 percent overall, which is unacceptably low.

\subsubsection{BASE CASE}

The base case involves both a 75 percent loan guarantee and use of the price support formula discussed previously, combined with the set of best-estimate assumptions. In computing the level of price support necessary to make the project sufficiently attractive to investors, a base methanol price in January 1982 was derived for this case that provided a 30 percent DCFROR through 1997. This price, as shown on Table 2-4, was $\$ 1.07$ per gallon. For the life of the project (i.e., through 2010), use of this base support price yielded an overall DCFROR of 31 percent. The pro-forma financial statements for this base case are give as Table 2-5.

If the project alternatively used a price support formula that escalated only at the general rate of inflation, the January 1982 base support price for methanol would be lower. Using this alternative price guarantee approach, it was determined that a base price of $88 \notin$ per gallon would provide the required 30 percent DCFROR through 1997. However, this approach is not only deemed by the project to be less favorable than the more comprehensive price support formula adopted but also the simplified approach results in higher total price support payments by the SFC under the set of base case assumptions.

\subsubsection{COMPAR ISON BETWEEN METHANOL SUPPORT PRICE AND FORECASTED PRICES}

Figure 2-1 depicts the methanol price during the plant operating period to 1997 calculated by the price support formula, together with prices forecast by PACE Engineers and Data Resources, Inc. The support price falls below even 


\section{CASH FLOW}

EEYTONE PROJECT -TOTAL PROJECT BASIS- (THOUSANDS OF CURREN DOLLARS) BASE CASE

ASSUMES GOVERNMENT LOAN GUARANTEES EQUAL TO $75 \%$ OF PRE-PRODUCTION COSTS AND PRICE SUPPORT THROUGH 1997 FROM 51 O $7 / G A L$ IN $1 / 82$ CASH FLOW STATEMENT

1983

1985

1986

1987

1988
88895
1989

$\begin{array}{rrrr}1988 & 1989 & 1990 & 1991 \\ 88895 & 161442 & 165529 & 167573\end{array}$

157

167573
$1 \quad 67$

1992

$\begin{array}{rrr}1992 & 1993 & 1994 \\ 67573 & 167573 & 167573\end{array}$

METHANOL \$/GAL

REVENUE

METHANOL

BY-PRODUCTS

TOTAL REVENUE

$\begin{array}{lllllll}132860 & 252750 & 268342 & 279042 & 286939 & 295379 & 304401\end{array}$

9565

CASH OPERATING EXPENSE

COAL

OP SMAINT SUPPLIES

PERSONNEL COST

OTHER OPERATING 1 ,

TOT CASH OP EXP

CASH NON-OPERATING EXPENSE

INS SREAL EST TAX

MISC SREAL EST TAX

MISCELEANEOUS ( 2$)$

$673 \quad 13100$

$108 \quad 7055$

18430

20220

21698

22999

25842

COT

TAX DEPRECIATION

PRE-PROD INT DEDUC

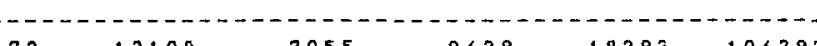

288561

300740

$309938 \quad 319758 \quad 330243$

TOTAL EXPENSES

67

TAX IBT

FED\&ST INCOME TA

TAX CREDIT

\section{SAOURCE AND USE OF FUNDS}

CASH FLOW (INITIAL "+" DENOTES SOURCE OF FUNDS. "-" INDICATES USE OF FUNDS)

+TAX DEPRECIATION +PRE-PROD INT DED

TRE PLANT S EOUIP

-PRE-PROD INTEREST

-PRE-PROD INTEREST

+NON-RECOURSE LOAN

$6602 \quad 13362 \quad 21983$

17732

108131191

16765

14253

38808

42037

44980

48

$9332 \quad 126730 \quad 166677 \quad 262254 \quad 217907$

5324

24570

15251

26290

37189

44980
39978

48129

51498

$\begin{array}{llll}16166 & 17136 & 18164 & 19254\end{array}$

$\begin{array}{llll}16999 & 29819 & 31757 & 33821\end{array}$

$69905115871 \quad 127421 \quad 1373271468910157124$

-PRINCIPAL REPAY

$405 \%$

NET CASH FLOW

$-9657$

$-9511-28760 \quad-47893 \quad-40129 \quad 5225$

CUMULATIVECASHFLOW $-9657-19168-47927-95820-135949-83695$

CUMULATIVECASHFLOW $-9657-19168-47927-95820-135949-83695$

(1) INCLUDES COSTS EOR WATER NATURAL GAS AND CATALYSTS \& CHEMICALS

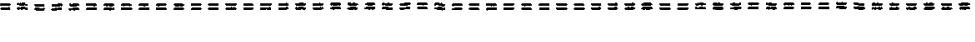

(2) INCLUDES COSTS FOR PRE-PRODUCTION PROJECT OFFICE. SALES TAX, TRAININ
NPVE $15 \%$ ISCOUNTING (OVERALL) 101694
(THROUGH 1997 )

NPVE 25\%DISCOUNTING "

NPVE $35 \%$ I SCOUNT ING

$-8441$

14497
-9746

$-9746$

$30 \%$

$O F 1988 \quad 133653$

$7743 \quad 8207 \quad 8700$

DCF RATE OF RETURN

$31 \%$ 


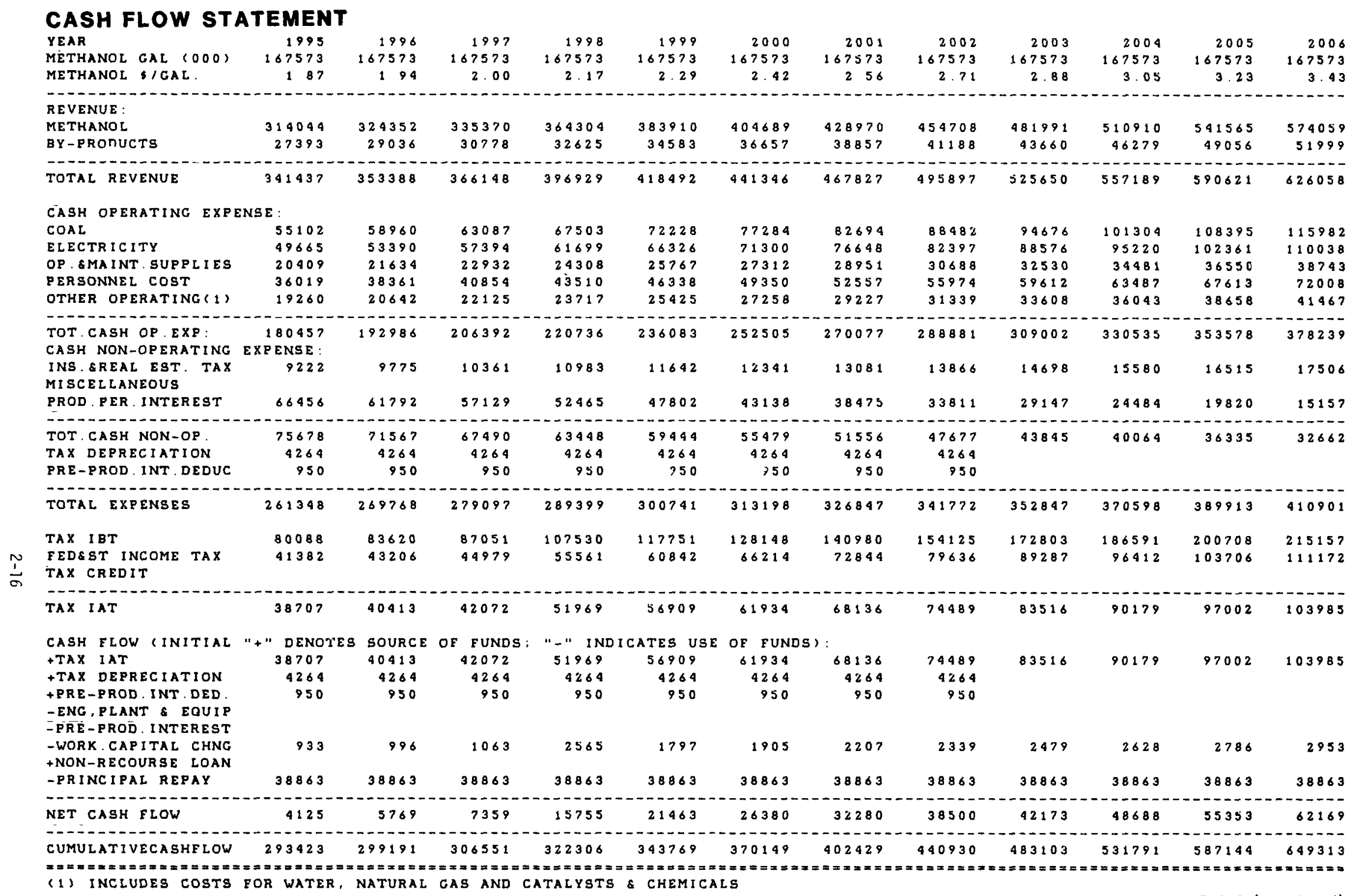




\section{CASH FLOW STATEMENT}

\begin{tabular}{|c|c|c|c|c|c|}
\hline YEAR & 2007 & 2008 & 2009 & 2010 & TOTAL \\
\hline METHANOL GAL $(000)$ & 167573 & 167573 & 167573 & 167573 & 3767327 \\
\hline METHANOL \$/GAL & $\begin{array}{ll}3 & 63\end{array}$ & 385 & 408 & 432 & \\
\hline EVENUE & & & & & \\
\hline REVENUE & & & & & \\
\hline METHANOL & 608502 & 645012 & 683713 & 724736 & 9600545 \\
\hline BY-PRODUCTS & 55119 & 58426 & 61932 & 65648 & 846371 \\
\hline 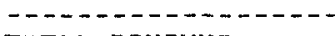 & & & & $\cdots--\cdots$ & $\cdots \cdots$ \\
\hline TOTAL REVENUE & 663622 & 703439 & 745645 & 790364 & 10496916 \\
\hline CASH OPERATINC EXPE & NSE & & & & \\
\hline $\mathrm{COAL}$ & 124101 & 132788 & 142084 & 152029 & 1814608 \\
\hline ELECTRICITY & 118291 & 127163 & 136700 & 146953 & 1695191 \\
\hline OP SMAINT SUPPLIES & 41068 & 43532 & 46144 & 48913 & 635013 \\
\hline PERSONNEL COST & 76689 & 81679 & 86982 & 92636 & 1154685 \\
\hline OTHER OPERATING( 1 ) & 44483 & 47722 & 51200 & 54937 & 639397 \\
\hline 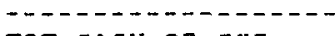 & & & & & 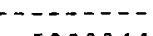 \\
\hline TOT CASH OP EXP & 404632 & 432878 & 463110 & 495468 & 5938844 \\
\hline CASH NON-OPERATINC & EXPENSE & & & & \\
\hline INS SREAL EST TAX & 18556 & 19669 & 20849 & 22100 & 286550 \\
\hline MISCELLANEOUS & & & & & 92233 \\
\hline PROD PER INTEREST & 10493 & 5829 & 1166 & & 1072624 \\
\hline 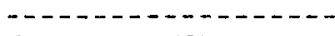 & $\cdots--1$ & & $\cdots--$ & & $\cdots-\cdots$ \\
\hline TOT CASH NON-OP & 29049 & 25499 & 22015 & 22100 & 1451407 \\
\hline TAX DEPRECIATION & & & & & 744115 \\
\hline PRE-PROD INT DEDUC & & & & & 165847 \\
\hline 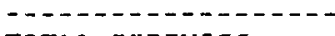 & & & & $-\cdots---$ & \\
\hline TOTAL EXPENSES & 433680 & 458377 & 485126 & 517569 & 8300212 \\
\hline TAX IBT & 229941 & 245062 & 260520 & 272815 & 2146704 \\
\hline FEDEST INCOME TAX & 118811 & 126623 & 134610 & 140964 & 1109202 \\
\hline TAX CREDIT & & & & & 87291 \\
\hline 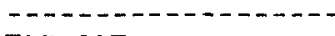 & & & & & \\
\hline ГAX IAT & 112131 & 118438 & 125909 & 131852 & 1129793 \\
\hline
\end{tabular}

CASH FLOW (INITIAL "+" DENOTES SOURCE, "-" USE OF EUNDS)

+TAX IAT $111131118438 \quad 125909 \quad 1318521124793$

+TAX DEPRECIATION $\quad 794115$

$\begin{array}{ll}\text { +PRE-PROD INT DED } & 165847\end{array}$

$\begin{array}{ll}\text {-ENC, PLANT \& EQUIP } & 782900 \\ - \text { PRE-PROD INTEREST } & 173303\end{array}$

$\begin{array}{lllllr}\text {-PRE-PROD INTEREST } & & & & & \\ \text {-WORK CAPITAL CHNG } & 3130 & 3318 & 3517 & -68464 & 17303\end{array}$

+NON-RECOURSE LOAN

-PRINCIPAL REPAY $38863 \quad 38863 \quad 38863 \quad 777264$

NET CASH FLOW 69137 76257 83529 200316 1078552

CUMULATIVECASHFLOW $718450 \quad 79470 ? \quad 8782361078552$

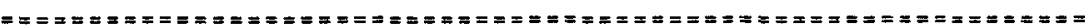

(i) INCLUDES COSTS FOR WATER, NAT GAS AND CATALYSTS\&CHEMICALS 
XEYSTONE PROJECT -TOTAL PROJECT BASIS- (THOUSANDS OF CURRENT DOLLARS) BASE CASE

ASSUMES GOVERNMENT LE X GUARANTEES EQUAL TO $75 \%$ OF PRE-PRODUCTION COSTS AND PRICE SUPPORT THROUGH 1997 EROM 51 O $7 / G A L$ IN $1 / 82$ TAX INCOM STATEMTII!

METHANOL GAL $(000)$

$1983 \quad 1984 \quad 1985$

$1986 \quad 1987$

$\begin{array}{rrrrrrr}1988 & 1989 & 1990 & 1991 & 1992 & 1993 & 1994 \\ 88895 & 161442 & 165529 & 167573 & 167573 & 167573 & 167573\end{array}$

METHANOL S/GAL

REVENUE

METHANOL

149

15

162

67573

1675

67573

182

BY-PRODUCTS

132860

TOTAL REVENUE

9565

142425

271181

268342

$(-0 .-$

171

176

-

EXPENSES

COAL

OP SMAINT SUPPLIES

PERSONNEL COST

OTHER OPERATING (1)

TOT CASH OP EXP

CASH NON-OPERATINC EXPENSE

CASH NON-OPERATING EXPENSE

INS SREAL EST TAX

PROD PER INTEREST

TOT CASH NON-OP

TAX DEPRECIATION
FRE-PROD INT DEDUC

17732

288561

$\begin{array}{rrrr}279042 & 286939 & 295379 & 304401 \\ 21698 & 22999 & 24379 & 25842\end{array}$

300740309938319758330293

TOTAL EXPENSES

INCOME BEFORE TAX

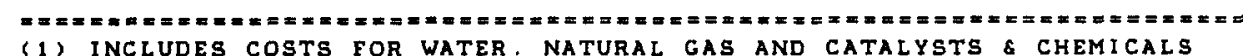

(1) INCLUDES COSTS POR WATER. NATURAL GAS AND CATALYSTS G CHEMICALS

$\begin{array}{lllllll}17732 & 34725 & 38808 & 42037 & 44980 & 48129 & 51498\end{array}$

19261

10824

$16765 \quad 24570$

$5324 \quad 11181$

$69905 \quad 115871$

34274

15251

$37189 \quad 39978$

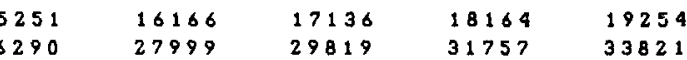




\section{TAX INCOME STATEMENT}

\begin{tabular}{|c|c|c|c|c|c|c|c|c|c|c|c|c|}
\hline EA & 1995 & 1996 & 1997 & 1998 & 1999 & 2000 & 2001 & 2002 & 2003 & 2004 & 2005 & 2006 \\
\hline METHANOL GAL $(000)$ & 167573 & 167573 & 167573 & 167573 & 167573 & 167573 & 167573 & 167573 & 167573 & 167573 & 167573 & 167573 \\
\hline METHANOL /GAL & 187 & 194 & 200 & $2 \quad 17$ & $2 \quad 29$ & $\begin{array}{ll}2 & 42\end{array}$ & 256 & 271 & 288 & 305 & 323 & 343 \\
\hline \multicolumn{13}{|l|}{ REVENUE } \\
\hline METHANOL & 314044 & 324352 & 335370 & 364304 & 383910 & 404689 & 428970 & 454708 & 481991 & 510910 & 541565 & 574059 \\
\hline BY-PRODUCTS & 27393 & 29036 & 30778 & 32625 & 34583 & 36657 & 38857 & 41188 & 43660 & 46279 & 99056 & 51999 \\
\hline 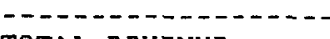 & & 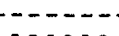 & & $-\cdots-\cdots$ & & & ---1 & 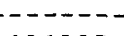 & & -2 & $-\infty-\infty$ & 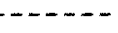 \\
\hline TOTAL REVENUE & 341437 & 353388 & 366148 & 396929 & 418492 & 441346 & 467827 & 495897 & 525650 & 557189 & 590621 & 626058 \\
\hline \multicolumn{13}{|l|}{ EXPENSES } \\
\hline $\operatorname{COAL}$ & 55102 & 58960 & 63087 & 67503 & 72228 & 72284 & 82694 & 88482 & 94676 & 101304 & 108395 & 115982 \\
\hline ELECTR ICITY & 49665 & 53390 & 57399 & 61699 & 66326 & 71300 & 76648 & 82397 & 88576 & 95220 & 102361 & 110038 \\
\hline OP SMAINT SUPPLIES & 20409 & 21634 & 22932 & 24308 & 25767 & 27312 & 28951 & 30688 & 32530 & 34881 & 36550 & 38743 \\
\hline PERSONNEL COST & 36019 & 38361 & 40854 & 43510 & 46338 & 49350 & 52557 & 55974 & 59612 & 63487 & 67613 & 72008 \\
\hline OTHER OPERATINC(1) & 19260 & 20642 & 22125 & 23717 & 25425 & 27258 & 29227 & 31339 & 33608 & 36043 & 38658 & 41467 \\
\hline $\begin{array}{l}\text { TOT CASH OP EXP } \\
\text { CASH NON-OPERATING }\end{array}$ & $\begin{array}{l}180457 \\
\text { EXPENSE }\end{array}$ & 192986 & 206392 & 220736 & 236083 & 252505 & 270077 & 288881 & 309002 & 330535 & 353578 & 378239 \\
\hline $\begin{array}{l}\text { INS EREAL EST TAX } \\
\text { MISCELLANEOUS }\end{array}$ & 9222 & 9775 & 10361 & 10983 & 11642 & 12341 & 13081 & 13866 & 14698 & 15580 & 16515 & 17506 \\
\hline PROD PER INTEREST & 66456 & 61792 & 57129 & $\$ 2465$ & 47802 & 43138 & 38475 & 33811 & 29147 & 24484 & 19820 & 15157 \\
\hline TOT CASH NON-OP & 75678 & 71567 & 67490 & 63448 & 59444 & 53479 & 51556 & 47677 & 43845 & 40064 & 36335 & 32662 \\
\hline TAX DEPRECIATION & 4264 & 9264 & 4264 & 4264 & 4264 & 4264 & 4264 & 9264 & & & & \\
\hline PRE-PROD INT DEDUC & 850 & 950 & 950 & 950 & 950 & 950 & 950 & 950 & & & & \\
\hline TOTAL EXPENSES & 261348 & 269768 & 279097 & 289399 & 300741 & 313198 & 326847 & 341772 & 352847 & 370598 & 389913 & 410901 \\
\hline NCOME BEEORE TAX & 80088 & 83620 & 87051 & 107530 & 117751 & 128148 & 140980 & 154125 & 172803 & 280591 & 200708 & 215157 \\
\hline
\end{tabular}

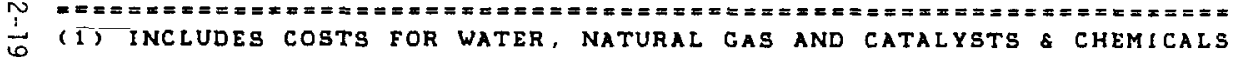




\begin{tabular}{|c|c|c|c|c|c|}
\hline \multicolumn{6}{|c|}{ TAX INCONESTATEMENT } \\
\hline METHANOL GAL (OOU) & 167573 & 167573 & 167573 & 167573 & 3767327 \\
\hline METHANOL /GAL & 363 & 385 & 408 & 432 & \\
\hline \multicolumn{6}{|l|}{ REVENUE } \\
\hline METHANOL & 608502 & 645012 & 683713 & 724736 & 9600545 \\
\hline BY-PRODUCTS & 55119 & 58426 & 61932 & 65648 & 846371 \\
\hline$m-n-m-n$ & $--\ldots$ & $\ldots-$. & 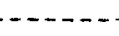 & 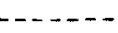 & $---\infty-n$ \\
\hline TOTAL REVENUE & 663622 & 703439 & 745645 & 790384 & 10946916 \\
\hline \multicolumn{6}{|l|}{ EXPENSES } \\
\hline COAL & 124101 & 132788 & 142084 & 152029 & 1814608 \\
\hline ELECTRICITY & 118291 & 127163 & 136700 & 146953 & 1695141 \\
\hline OP \&MAINT SUPPLIES & 41068 & 43532 & 46144 & 48913 & 635013 \\
\hline PERSONNEL COST & 76689 & 81674 & 86982 & & 1154685 \\
\hline OTHER OPERATINE ( 1 ) & 44483 & 47722 & 51200 & 54937 & 639397 \\
\hline TOT CASH OP EXP & 404632 & 432878 & 463110 & 495468 & 5938844 \\
\hline CASH NON-OPERATING & EXPENSE & & & & \\
\hline INS \&REAL EST TAX & 18556 & 19669 & 20849 & 22100 & 286550 \\
\hline MISCELLANEOUS & & & & & 92233 \\
\hline PROD PER INTEREST & 10493 & 5829 & 1166 & & 1072624 \\
\hline 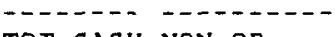 & & & & & \\
\hline TOT CASH NON-OP & 29049 & 25499 & 22015 & 22100 & 1951407 \\
\hline TAX DEPRECIATION & & & & & 794115 \\
\hline PRE-PROD INT DEDUC & & & & & 165847 \\
\hline TOTAE EXPENSES & 433680 & 458377 & 489126 & 517569 & 8300212 \\
\hline INCOME BEFORE TAX & 229941 & 245062 & 260520 & 272815 & 2146704 \\
\hline
\end{tabular}

$\sim$ (1) INCLUDES cosTs FOR WATER, NAT GAS AND CATALYSTS\&CHEMICALS 


\begin{tabular}{|c|c|c|c|c|c|c|c|c|c|c|c|c|}
\hline \multicolumn{13}{|c|}{ VENTURE STATIIENT OF INCOKAE (BOOK) } \\
\hline \multicolumn{13}{|l|}{ REVENUE } \\
\hline METHANOL & & & & & & 132860 & 252750 & 268342 & 279042 & 286939 & 295379 & 304401 \\
\hline BY-PRODUCTS & & & & & & 9565 & 18430 & 20220 & 21698 & 22999 & 2.4390 & 25842 \\
\hline TOTAL REVENUE & & & & & & 142425 & 271181 & 288561 & 300740 & 309938 & 319758 & 330243 \\
\hline \multicolumn{13}{|l|}{ EXPENSES } \\
\hline OPERATING & & & & & & 69905 & 115871 & 127421 & 137327 & 146891 & 157124 & 168745 \\
\hline DEPRECIATION & & & & & & 17340 & 34680 & 34680 & 34680 & 34680 & 34680 & 34680 \\
\hline INTEKES'1 & & & & & & 73805 & 100974 & 97476 & 92813 & 88149 & 83486 & 78822 \\
\hline OTHER EXPENSE( 1 ) & 673 & 13108 & 7055 & 9629 & 38292 & 36338 & 18099 & 6891 & 7304 & 7743 & 8207 & 8700 \\
\hline TOTAL EXPENSES & 673 & 13108 & 7055 & 9629 & 18292 & 97389 & 269629 & 266968 & 272124 & 277464 & 283497 & 290947 \\
\hline INCOME BEFORE TAX & -673 & -13108 & -7055 & -9629 & -18292 & -54964 & 1557 & 22093 & 28616 & 32474 & 36261 & 39296 \\
\hline
\end{tabular}

\begin{tabular}{|c|c|c|c|c|c|c|c|c|c|c|c|c|}
\hline YEAR & 1983 & 1989 & 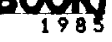 & 1986 & 1987 & 1988 & 1989 & 1990 & 1991 & 1992 & 1993 & 1994 \\
\hline INVESTMENT INCOME & -673 & -13108 & -7055 & -9629 & -18292 & -59964 & 1557 & 22093 & 28616 & 32474 & 36261 & 39296 \\
\hline INCOME TAX & -348 & -6773 & -3645 & -4975 & -9951 & -93139 & 804 & 11416 & 14786 & 16780 & 18736 & 20304 \\
\hline INCOME AFTER TAX & -325 & -6335 & -3410 & -4654 & -8841 & 38175 & 752 & 10678 & 13830 & 15695 & 17525 & 18992 \\
\hline EUMULATIVE IAT & -325 & -6660 & -10070 & -14723 & -23564 & 14611 & 15364 & 26041 & 39871 & 55566 & 73091 & 92083 \\
\hline
\end{tabular}

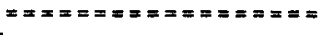




\section{$\underset{Y \text { VEAR }}{\text { VENTURE STATEMENT OF INCOME (BOOK) }}$

\section{YEAR}

METHANOL

BY-PRODUCTS $\begin{array}{rrrr}314044 & 324352 & 335370 \\ 27393 & 29036 & 30778\end{array}$

TOTAL REVENUE

199

19992000

2001

2002

2003

2004

2005

2006

$341437 \quad 353388$

366148

364304
32625

383910

$28970 \quad 454708$
38857

481991

43660

510910 46279

541565 49056

EX Г̄ENTESS

OPERATING

DEPRECIATION

INTEREST

OTHER EXPENSE ( 1 )

$180457 \quad 392986$

396929

18492441346

467827

$495897 \quad 525650$

552189

090621

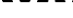

TOTAL EXPENSES

$34680 \quad 34680 \quad 306392 \quad 220736$

220736
236083

$\begin{array}{rrrr}236083 & 252505 & 270077 & 288881 \\ 34680 & 34680 & 34680 & 34680\end{array}$

34680
60168

330535

$34680 \quad 34680$

$353578 \quad 378239$

$34680 \quad 34680$

298517

750361

10983

1308

13866

19698

15580

2752

16510

17506

INCOME BEFORE TAX

92920

46451

49883

$70362 \quad 80582$

$90980 \quad 103812$

1.6957

130420

412981

$432295 \quad 453284$

\section{VENTURERS STATEMENT OF INCOME (BOOK)}

YEAR

$\begin{array}{llll}\text { INVESTMENT INCOME } & 42920 & 48451 & 49883 \\ \text { INCOME TAX } & 22177 & 24001 & 25774\end{array}$

$1998-1999$

$1999 \quad 2000$

$\begin{array}{lllllll}2000 & 2001 & 2002 & 2003 & 2004 & 2005 & 2006\end{array}$ INCOME TAX

$20450-0.000$ $36356 \quad 80582$ 41637.47009 $7009-53639$

INCOME AFTER TAX

$20743 \quad 22450 \quad 24108$

38945

CUMULATIVE IAT $112826 \quad 135276$

159384

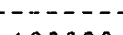

232335

43970

60431

0730

$67388 \quad 74513$

$\begin{array}{rrr}158325 & 172774\end{array}$

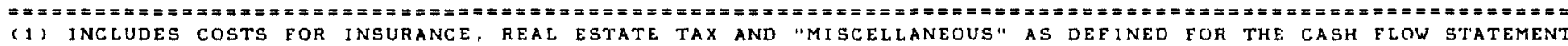




\begin{tabular}{|c|c|c|c|c|c|}
\hline VENTURE STA & $\underset{2007}{\text { IENT }}$ & $\begin{array}{r}\text { INCO } \\
2008\end{array}$ & $\begin{array}{l}180 \\
2009\end{array}$ & 2020 & TOTAL \\
\hline REVENUE & & & & & \\
\hline METHANOL & 608502 & 645012 & 683713 & 724736 & 9600545 \\
\hline BY-PRODUCTS & 55119 & 58426 & 61932 & 65648 & 846371 \\
\hline TOTAL REVENUE & 663622 & 703439 & 745645 & 790389 & 10496916 \\
\hline EXPENSES. & & & & & \\
\hline OPERATINC & 404632 & 432878 & 463110 & 495468 & 5938844 \\
\hline DEPRECIATION & 34680 & 34680 & 34680 & 39680 & 780304 \\
\hline INTEREST & 18195 & 13532 & 8868 & 7702 & 1245927 \\
\hline OTHER EXPENSE(1) & 18556 & 19669 & 20849 & 22100 & 378783 \\
\hline 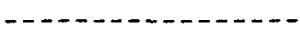 & $----n$ & $---\ldots$ & 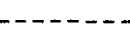 & 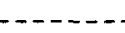 & -...-n \\
\hline TOTAL EXPENSES & 476063 & 500760 & 527508 & 559951 & 8343858 \\
\hline INCOME BEFORE TAX & 187559 & 202679 & 218137 & 230433 & 2103058 \\
\hline
\end{tabular}

\section{VENTURERS STATEMENT OF INCOME (BOOK)}

YEAR 200? 2008 2009 2010 TOTAL INVESTMENT INCOME 187559 202679 218137 230933 2103058 INCOME TAX $\quad 96912$ 104724 112711 119065 1021911 INCOME AFTER TAX 90697 97955 105426 111368 1081198 CUMULATIVE IAT $766399 \quad 864354969779 \quad 1081198$ (1) INCLUDES cOSTS FOR INS REAL EST TAX AND "MISCELLANEOUS" 


\begin{tabular}{|c|c|c|c|c|c|c|c|c|c|c|c|c|}
\hline YEAR & 1983 & 1989 & 1965 & 1986 & 1987 & 1988 & 1989 & 1990 & & & & \\
\hline INVESTMENT IN KEY & 9332 & 25445 & 67566 & 137441 & 196805 & 175944 & 144291 & 142220 & 139716 & 136963 & $\begin{array}{r}1993 \\
134262\end{array}$ & $\begin{array}{r}1994 \\
131616\end{array}$ \\
\hline TOTAL ASSETS & 9332 & 25445 & 67566 & 137941 & 196805 & 175944 & 144291 & 142220 & 139716 & 136963 & 139262 & 131616 \\
\hline DEFERRED INCOMETAX & 0 & 12937 & 29708 & 56345 & 84420 & 77638 & 153790 & 225240 & 296240 & 366792 & 348036 & 328831 \\
\hline NE'T WORTH & 9332 & 12508 & 37858 & 81097 & 112385 & 98306 & -9499 & -83019 & -156525 & -229829 & -213774 & -197215 \\
\hline TOTAL LIA SNET WTH & 9332 & 25445 & 67566 & 132441 & 196805 & 175944 & 144291 & 192220 & 139716 & 136963 & 134262 & 131616 \\
\hline
\end{tabular}

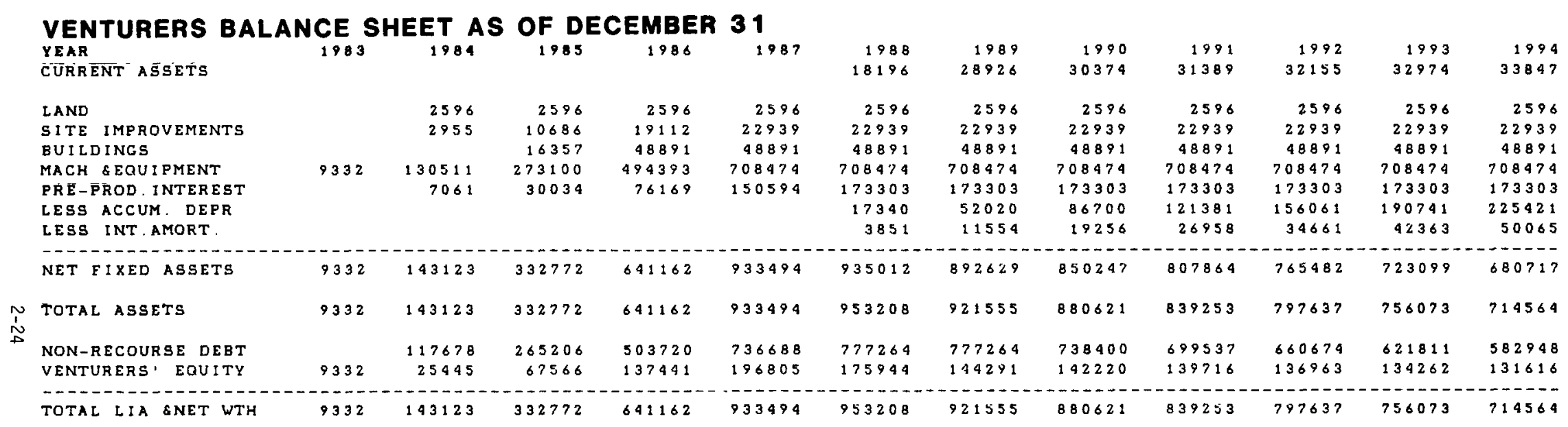


VENTURE BALANCE SHEET AS OF DECEMBER 31

\begin{tabular}{|c|c|c|c|c|c|c|c|c|c|c|c|c|}
\hline YYAR & 1995 & 1996 & 1999 & 1998 & 1999 & 2000 & 2001 & 2002 & 2003 & 2004 & 2005 & 2006 \\
\hline INVESTMENT IN KEY & 129030 & 126506 & 124050 & 123096 & 121374 & 119759 & 118946 & 117266 & 116226 & 115335 & 119602 & 114035 \\
\hline TOTAL ASSETS & 129030 & 126506 & 124050 & 123096 & 121374 & 119759 & 118446 & 117266 & 116226 & 115335 & 119602 & 119035 \\
\hline DEFERRED INCOMETAX & 309627 & 290422 & 271217 & 252012 & 232807 & 02 & 190 & & & 131394 & 109495 & \\
\hline NET WORTH & -180597 & -163915 & -147167 & -128916 & -111433 & -83843 & -75951 & $-5 ? 927$ & -37067 & -16059 & 5106 & 26439 \\
\hline rOTAL LIA SNET WTH & 129030 & 126506 & 124050 & 123096 & 121379 & 119759 & 118946 & 117266 & 116226 & 115335 & 114602 & 14035 \\
\hline
\end{tabular}

\section{VENTURERS BALANCE SHEET AS OF DECEMBER 31}

\begin{tabular}{|c|c|c|c|c|c|c|c|c|c|c|c|c|}
\hline YEAR & 1995 & 1996 & 1997 & 1998 & 1999 & 2000 & 2001 & 2002 & 2003 & 2004 & 2005 & 2006 \\
\hline CURRENT ASSETS & 34780 & 35776 & 36840 & 39405 & 41202 & 93106 & 45313 & 47652 & 50131 & 52760 & 55546 & 58499 \\
\hline LAND & 2596 & 2596 & 2596 & 2596 & 2596 & 2596 & 2596 & 2596 & 2596 & 2596 & 2596 & 2596 \\
\hline SITE IMPROVEMENTS & 22939 & 22939 & 22939 & 22939 & 22939 & 22939 & 22939 & 22939 & 22939 & 22939 & 22939 & 22939 \\
\hline BUILDINGS & 48891 & 48891 & 48891 & 48891 & 48891 & 48891 & 48891 & 48891 & 48891 & 48891 & 48891 & 48891 \\
\hline MACH. \&EQUIPMENT & 708474 & 708474 & 708474 & 708974 & 708474 & 708474 & 708474 & 708474 & 708474 & 708474 & 708974 & 708974 \\
\hline PRE-PROD. INTEREST & 173303 & 173303 & 173303 & 173303 & 173303 & 173303 & 173303 & 173303 & 173303 & 173303 & 173303 & 173303 \\
\hline LESS ACCUM. DEPR & 260101 & 294781 & 329462 & 364142 & 398822 & 933502 & 468182 & 502863 & 537543 & 572223 & 606903 & 641583 \\
\hline LESS INT AMORT. & 57768 & 65470 & 73172 & 80875 & 88577 & 96280 & 103982 & 111684 & 119387 & 127089 & 134781 & 142494 \\
\hline 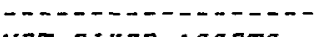 & $--\cdots-1$ & ---- & & - & 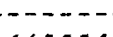 & & $-\cdots--$ & - & & & & 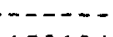 \\
\hline NET FIXED ASSETS & 638339 & 595951 & 553569 & 511186 & 468804 & 926421 & 384039 & 341656 & 299274 & 256891 & 214509 & 172126 \\
\hline TOTAL ASSETS & 673114 & 631728 & 590408 & 550591 & 510005 & 469527 & 429352 & 389308 & 349405 & 309651 & 270054 & 230625 \\
\hline NON-RECOURSE DEET & 544085 & 505221 & 466358 & 427495 & 388632 & 349769 & 310905 & 272042 & 233179 & 194316 & 155453 & 116590 \\
\hline VENTURERS ' EQUITY & 129030 & 126506 & 124050 & 123096 & 121374 & 119759 & 118446 & 117266 & 116226 & 115335 & 114602 & 119035 \\
\hline TOTAL LIA ENET WTH & 673114 & 631728 & 590408 & 550591 & 510005 & 469527 & 429352 & 389308 & 349405 & 309651 & 270054 & 230625 \\
\hline
\end{tabular}




\begin{tabular}{|c|c|c|c|c|}
\hline \multirow{2}{*}{\multicolumn{5}{|c|}{ VENTURE BALANCE }} \\
\hline & 2007 & 2008 & 2009 & 2010 \\
\hline CURRENT ASSETS & 61629 & 69947 & 68464 & 0 \\
\hline LAND & 2596 & 2596 & 2596 & 2596 \\
\hline SITE IMPROVEMENTS & 22939 & 22939 & 22.939 & 22939 \\
\hline BUILDINGS & 48891 & 48891 & 48891 & $A B B 91$ \\
\hline MACH \&EQUIPMENT & 708474 & 708474 & 708474 & 708474 \\
\hline PRE-PROD INTEREST & 173303 & 173303 & 173303 & 173303 \\
\hline LESS ACCUM DEPR & 676263 & 710944 & 745624 & 780304 \\
\hline LESS INT AMORT & 150196 & 157898 & 165601 & 173303 \\
\hline NET EIXED ASSETS & 129744 & 87361 & 94979 & 2596 \\
\hline TOTAL ASSETS & 191373 & 152308 & 113443 & 2596 \\
\hline NON-RECOURSE DEBT & 77726 & 38863 & 0 & 0 \\
\hline VENTURERS' EQUITY & 113646 & 113495 & 113443 & 2596 \\
\hline TOTAL LIA SNET WTH & 191373 & 152308 & 113443 & 2596 \\
\hline
\end{tabular}

\section{VENTURERS BALANCE SHEET AS OF DECEMBER 31}

\begin{tabular}{|c|c|c|c|c|}
\hline YEAR & 2007 & 2008 & 2009 & 2010 \\
\hline INVESTMENT IN KEY & 113646 & 113445 & 113443 & 2596 \\
\hline JTAL ASSETS & 113646 & 113495 & 113943 & 2396 \\
\hline EFERRED INCOMETAX & 65697 & 93798 & 21899 & 0 \\
\hline ET WORTH & 47949 & 69647 & 91544 & 2596 \\
\hline DTAL IIA \&NET WTH & 113646 & 113945 & 113443 & 2596 \\
\hline
\end{tabular}




\section{FINANCIAL EXPOSURE TO VENTURERS}

END OF YEAR $1983 \quad 1984 \quad 1985$

CASH FLOW-CUM $9657-19168$ 97927

TAY SAVING DII LOSS

ITC RECAPTURE ON

AEANDONMENT

TAX DUE/LOAN ( 1 )

$\begin{array}{rrr}9657 & -19168 & 97927 \\ 4922 & 73951 & 171943\end{array}$

$1986 \quad 1987$

$\begin{array}{rr}1986 & 1987 \\ -95820 & -135949\end{array}$

$1988 \quad 1989$

$\begin{array}{rrrrrr}1989 & 1990 & 1991 & 1992 & 1993 & 1999 \\ 24862 & 109061 & 196396 & 283395 & 286868 & 289298\end{array}$

428034

325473

227614

$130204 \quad 283395 \quad 286866$

89298

TOTAL EXPOSURE

$12937 \quad 29700$

$\begin{array}{llll}345 & 84420 & 87291 & 69833\end{array}$

$\begin{array}{rrrrrrrr}84420 & 87291 & 69833 & 52375 & 34916 & 17458 & & \\ 380647 & 901612 & 901612 & 381531 & 361451 & 391370 & 321290 & 301209\end{array}$

$69833 \quad 52375 \quad 34916 \quad 17458$

$\begin{array}{rrrrrrrr}84420 & 87291 & 69833 & 52375 & 34916 & 17458 & & \\ 380647 & 901612 & 901612 & 381531 & 361451 & 391370 & 321290 & 301209\end{array}$

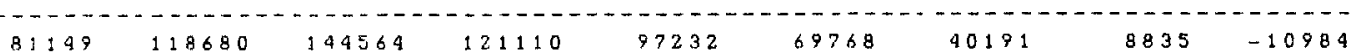

END OF YEAR

CASH FLOW-CUM

TAX SAVINC ON LOSE

ITC RECAPTURE ON

AEANDONMENT

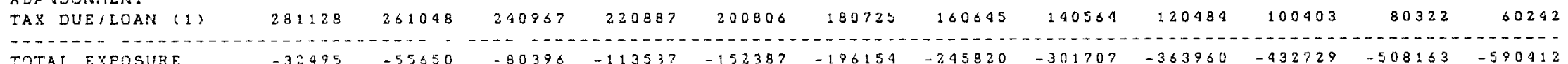

$\stackrel{y}{\stackrel{1}{n}}$

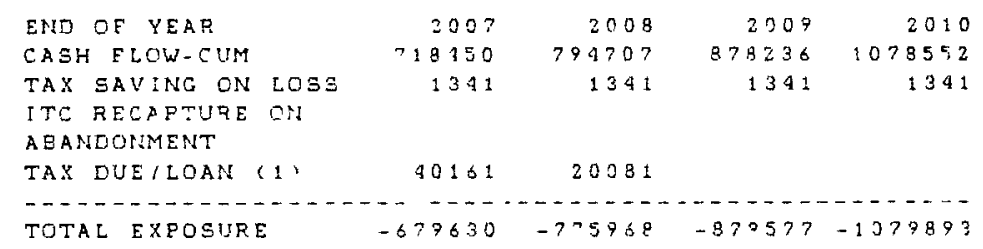

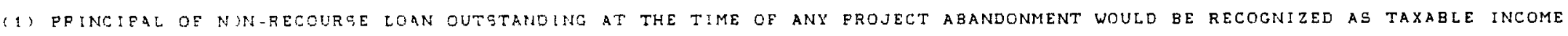
THEREBY CREATING A TAX LIABILITY 


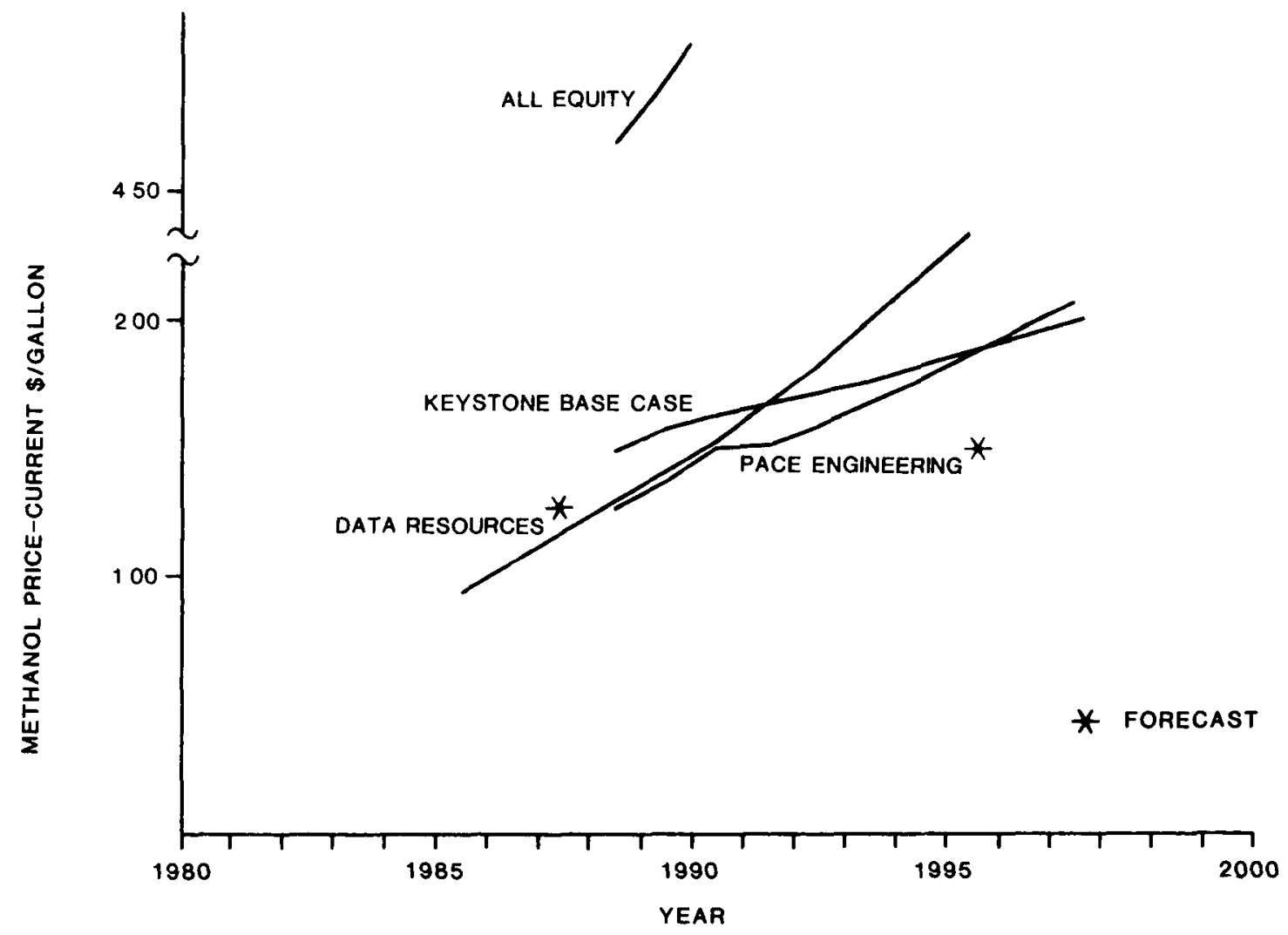

Figure 2-1 Comparison of Methanol Prices 
the more conservative PACE forecast in 1996, demonstrating the probable economic long-term viability of the project following the initial SFC assistance.

\subsection{SENS ITIVITY ANALYS IS}

A sensitivity analys is was performed on the base case to determine the effect of variations from expected values of certain factors that can influence the profitability of the project. During the analysis, only one parameter was varied at a time so its effect could be determined independently of the others.

The parameters selected for the sensitivity analys is included:

- Plant capacity factor (steady-state)

- Thermal efficiency

- Interest rates

- Coal price (delivered)

- Coar and electricity escalation

- Labor escalation and general inflation

- Capital cost

- Capitar cost escalation

- Construction schedule delay

A reasonable range of variation around the base case value for each parameter was used for the investigation.

Table 2-6 displays the results of the sensitivity analys is in two ways: (1) the impact on the rate of return using the base case methanol support price, and (2) the effect on the January 1982 methanol support price required to achieve a 30 percent rate of return through the support period.

The results indicate that variations in plant capital cost, capacity factor, thermal efficiency and short-term interest rates can significantly affect the project's financial performance. Relatively small percentage changes in these variables produce significant changes in the rate of return. On the other hand, the rate of return is much less sensitive to the cost of delivered coal. 
TABLE 2-6

SENSITIVITY ANALYSIS

\begin{tabular}{|c|c|c|c|c|c|}
\hline Parameter & Base & Case Value & Variation & $\begin{array}{l}\text { DCFROR Through } \\
1997 \text { with } \\
\$ 1.07 \text { per gallon } \\
\text { Base Price } \\
\end{array}$ & $\begin{array}{l}1982 \text { Methanol Base } \\
\text { Price to Realize 30\% } \\
\text { DCFROR Through } 1997\end{array}$ \\
\hline Base Case & & -- & -- & $30 \%$ & $\$ 1.07$ per gallon \\
\hline $\begin{array}{l}\text { Capacity factor } \\
\text { (steady-state) }\end{array}$ & After & $\begin{array}{ll}1988 & 58 \% \\
1989 & 79 \% \\
1990 & 81 \% \\
1990 & 82 \%\end{array}$ & $\begin{array}{l}58 \% \\
86.7 \% \\
88.9 \% \\
90 \%\end{array}$ & 33 & 1.01 \\
\hline & After & $\begin{array}{ll}1988 & 58 \% \\
1989 & 79 \% \\
1990 & 81 \% \\
1990 & 82 \%\end{array}$ & $\begin{array}{l}58 \% \\
77.1 \% \\
79 \% \\
80 \%\end{array}$ & 29 & 1.08 \\
\hline Thermal efficiency & \multicolumn{2}{|r|}{$56.2 \%$} & $58.2 \%$ & 32 & 1.03 \\
\hline & \multicolumn{2}{|r|}{$56.2 \%$} & $54.2 \%$ & 28 & 1.11 \\
\hline \multirow[t]{3}{*}{ Interest rates } & \multirow[t]{3}{*}{$\begin{array}{l}\text { Short } \\
\text { Long }\end{array}$} & \multirow[t]{3}{*}{$\begin{array}{l}\text { (S) } 12 \% \\
\text { (L) } 12 \%\end{array}$} & $\begin{array}{l}\text { (S) } 12 \% \\
\text { (L) } 15 \%\end{array}$ & 30 & 1.07 \\
\hline & & & $\begin{array}{lr}\text { (S) } & 12 \% \\
(L) & 9 \%\end{array}$ & 30 & 1.07 \\
\hline & & & $\begin{array}{l}\text { (S) } 15 \% \\
\text { (L) } 15 \%\end{array}$ & 23 & 1.21 \\
\hline
\end{tabular}


TABLE 2-6

(continued)

\section{SENSITIVITY ANALYSIS}

Parameter

Interest rates (cont.)
Base Case Value

Variation

(S) $9 \%$

\section{Coal price}

(delivered)

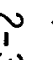

$\begin{array}{lll}\stackrel{\sim}{\omega} \text { Coal (C) \& electricity (E) } & 1982-1990 & \text { (C) } 9 \% \\ \text { price escalation } & \text { (E) } 8 \% \\ & 1990-2010 & \text { (C) } 7 \% \\ & & \text { (E) } 7.5 \%\end{array}$

As above
DCFROR Through

1997 with

$\$ 1.07$ per gallon

Base Price

35

\subsection{6}

1982 Methanol Base

Price to Realize $30 \%$

DCFROR Through 1997 
TABLE 2-6

(continued)

\section{SENSITIVITY ANALYSIS}

Parameter

Capital cost (\$ millions)

Base Case Value

547 (January 1982)

783 (escalated)

As above
DCFROR Through

1997 with

$\$ 1.07$ per gallon Base Price

$493(-10 \%)$

705

$657(+20 \%)$

939
33

1982 Methan.11 Base

Price to Realize $30 \%$ DCFROR Through 1997

1.00

20

1.29

ĩ

W Capital cost escalation

$9 \%$

$11 \%$

28

1.10

$9 \%$

$7 \%$

30

1.07 
The formula for the required methanol price insulates the project from some of the variations and uncertainties in future escalation and interest rates. Table 2-6 shows that there is no change in the support price and the rate of return with a rise or fall in four areas: (1) coal and electricity cost escalation, (2) labor and general cost inflation, (3) long-term interest rate relative to an assumed short-term rate of 12 percent, or (4) capital cost escalation decreases. This insensitivity is attributable to the compensating adjustment to the escalation of the support price provided by the formula. An increase in construction cost escalation is not fully offset by the formula only because it causes an overrun of the estimated pre-production costs, and it is assumed that any such overrun would receive only a 50 percent loan guarantee rather than 75 percent, thereby increasing the proportion of more costly equity financing.

Because of the critical sensitivity of project returns to capital cost, capacity factor and thermal efficiency, all of which can be controlled by proper business and technical management, project management must be highly concerned with planning, monitoring and mitigating such risk factors. Understanding the source of greatest risks to the project has provided the basis for developing and implementing the risk management program described in Section 1.0 of this volume.

A significant decrease in the rate of return required by the equity investors during the price support period from the 30 percent assumed elsewhere in this study would result in large reductions in the required assistance level. If market prices are projected to be only 80 percent of the PACE forecast, then the anticipated support formula base price and consequent price support payments corresponding to various rates of return are shown in Table 2-7.

\subsubsection{OPTIMISTIC AND PESSIMISTIC CASES}

Two additional cases were also run: (1) an optimistic case, in which numerous parameters were simultaneously considered to fall at the favorable end of the range of likely results, and (2) a pessimistic case, in which they uniformly fell at the unfavorable end. The assumptions that defined these two cases are presented in Table 2-8. The purpose was to bracket the range of final outcomes that could be expected. 


\section{TABLE 2-7}

EFFECT OF TARGET RATE OF RETURN ON REQUIRED PRICE SUPPORTS

\begin{tabular}{|c|c|c|c|}
\hline $\begin{array}{l}\text { Rate of Return } \\
\text { through } 1997 \\
\end{array}$ & $\begin{array}{c}\text { Support Formula } \\
\text { Base Price } \\
(1 / 82 \text { S/Gal.) } \\
\end{array}$ & $\begin{array}{l}\text { Reduction in Base } \\
\text { Price from Case with } \\
30 \% \text { Rate of Return } \\
\end{array}$ & $\begin{array}{c}\text { Price Supports } \\
\text { with Market a } \\
\text { 80\% of PACE Forecast } \\
\text { (Thousands of Current } \$ \text { ) } \\
\end{array}$ \\
\hline $\begin{array}{l}30 \% \\
25 \% \\
20 \% \\
15 \%\end{array}$ & $\begin{array}{l}\$ 1.07 \\
0.98 \\
0.91 \\
0.86\end{array}$ & $\begin{array}{l}-. \\
8.4 \% \\
15.0 \% \\
19.6 \%\end{array}$ & $\begin{array}{r}\$ 667,311 \\
427,937 \\
248,260 \\
131,502\end{array}$ \\
\hline
\end{tabular}


TABLE 2-8

MODIF I CATION OF BASE CASE ASSUMPT IONS

FOR THE OPTIMISTIC AND PESS IMISTIC CASES

\begin{tabular}{|c|c|c|c|c|}
\hline Parameter & Base Case & & $\begin{array}{c}\text { Optimistic } \\
\text { Case } \\
\end{array}$ & $\begin{array}{c}\text { Pessimistic } \\
\text { Case } \\
\end{array}$ \\
\hline \multirow[t]{4}{*}{ Capacity factor } & 1988 ( 9 mo ): & $58 \%$ & $58 \%$ & $50 \%$ \\
\hline & 1989: & $79 \%$ & $86.7 \%$ & $70 \%$ \\
\hline & 1990: & $81 \%$ & $88.9 \%$ & $78 \%$ \\
\hline & After 1990: & $82 \%$ & $90 \%$ & $80 \%$ \\
\hline Thermal efficiency & $56 \%$ & & $58 \%$ & $54 \%$ \\
\hline Capital costs & -- & & $-10 \%$ & $+20 \%$ \\
\hline \multicolumn{5}{|c|}{ Operating \& maintenance } \\
\hline costs & -- & & $-10 \%$ & $+10 \%$ \\
\hline \multicolumn{5}{|l|}{ Interest rates: } \\
\hline Short-term & $12 \%$ & & $9 \%$ & $15 \%$ \\
\hline Long-term & $12 \%$ & & $9 \%$ & $15 \%$ \\
\hline \multicolumn{5}{|c|}{$\begin{array}{c}\text { Escalation of capital, } \\
\text { coal, electricity, }\end{array}$} \\
\hline inflation rates & -- & & $-1 \%$ & $+2 \%$ \\
\hline
\end{tabular}


Table 2-9 presents the relative results from the optimistic and pessimistic cases compared with those from the base case. The range in methanol support prices required, the base case prices and the PACE and DRI price forecasts are depicted in Figure 2-2.

There are several reasons for the greater deviation from base case results of the pessimistic evaluation, which increased the required January 1982 support price by $52 \not k$ per gallon, compared with the optimistic case, which decreased it by $25 \not$. The primary explanation was the asymmetric range of capital costs selected, being 20 percent higher relative to the base value for the pessimistic case and 10 percent lower for the optimistic case. This asymmetry reflects the fact that when there are overruns, they tend to be more significant than underruns. Secondly, the overrun and interest costs attributable thereto are assumed to be funded with only 50 percent leverage, a consideration absent in the case of an underestimate. It can be seen from the results of the sensitivity analys is (Table 2-6) that a 10-percent capital cost reduction lowers the January 1982 support price by $7 \not$ per gallon, whereas a 20-percent overrun increases it by $22 k$, an impact greater by $15 k$.

\subsection{PROJECT FINANCING PLAN}

The risks and future price uncertainties of the Keystone Project mean that project feasibility depends on the availability of significant financial assistance from the SFC. As previously discussed, the most viable approach involves the receipt of both loan and price guarantees.

The SFC is also authorized to make direct loans as well as enter into purchase agreements and joint ventures. However, because of the manner in which the SFC's enabling legislation is drafted, and because of the more significant budgetary impacts of these forms of assistance, it is unlikely that these approaches will be used at this time by the SFC.

In January 1983, the Keystone Project submitted a proposal to the SFC under their Third Solicitation. In this proposal, the project concluded that the final financing plan should involve a combination of loan guarantees and price supports as defined below. The project's size will keep the total SFC financial obligation well below the statutory limit for a single project. 
TABLE 2-9

COMPAR ISON OF RESULTS FROM BASE CASE, OPTIMISTIC CASE AND PESSIMISTIC CASE

DCFROR to 1997 DCFROR to 2010 Methanol Price a \$1.07 per Gal @ \$1.07 per Gal for 30 Percent

Base case Methanol Price*

Optimistic case 30 percent Methanol Price* DCFROR through 1997*

Pessimistic case 41 percent 31 percent $\$ 1.07$ per gallon Negative 42 percent 0.82 Negative $\quad 1.59$

‡ January 1982 price. 


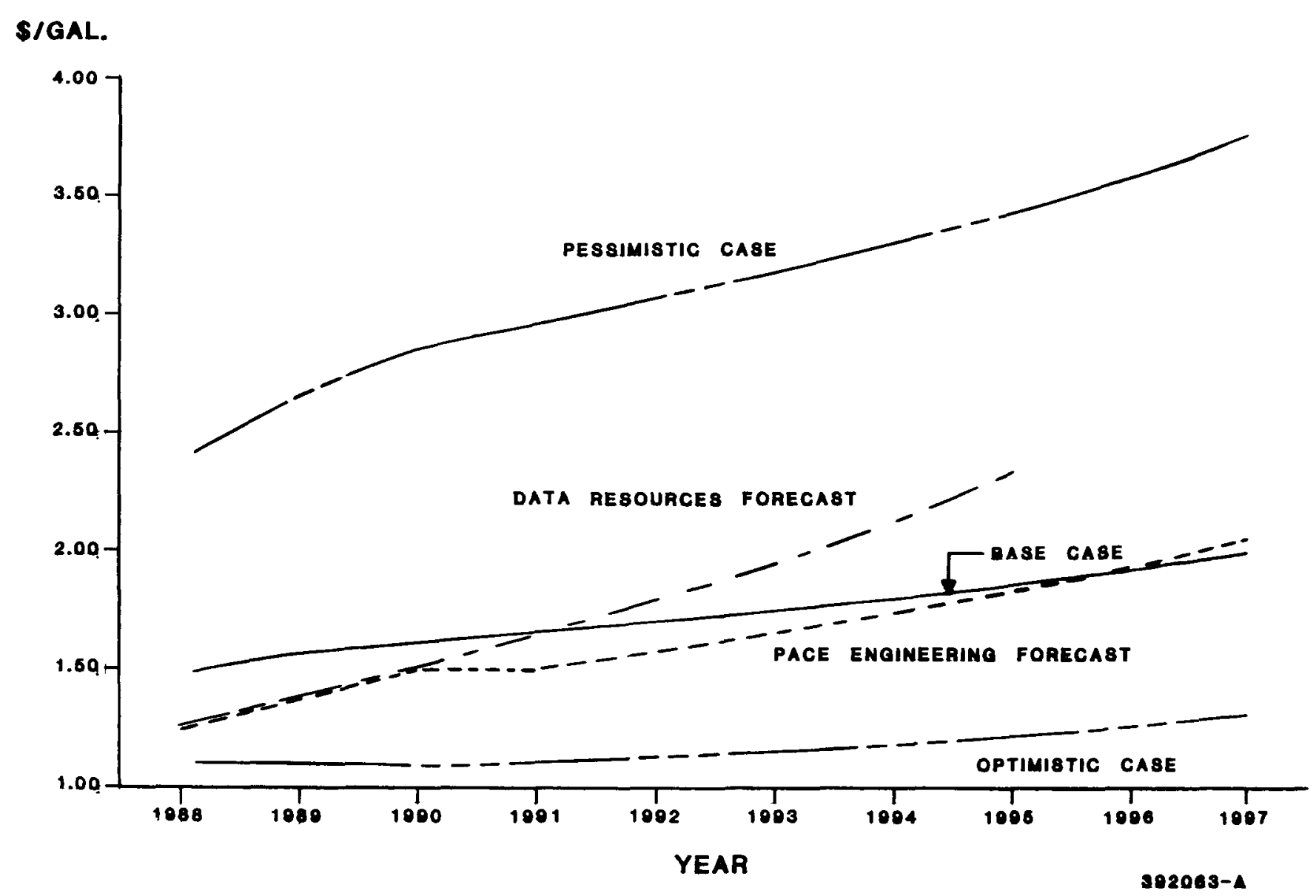

Figure 2-2 Methanol Price by Year During Price Support Period 


\subsubsection{LOAN GUARANTEE}

Loan guarantee authority of $\$ 777,264,000$ in completed dollars has been requested from the SFC. This amount represents estimated SFC exposure and may be revised upward or downward, as further engineering is performed on the project prior to contractual agreement.

During construction, the total project cost will be financed by 25 percent sponsor equity and 75 percent guaranteed project notes with a trustee holding the guarantee, or, alternatively, through commercial paper backed by a commercial bank line of credit, with the commercial bank holding the loan guarantee. The construction debt will be refinanced at approximately the time of commencement of operations. The project assets will provide the full collateral for the guaranteed loans. The principal of the long-term debt will be repaid semiannually, over a 20-year period, with equal payments together with accrued interest.

\subsubsection{PRICE SUPPORT}

Using the current plant cost estimate, the price support formula previously given and the PACE Engineering projection of future methanol price, the total requested price guarantee authority is $\$ 149,692,000$. The specific bas is for price support analys is will be contingent on the price that methanol commands in the markets into which it is sold. Market analys is has indicated that there are significance differences in the value of methanol to different potential users and, consequently, the market clearing price will be different. As the project is more fully developed, the exact bas is for the total price support will be established in negotiations with the SFC.

The general nature of available financial assistance from the SFC and the potential applicability of each of these forms of assistance to the Keystone Project are discussed in the following subsections. 


\subsection{AVAILABLE FINANCIAL ASS ISTANCE FROM THE SFC}

The government synthetic fuels program is currently embodied in the SFC, which was authorized and established by the Energy Security Act (Public Law No. 96-294) passed in July 1980. Funding for the SFC is provided through Public Law No. 96-304 and a series of subsequent clarifying appropriations acts. The Energy Security Act establishes specific forms of authority for providing financial assistance and sets goals and priorities for the SFC.

The SFC currently has available $\$ 14.9$ billion in obligational authority. Of this total, $\$ 6$ billion in funds has been allocated by the Board of Directors for coal projects. For each project, the maximum liability of the SFC is stipulated in a contract and can only be increased through later award of additional authority. If additional authority is unavailable from the SFC, any increase in authority would require a congressional appropriations act.

The Energy Security Act establishes the maximum total financial liability of the SFC to a single project at any point in time at $\$ 3$ billion. This limit includes any past payments to the project and is not affected by awards that combine more than one type of incentive, such as loan and price guarantees. The authorizing legislation also provides that each contract for financial assistance specify the maximum liability of the SFC with respect to that individual award.

Projects receiving more than one form of financial assistance must meet a higher standard than those receiving a single form of financial assistance. The SFC Board of Directors must determine that more than one form of financial assistance is required for the viability of a project and, further, that the specific project is necessary to achieve the purposes of the Energy Security Act.

The following subsections describe the various forms of assistance available from the SFC. 


\subsubsection{SFC LOAN GUARANTEES}

The SFC has the authority to guarantee 100 percent of the principal of loans approved by the SFC. Such guarantees cannot exceed 75 percent of the initial estimated cost of the project. The SFC also has the authority to finance cost overruns beyond the amount of the total project cost specified in the initial award but at a decreasing percentage of the overrun. The SFC can finance, through loan guarantees, up to 50 percent of cost overruns in excess of the initial total estimated cost, provided that the revised total estimated cost does not exceed 200 percent of the initial cost. Once the revised cost exceeds 200 percent of the initial estimated cost, the SFC may finance only up to 40 percent of the additional overrun. If the overrun exceeds 250 percent of the initial estimated cost, the SFC may not provide any additional loan guarantee authority to the project unless the SFC indicates its intent to Congress, and Congress does not disapprove this action.

Loan guarantees made by the SFC are full faith and credit guarantees. Such a guarantee is important to lenders in that the federal government is the ultimate creditor, beyond the SFC. The Energy Security Act further provides that the guarantee cannot have a maturity of more than 30 years, or the useful life of the synthetic fuels project, whichever is less. The enabling legislation also provides that a loan guarantee can be made to one and not all of the project's sponsors.

Loan guarantees are of particular importance because they allow the project to have true non-recourse financing without direct or indirect liability of the sponsors for the debt. The degree of risk that the SFC is willing to accept under the non-recourse structure must be negotiated. It remains to be determined to what degree market purchase contracts and the provisions of those contracts would be required.

\subsubsection{SFC PRICE GUARANTEES}

The Energy Security Act requires that price guarantees not be based on a cost-plus arrangement or any variation thereof that guarantees a profit to the project. The law specifically excludes a cost-of-service tariff from the 
definition of cost-plus types of loan guarantees. The SFC, in awarding price guarantee contracts, must also establish a specified sales price at the level that would provide the minimum subsidy determined by the SFC to be necessary to provide adequate incentive for the project.

The law provides that as a condition for providing the price guarantee, the SFC may require its share in the profits of a project on a fair basis. The Energy Security Act requires that any price guarantee include a provision to the effect that "the price guarantee or purchase agreement shall be subject to review and possible renegotiation within 10 years from the date of initial production by the Synthetic Fuels Project, at which point the SFC shall specifically determine the need for continued financial assistance pursuant to such price guarantee or purchase commitment."

\subsubsection{SFC PURCHASE AGREEMENTS}

Although the Energy Security Act gives the SFC the authority to enter into a purchase agreement, the effect of the Act is that purchase agreements are similar to price guarantees. This results from a requirement under the legislation that a purchase agreement or commitment must retain the SFC's right to refuse delivery of the synthetic fuel under such terms and conditions as are specified in the purchase agreement. This contractual right to refuse delivery means that the SFC can effectively guarantee only price for the fuel and not the market.

Purchase agreements could conceivably be available from the Department of Defense or other government agencies with the price guaranteed by the SFC. However, no government agency, including the Department of Defense, purchases methanol. Purchases of gasoline for motor vehicle use by the Department of Defense is not conducted on a centralized basis. Centralized methanol purchases for blending with gasoline are not possible. Therefore, SFC purchase agreements are not a viable option for this project. 


\subsubsection{SFC DIRECT LOAN AUTHORITY}

In addition to loan guarantees, the SFC is authorized to enter into direct loan agreement for a synthetic fuels project. Such loans have similar provisions to those of the loan guarantee authority except that direct loans are further limited to the lesser of 49 percent of the initial total estimated project cost or not more than a minority financial interest in the project, unless the SFC Board of Directors determines that the borrower has satisfactorily demonstrated that such limits would prevent the financial viability of the proposed project, therefore necessitating additional loan assistance.

A direct loan would not necessarily be issued at an interest rate lower than that of a loan guarantee. Each loan is required to bear interest at a rate determined by the SFC, taking into account the needs and capacity of the recipient and prevailing rates of interest. However, the 1 aw provides that such interest shall not be at rates less than those determined by the Secretary of Treasury, taking into consideration current yields on outstanding obligations of the United States.

The disadvantage to the SFC of a direct loan is that when it makes such a loan, the amount counts as a budget outlay for the government, contributing to the federal budget deficit. Loan guarantees do not count against the federal budget unless a payment is made against a defaulted loan.

\section{8 .5 SFC JOINT VENTURES}

Joint ventures by the SFC are restricted to a synthetic fuels project module that (1) demonstrates the commercial feasibility of the technology, and (2) can be expanded into a synthetic fuel project. The law further states that the initial contract may provide for purchase, pursuant to such joint venture agreement, of the equity interest by the project sponsor at an interval not to exceed 5 years after the date of operation. The law also states that the SFC cannot finance more than 60 percent of the total cost of the symthetic fuel module as estimated by the SFC at the time of the execution of the joint venture agreement. 
As was shown earlier, tax benefits from the Keystone Project provide a major part of the return to investors. This return results from the benefits the equity sponsors receive from the leveraged project. Under a joint venture, the project would have to be carefully structured so that private participants receive the full value of the project's tax benefits.

The Keystone Project would be eligible for consideration as a joint venture, but the law places joint ventures at a much lower priority for assistance than loan guarantees and price guarantees.

\subsection{SFC SOLICITATION REQUIREMENTS}

The SFC is required by 1 aw to issue solicitations and have projects compete for funds. Three solicitations have been issued by the SFC to date in the form of general solicitations. Subsequent solicitations will be in the form of specially tailored solicitations.

In the general solicitations, the competition has been conducted by having projects meet two sets of criteria, maturity and strength criteria. The maturity criteria measure project definition and the degree to which project costs can currently be analyzed. The strength criteria measure the degree of private commitment to the project and the cost of required assistance to the SFC. The strength test also imposes a requirement that the project reach a certain level of design in a specified time period.

Funds spent prior to a definite SFC commitment are the highest risk capital of a project and because of the need for government assistance, represent a more risky investment than equivalent expenditures for a project where the decision to proceed is not controlled by outside parties. To mitigate this risk, the SFC has authority under Section $131(u)$ of the Energy Security Act to share in the costs of engineering necessary to refine cost estimates, up to 1 percent of total project costs.

Availability of Section 131(u) funds for front-end engineering work would greatly enhance the attractiveness of the Keystone Project to outside investors. 
The SFC has issued its first letter of intent to the Peat Methanol Associates (PMA) partnership. This letter of intent provides insight into the manner in which the SFC will approach financial assistance for the Keystone Project. A Summary Term Sheet for the PMA project is given in Table 2-10. The general approach taken by the SFC uses requirements under the Energy Security Act that affect the maximum amount of financial assistance provided. However, during the term of the project, the form of assistance can be rolled over between loan guarantees and price guarantees.

\subsection{PROJECT STRUCTURE OPTIONS}

The financial structure options available to a synthetic fuels project like Keystone are principally determined by the tax benefits available. If the project is financed on a non-recourse basis with a government guarantee, investors receive tax credits and other tax benefits on an asset base larger than their investment in the project without bearing the full risk of project loss.

\subsubsection{TAX BENEFITS}

The tax benefits under the project are the 10-percent Investment Tax Credit and accelerated depreciation deductions during operations. Most of the project's assets would be 5-year property for both tax credits and accelerated depreciation purposes.

A1though the 10-percent Energy Tax Credit was enacted to stimulate investment in alternative fuels, this credit was only available if by January 1, 1983, (1) a11 engineering studies had been completed in connection with construction, (2) the project had applied for all environmental and construction permits, and (3) before January 1, 1986, the project had entered into binding contracts for the acquisition, construction or erection of equipment specially designed for the project with the aggregate cost of that equipment being at least 50 percent of the cost for all such project equipment. The keystone Project did not meet this timetable. 


\section{PEAT METHANOL ASSOCIATES (PMA) SUMMARY TERM SHEET}

USE OF PROCEEDS

FORM AND AMOUNT OF FINANCIAL ASSISTANCE

CAPITAL STRUCTURE

METHANOL SUPPORT PRICE
To construct and operate a 60 million gallon-per-year peat-to-methanol facility in North Carolina. The project has an estimated total cost of $\$ 576$ million (including contingencies of $\$ 85$ million).

Total financial liability of the SFC has a maximum limit of $\$ 465$ million, of which guaranteed debts, including accrued interest, are not to exceed $\$ 366$ million. An additional $\$ 50$ million of guaranteed debt may be temporarily issued which would facilitate refinancing of construction debt or provide a mechanism to cover "preference" concerns of commercial paper purchasers. Price guarantee author ity commences at $\$ 99$ million and can increase to a total of $\$ 440$ million as outstanding guaranteed debt is repaid or refunded by non-guaranteed debt.

The initial $\$ 491$ million of project costs will be funded through 62.2 percent SFC-guaranteed debt, 12.8 percent non-guaranteed debt and 25 percent equity. The next $\$ 48$ million will be funded by 25 percent equity and 75 percent SFC-guaranteed debt. The balance of project costs, up to the total $\$ 576$ million, will be funded by equity. Under such circumstances, the project would be funded by $\$ 341$ million guaranteed debt, $\$ 63$ million non-guaranteed debt and $\$ 173$ million equity.

For up to 15 years (or upon election, 10 years, as explained below), the SFC will make monthly support payments to PMA for each gallon of methanol produced where the market price exceeds the support price. The support price commences on January 1, 1983, at \$1.05 per gallon and is adjusted for inflation plus an additional 2 percent increase per annum. This formula is subject to re-negotiation 10 years after commencement of operation. Alternatively, the SFC may elect the price of $\$ 1.23$ per gallon adjusted only for inflation. Under this selection, the price guarantee would be for a period of only 10 years. 
MARKETING AGREEMENT

REPAYMENT OF PRICE SUPPORTS

COST-SHAR ING AGREEMENT

FEES

LIAB IL ITY OF SPONSORS
PMA will enter into a marketing agreement for 50 percent of the first five years production where the methanol price (P) will be based on the formula:

$P(\$ / g a l i o n)=\frac{\text { NYHL }}{1.5}-T+.20$

where NYHL - - is the New York Harbor Leaded Gasoline Price (\$/galion)

T

-- is the transportation differential between New York and North Carol ina (currently estimated at $\$ 0.03 /$ gallon)

-- is $1 / 2$ of the alcohol fuel tax credit (peat is considered biomass and is eligible for this tax credit)

For up to 17 years after commencement of operation (12 years under the 10 year election), price supports will be repaid out of 50 percent of the excess of amounts arising when the support price is less than the market price (limited to 50 percent of the excess of cash flow after payments to a debt protection fund). Total repayment is limied to the $h$ igher of $\$ 210$ million or the aggregate of payments made to PMA. Repayments shall increase by a specified amount should interest during construction by deductible from current income taxes .

By January 1, 1983, the SFC and PMA intend to negotiate a cost-sharing agreement under Section 131 (u) of the Energy Security Act to perform additional work to refine current estimates of construction and operating costs for the project. The effort will be funded on a bas is of 51 percent by PMA and 49 percent by the SFC up to a maximum of $\$ 4.65$ million. It is intended that all work under this agreement be completed by March 1, 1983.

Ass istance fee of $\$ 1,162,500$ will be paid to the SFC at closing. Guarantee fee of 0.5 percent per annum will be paid on SFC debt outstanding.

Sponsors will commit to provide up to $\$ 172$ million of equity and further commit to undertakings required to obtain $\$ 63$ million in non-guaranteed debt. 
TABLE 2-10

(continued)

Sponsors are further liable for amounts totaling the pro rate share of the full aggregate guaranteed principal and interest outstanding where the sponsors knowingly, intentionally or negligently make material misrepresentations, omissions, breach of covenants or certain other actions. Sponsors must warrant at execution of the agreements, for any drawdown under the guaranteed loan, that the sponsor bel ieves there exists reasonable assurance of timely repayment of the guaranteed debt. This warranty is subject to liability of an amount varying in total from $\$ 60$ million to $\$ 35$ million as equity is paid in.

If the project were abandoned, even after the 5-year accelerated depreciation tax credit period, there could be further tax consequences to the sponsors arising from default under the non-recourse loan guarantee. The question as to whether there would be taxable income to project sponsors under such a default situation is currently under review by the United States Supreme Court. PMA has agreed to treat the project under the least favorable ruling currently pending and has agreed to pay the SFC an amount equal to the tax liability that would not otherwise be incurred if the Supreme Court were to decide this issue on a more favorable bas is. 
Interest on debt during construction is currently deductible to the extent it is used to fund assets other than "real property." The Keystone Project has assumed that all assets are "real property." Therefore, debt interest has been capitalized and depreciated under a 266 election.

\subsection{0 .2 ORGANIZATIONAL OPTIONS}

The project can be organized as a corporation, a partnership or a joint venture. A corporation is not recommended because no sponsor will own the 80 percent share required to file a consolidated tax return and take the project's tax benefits when they are available. The typical form of a project of this nature is a joint venture of the participants. A partnership would be appropriate for the project if, by virtue of the tax status of participants or the changing role of a participant, there is a need to enter into a formal partnership agreement. Under this structure, the partners would be 80 - to 100-percent owned subsidiaries of the project sponsors.

Under a joint venture, a subsidiary corporation of each of the sponsors would typically be the venturer. The obligation of each of the sponsors would be set forth in an operating agreement that would appoint one sponsor as the project operator. This agreement would provide for sharing of expenses, allocations of production or revenues, assumptions of the obligations of a defaulting partner and a voting method for making major project decisions and changes. The existence of an operating agreement of this type is one measure of project maturity under the SFC evaluation process.

\subsection{0 .3 OWNERSHIP OPTIONS}

Within the project structure, the clear option exists to separately own and finance certain assets. The most likely assets to be treated this way are the air separation plant and the coal handling equipment.

Air Products and Chemicals Inc. has proposed a mechanism for separately supplying oxygen to the project under a take-or-pay contract that passes through the pro-rata 75 percent loan guarantee to the air separation plant, with the equity component to be exclusively by Air Products. Under this 
approach, the SFC would bear the risk of 75 percent of the air separation plant through the loan guarantee. The balance of the risk for the air separation plant would be shared between the private sponsors of the project and Air Products, in a manner to be determined in the negotiation of termination charges. This approach allows the sponsors to separately finance the pro-rata part of equity that is represented by the equipment. The risk of project performance would continue to be borne by the equity sponsors.

\subsection{EQUITY FINANCING}

There are three possible sources of equity financing for the project: project sponsors, financial institutions and other potential passive investors.

Active project sponsors are the most likely source of equity in that their role in the project, including sales of hardware and services and strategic industry positioning, provide benefits to the project sponsors that are not available to purely financial investors.

Among the possible range of financial institutions, only certain life insurance companies and property and casualty companies have made investments of the type necessary for the Keystone Project. Large life insurance companies have been less active because certain reinsurance practices of the companies reduce their effective tax rate, lowering the value of $\operatorname{tax}$ benefits. At this time, the property and casualty companies do not have the available earnings to utilize tax benefits. However, the Tax Equity and Fiscal Responsibility Act of 1982 has altered the tax treatment of the reinsurance practices of life insurance companies, making tax benefits more valuable to these potential investors.

Financial institutions and other potential passive investors are likely to consider a project only when the general terms and conditions of financial assistance are known. This suggests that, unless the sponsors are willing to invest 100 percent of the equity, terms and conditions that are deemed attractive to passive investors must be negotiated in advance with the SFC and then shown to other investors. 
Pollution control financing might be available for a minor amount of the project's overall financing requirement. The criterion that would determine the amount of pollution control financing is the present value of the net cost of individual items of equipment that have the sole purpose of cleaning waste streams prior to discharge. Equipment used in intermediate process steps is not eligible. This present value is net of the sale of future by-products derived from the cleanup process, particularly sulfur in the case of the Keystone Project.

The normal way in which pollution control bonds are financed is for the local jurisdiction to issue the bond but with a guarantee of payment by the corporate sponsor. The issue might be collateralized by specific items of equipment.

The need for full recourse guarantees by sponsors makes pollution control financing similar in risk to equity contributions by sponsors. Such pollution control financing could be considered part of the sponsors' equity commitment and be part of the 25 percent equity needed. The SFC has not clearly indicated its view on such financing as an equity contribution. Additional problems of control over individual assets in the event of default might lead the SFC to discourage this type of financing if certain pieces of equipment are separately collateralized.

\subsection{DEBT FINANCING}

There is a ready market for the full faith and credit guaranteed debt that would be issued for the Keystone Project. The project could have separate construction and permanent financing, which is typical of projects with the debt maturity needed for keystone. Alternatively, the project could issue long-term debt at separate points during the construction period that would become permanent debt. 


\subsubsection{PROJECT FINANCING ALTERNATIVES}

Three alternatives are available for the short-term construction period. The first alternative would be a straight commercial bank loan, with the government guaranteeing the bank. Traditionally, this option has been more expensive than other alternatives, but with a government guarantee for a project of this size, commercial banks could possibly offer competitive rates. These rates could be tied to the equivalent maturity Treasury rates, rather than the traditional indices for commercial bank floating rate loans.

The second alternative involves the establishment of a project finance company. This structure is shown in Figure 2-3. The finance company issues commercial paper which, in turn, is backed by a commercial bank line of credit. The bank is necessary in this transaction because, in default, the government will not honor the guarantee immediately but will specify some period, typically 60 days, to make payment. The government guarantee would be to the commercial bank. The lines of credit would be exercised only in default or if there were a crisis in the commercial paper market such that commercial paper could not be sold.

The cost of 3-month AAA commercial paper in relationship to the U.S. Treasury Bill rate is shown in Figure 2-4. The spreads have varied widely between commercial paper and equivalent Treasury rates, as yields have changed over the past few years. Additional costs of this financing would be a $1 / 4$ to $3 / 8$ percent annual fee to the commercial bank and 10 basis points for the commercial paper dealer. Because of the maturity required for repayment of Keystone Project debt, either of these debt instruments would be replaced by permanent debt at the end of the construction period.

The third alternative financing structure for the construction debt would be to put in place initially the financial structure for permanent-or long-term debt. This is shown in Figure 2-5. Under this structure, the project itself sells short-term notes that directly bear the government guarantee. In this case, a trustee, typically a commercial bank, acts on behalf of the noteholders. To issue extremely short maturities at favorable rates, the trustee or a separate depository bank would need to provide liquidity to the 


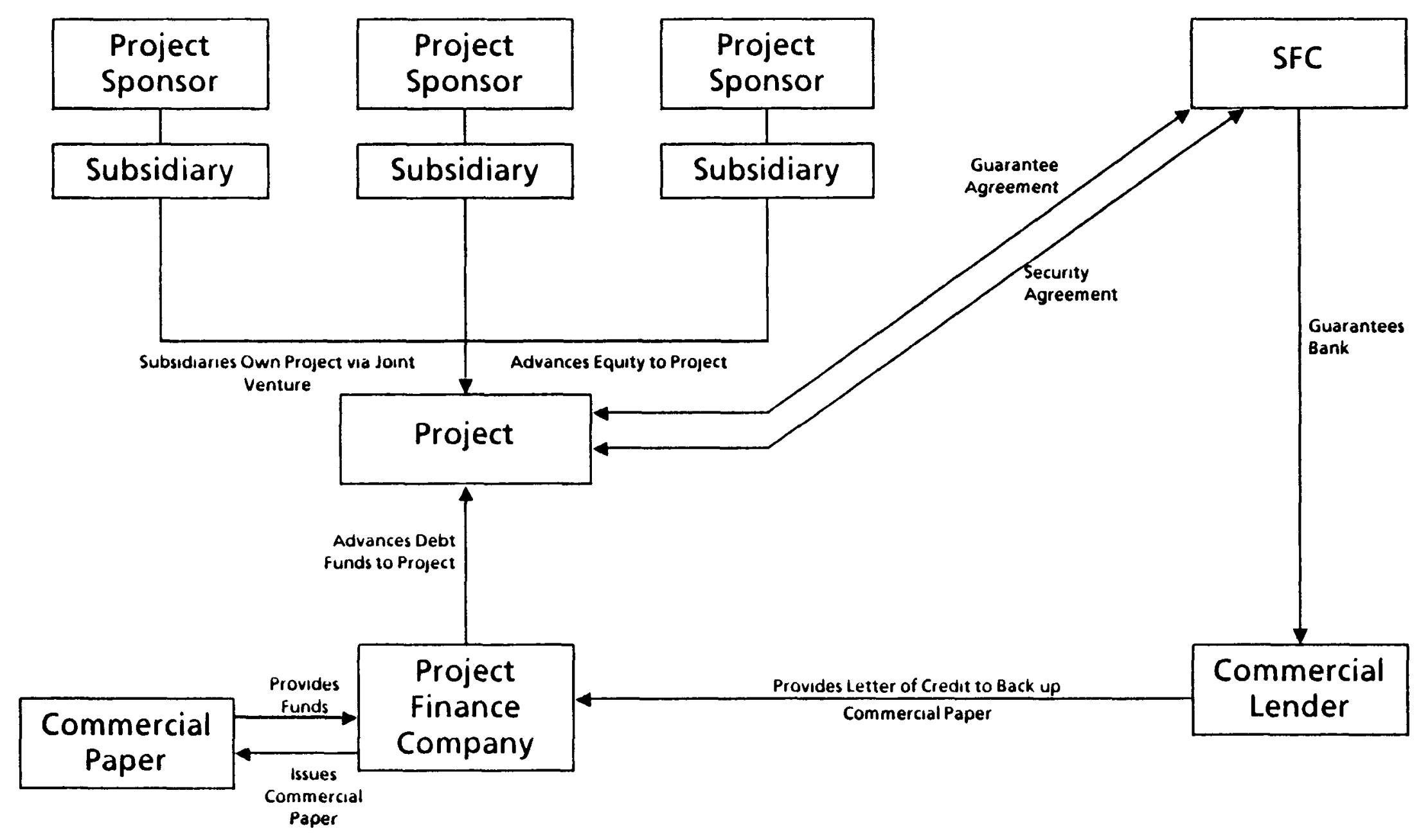

Figure 2-3 Construction Financing with Commercial Paper 


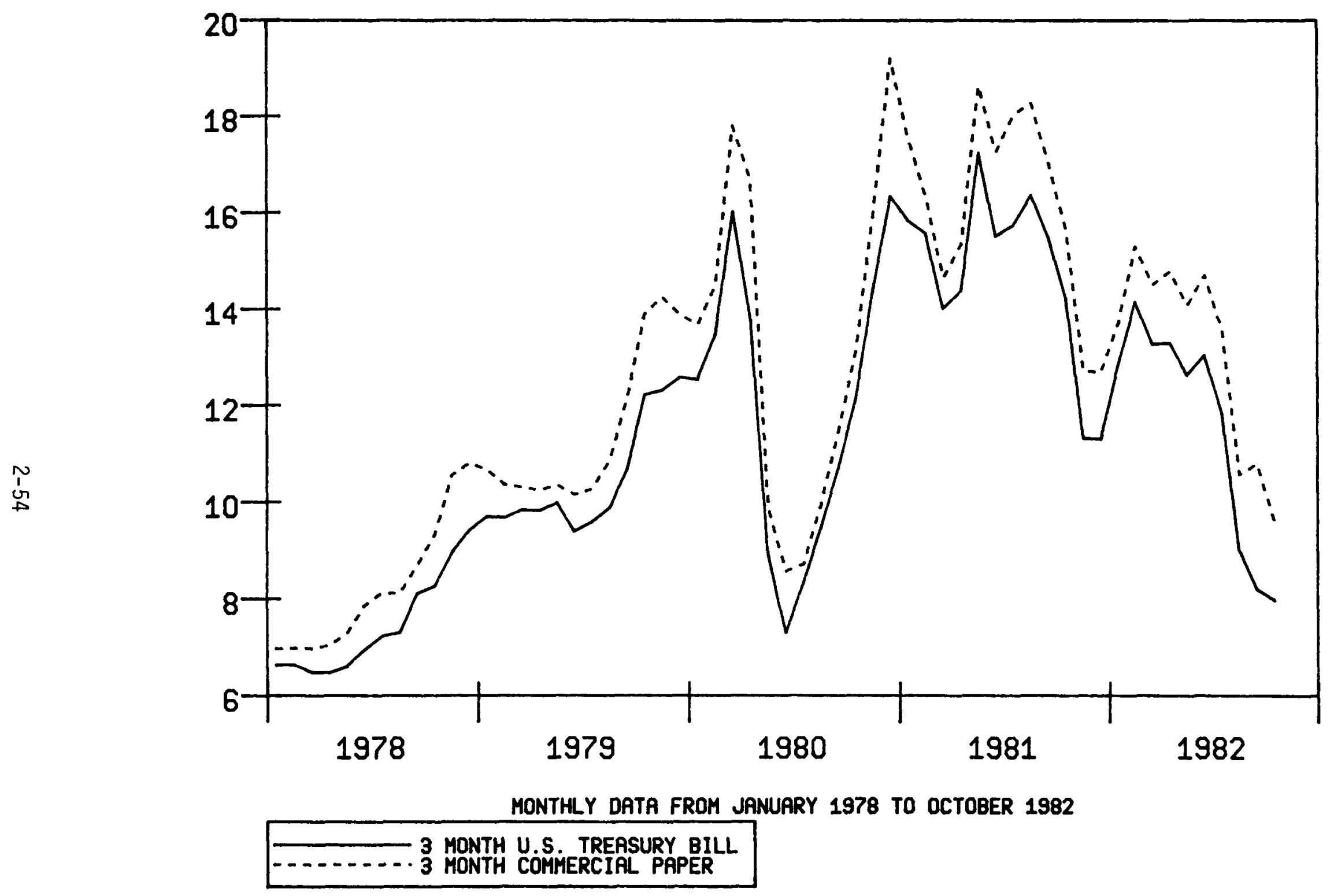

Figure 2-4 Comparison of Yield Between 3-Month U.S. Treasury Bill and 3-Month Commercial Paper 


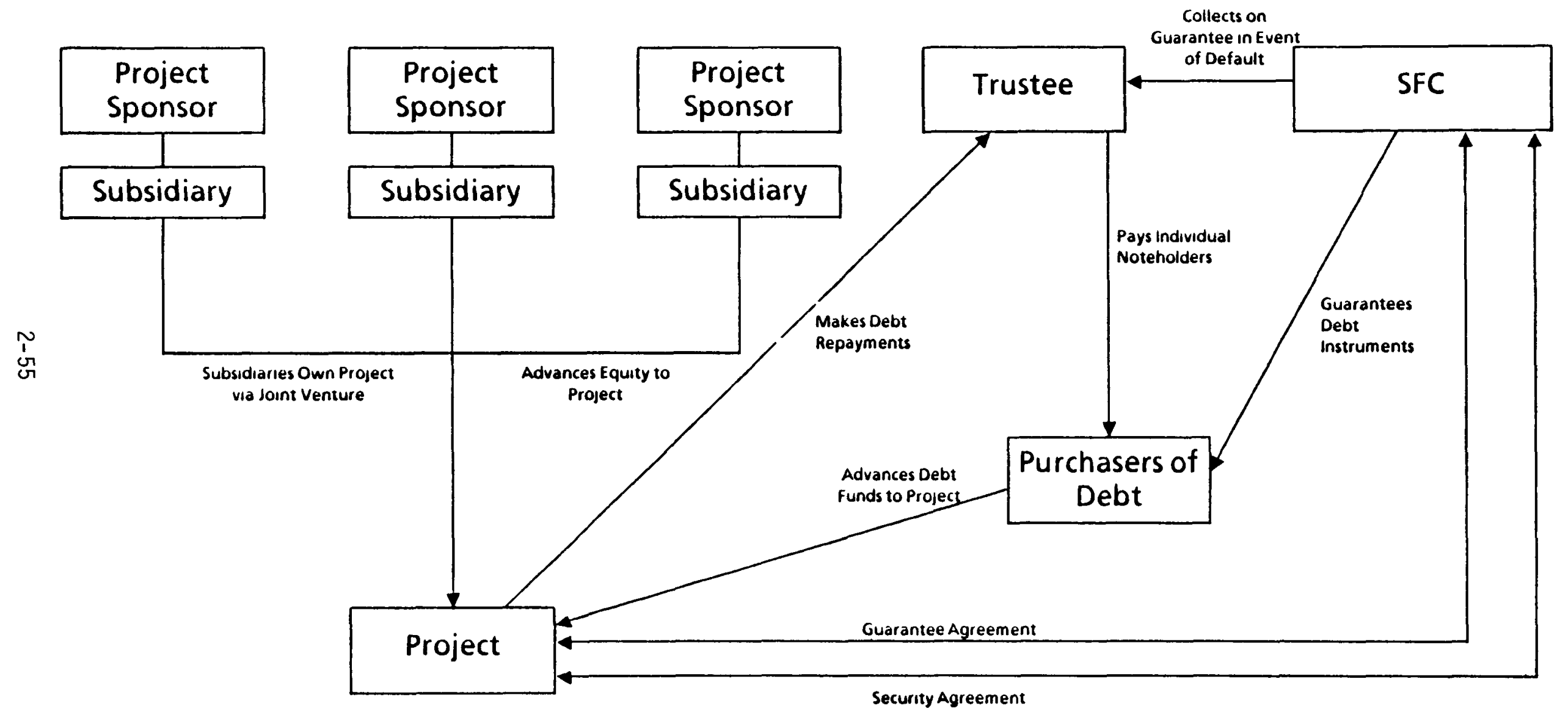

Figure 2-5 Project Financing with Direct Debt Instruments 
notes, as is done with commercial paper. The trustee collects interest and principal payments from the project sponsor, forwards payments to the noteholder and acts on the debtor's behalf in the event of bankruptcy. Depending on market conditions, under this structure the project could issue either long- or short-term debt.

Both long- and short-term SFC-guaranteed debt is likely to be priced similarly to existing government-guaranteed securities. The principal issues currently in the market are the Chrysler Corporation Notes, Title XI Ship Financing Notes and AID (Agency for International Development) Notes. The spread from comparable Treasury issues for initial SFC financing might be wider than existing guaranteed issues, if the project were to be among the first in the market with SFC debt. The wider spread would be necessary to compensate for the market's unfamiliarity with the SFC as an issuer of debt. However, given an initial and continuing effective distribution of information to the market, future issues of SFC-guaranteed debt should trade at narrower spreads with these spreads estimated to be approximately 65 to 100 bas is points.

Recent new issue Title XI notes should give some indication of likely new issue spreads. Recent larger Title XI issues are given in Table 2-11, showing amounts, maturities, average life, comparable issues and spreads. These spreads have varied historically from as few as 35 up to as many as 140 basis points. To the extent that the documentation is simplified and the issues are tradeable, significantly narrower spreads that Title XI can be realized.

A typical term sheet for government-guaranteed debt is shown in Table 2-12. Marketability of the debt would be enhanced by a pro-rate sinking fund, 10-year call protection, a good trustee and minimal documentation to traders. 
TABLE 2-11

1982 U.S. GOVERNMENT-GUARANTEED SHIP FINANCING BONDS AND NOTES

(ISSUES OVER \$25 MILLION)

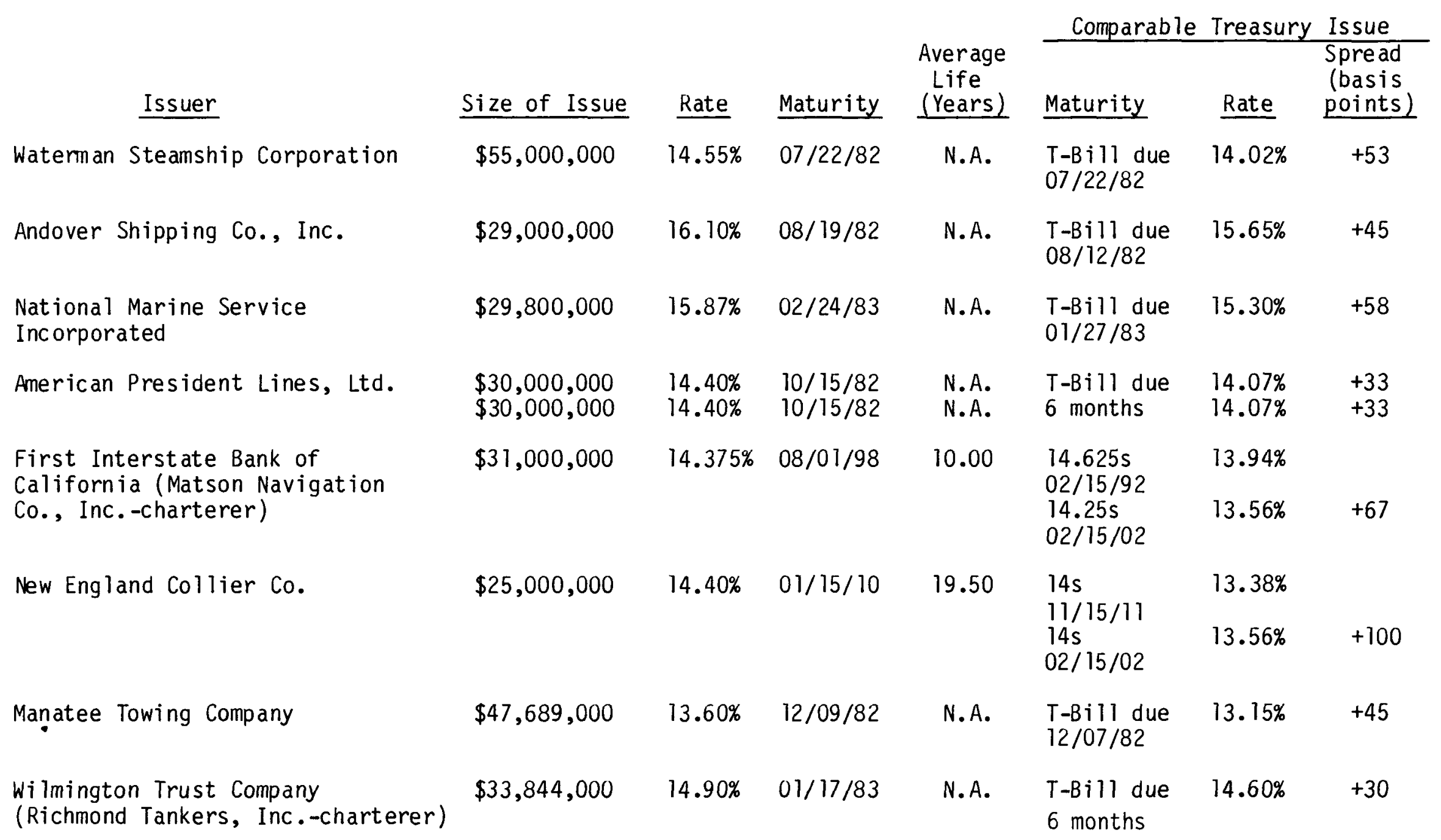


TABLE 2-11

(continued)

\section{Issuer}

Waterman Steamship Corporation

Beker Shipping Co., Inc.

Andover Shipping Co. Inc.

American President Lines, Ltd.

Apollo Co.
Size of Issue

$\$ 62.970,000$

$\$ 28,455,000$

$14.85 \%$

$08 / 12 / 07$

Rate

$13.35 \%$

$07 / 21 / 83$

(1)

$\$ 30,160,000$

$10.85 \% \quad 02 / 17 / 83$

$\$ 25,300,000$

$12.875 \%$

24.5 years

19.00

$\$ 30,000,000$
$12.82 \%$

$10 / 15 / 04$
N.A.
Comparable Treasury Issue

Spread

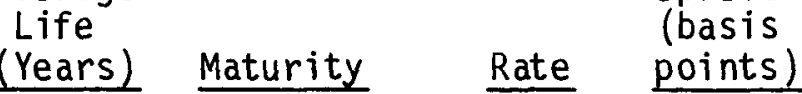

N.A. T-Bill due $12.60 \% \quad+75$

1 year

$13.50 \%+123$

$13.875 \mathrm{~s}$

$05 / 15 / 1$

$14.25 \mathrm{~s}$

$02 / 15 / 02$

$13.75 \%$

$T-B i 11$ due
6 months

$10.41 \%$

$+44$

$14.00 \mathrm{~s}$

$11 / 15 / 11$

$11.765 \%+110$

$11 / 5 / 8 \mathrm{~s}$

$02 / 15 / 02$

$11.72 \%$

$+110$ 
REPRESENTATIVE TERM SHEET

SYNTHETIC FUELS PROJECT WITH GOVERNMENT-GUARANTEED DEBT

AMOUNT

MATUR ITY

INTEREST RATE

REDEMPT ION

SINK ING FUNDS

EVENTS OF DEFAULT

U.S. GOVERNMENT

GUARANTOR

TRANSFER AND EXCHANGE

LIKELY IN VESTORS
$\$ 100-\$ 200$ million parcels. (Denominations of $\$ 1,000$ or $\$ 5,000$, or integral multiples thereof.)

20 to 25 years; level principal payments.

Semiannual payments; interest set at 65 to 100 bas is points above comparable Treasury maturity.

Non-callable for 10 years; redeemable at 100 percent of principal plus accrued interest to the date of redemption.

Pro Rate (if not, add 20 bas is points at issue).

Default is defined as:

(a) default in the payment of principal of or interest on the Note and the continuation of such default for 30 days, or

(b) failure by the project to observe various financial convenants and conditions.

The Synthetic Fuels Corporation (SFC) established under the Energy Security Act, enacted as Public Law 96-294 on June 30, 1980; appropriations for the SFC made available through P.L. 96-304.

The Notes would be transferable or exchangeable for Notes of other authorized denominations of like principal amounts without charge except for taxes or other governmental charges, if any, payable in connection therewith.

State and municipal pension funds, as they are required to invest part of the ir portfolios in either Treasury Notes of Government-Guaranteed securities. A private investor would be discouraged from investing in these securities as higher rates are obtainable in purchasing corporate bonds. 
0

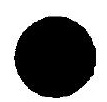




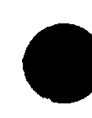

0 
SECTION 3.0

MARKET ANALYS IS

The market analys is that has been conducted for the Keystone Project is discussed in this section. Market research and individual contacts have identified specific applications and likely customers for both methanol and plant by-products. Information has been gathered on the state of the market and the status of various potential methanol uses.

\subsection{MARKETS FOR KEYSTONE METHANOL}

Beginning in 1988, the Keystone plant will be producing approximately 170 million gallons per year of anhydrous methanol. The results of the project's market research efforts indicate that this methanol will be sold in two main markets, the electric utility market and the motor fuel blend market. During the 1990's, some Keystone methanol may also be sold in the chemical markets, as well as for use as neat motor fuel, where a rapidly growing market is expected to emerge.

\subsubsection{MARKET SEGMENTS}

The potential market segments for Keystone methanol can be divided into four major categor ies:

(1) Low percentage gasoline blends

(2) Neat motor fuel

(3) Electric utility fuel

(4) Chemical uses

In addition, each major segment can be further subdivided into the subsegments shown in Table 3-1. This table also indicates the incentives that each market segment has to use methanol.

To assess methanol market potential in these segments, interviews were conducted with representatives from research organizations, governmental bodies, current and potential methanol users or producers and fuel and vehicle 
TABLE 3-1

METHANOL MARKET SEGMENTS

Segment

- Low percentage gasoline blends
Subsegments

- With cosolvent

- Without cosolvent

- Volume extender

- Octane enhancer

- Refineries

- Blender/Distributors

- Fleets
Incentives for Methanol Use

- Low-cost extender

- Provides octane

- Allows less severe reforming

- Neat fuel

- Diesel substitute

- Gasoline substitute

- Private use

- Railroads

- Fleets
- Security of supply

- Lower pollution

- Lower maintenance costs

- Improved performance

- Utility market

- Peaking turbines

- Combined cycle units

- Boilers

- Fuel cells
- Security of supply

- Supply flexibility

- Lower pollution

- Rescue capacity
- Chemical market

$$
\begin{array}{ll}
\text { - } & \text { Formaldehyde } \\
\text { - } & \text { Solvents } \\
\text { - } & \text { MTBE } \\
\text { - DMT }
\end{array}
$$

- Domestically available feeds tock 
producers. Extensive use was made of printed material and papers presented at trade and industry symposiums. Table 3-2 provides an overview of the range of contacts and a measure of their interest in using methanol.

\subsubsection{MARKET AREA}

The primary market area for the Keystone Project is within a 300-mile geographic radius of the plant, as shown on Figure 3-1. While the chemical and neat fuel market areas could cover the entire defined region, the utility and fuel blend market areas are likely to be restricted, as shown in the figure by existing market patterns and practices.

The high density of urban centers, population, industry and transportation infrastructure in this part of the United States establishes this primary market area. The region defines a realistic economic limit for transportation costs. The area can potentially take advantage of an existing oil products pipeline network that operates primarily in an east-west direction between Toledo, Ohio and the Philadelphia/Baltimore region with several northern spurs. These pipelines pass approximately 20 miles north of the Keystone Project site.

The Keystone market area can be further broken down, depending on the target market segment being investigated. For instance, petroleum products from New Jersey, Pennsylvania and Ohio refineries move east, west and north but not south. This means that Virginia and the District of Columbia can effectively be eliminated from the blend market area. In the case of the utility market, the primary area of interest is New York, New Jersey, Delaware and eastern Pennsylvania. Other portions of this market segment either have easy access to mine-mouth coal plants or have low oil usage. In both the neat fuel and chemical markets, the entire market area appears to be viable since effective transportation is available. 
TABLE 3-2

RESULTS OF METHANOL MARKET CONTACTS

Contacts

\begin{tabular}{|c|c|c|}
\hline & & $\begin{array}{l}\text { Potential } \\
\text { Methanol }\end{array}$ \\
\hline קט & $\begin{array}{l}\text { Level of Interest } \\
\text { in Methanol }\end{array}$ & $\begin{array}{c}\text { Users by } \\
1990\end{array}$ \\
\hline
\end{tabular}

Motor Vehicle Producers

Ford

General Motors

Future Fuels of America

Others

$\begin{array}{lll}x & x & x \\ x & x & x \\ x & x & x\end{array}$

$\begin{array}{ll}x & x \\ x & x \\ x & x \\ x & \end{array}$

Fuel Producers

Sun Company

ARCO Petroleum

$x \quad x \quad x$
$x \quad x \quad x$

$x$

$x$

Ash 1 and $0 i 1$

Union $0 i 1$

$x \quad x \quad x \quad x$

$x$

$x$

others

$x$

$x$

$x$

$x$

$x$

Utility Companies

Commonwealth Edison

Consolidated Edison

$x$

$x$

$x$

$x$

$x$

$x$ 
TABLE 3-2

(continued)

Contacts

\begin{tabular}{|c|c|c|}
\hline & & $\begin{array}{l}\text { Potential } \\
\text { Methanol }\end{array}$ \\
\hline ea of Interest & $\begin{array}{c}\text { Level of Interest } \\
\text { in Methanol }\end{array}$ & $\begin{array}{l}\text { Users by } \\
1990\end{array}$ \\
\hline
\end{tabular}

Duquesne Power and Light

Delmarva Power and Light

At 1 antic City Electric

others

$\begin{array}{llll}x & x & x & \\ x & & x & x \\ x & x^{x} & & x \\ & x & \end{array}$

Fleet Operators

$\begin{array}{llll}\text { Major Municipal Fleets } & X & X & X \\ \text { Major Private Fleets } & X & X & X\end{array}$

Research Groups

Southwest Research Institute

$\begin{array}{ll}x \times x & x \\ x & x \\ x & x\end{array}$

Methanol Users

\begin{tabular}{|c|c|c|}
\hline California Energy Commission & $x \times x$ & $x$ \\
\hline County of Los Angeles & $x$ & $x$ \\
\hline Bank of America & $x \quad x$ & $x$ \\
\hline
\end{tabular}

$4075 E$ 


\section{\KEYSTONE PROJECT}

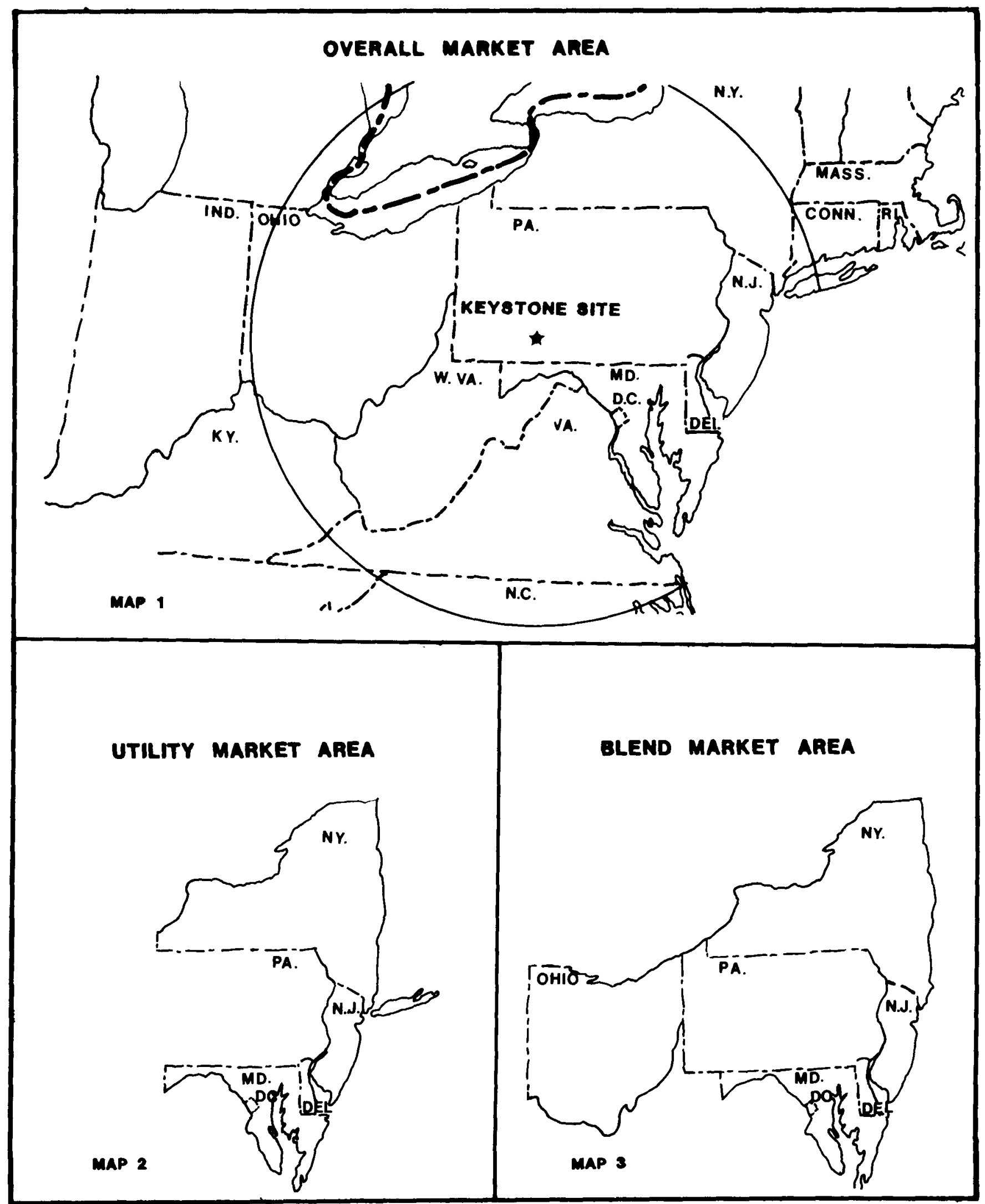

Figure 3-1 Geographical Location of the Keystone Product Market Areas 


\subsection{METHANOL MARKET PERSPECTIVES}

In assessing the potential for marketing Keystone methanol, it is appropriate to look at the national, and even the international, market, for several reasons. First, methanol can replace other liquid fuels. Second, most of the current domestic methanol capacity is located along the Gulf Coast with easy access by water to virtually all potential Keystone markets. Third, as methanol enters the fuel market, it will be competing with petroleum products which clearly function in an international arena. Finally, to the extent that imported methanol is an important competitive factor in the market, imports from the Middle East or Canada can reach the East coast as easily as they can reach the Gulf Coast.

The Keystone plant will not operate in a geographically isolated market. The plant location offers advantages or disadvantages to approaching different potential markets. The primary advantage is the plant's proximity to the northeastern population centers. The primary disadvantage is the lack of direct access to water transport and to current methanol users. To some extent, this disadvantage is mitigated by access to rail and pipeline transport.

Methanol is a basic chemical building block, and it has long been an internationally traded commodity. Current developments insure that this will continue to be the case, although significant shifts in world trading patterns will take place over the next five to ten years. Figure 3-2 summarizes the products that can be derived from methanol.

\subsubsection{INTERNATIONAL METHANOL PERSPECTIVE}

The current international methanol situation can be characterized by oversupply and depressed prices. The oversupply has been brought on by a number of factors. The world recession has reduced demand for end products, of which methanol is a major component. Several of the new methanol plants built to take advantage of inexpensive, remote natural gas sources have begun operation. These first plants are located in western Canada. Other existing 


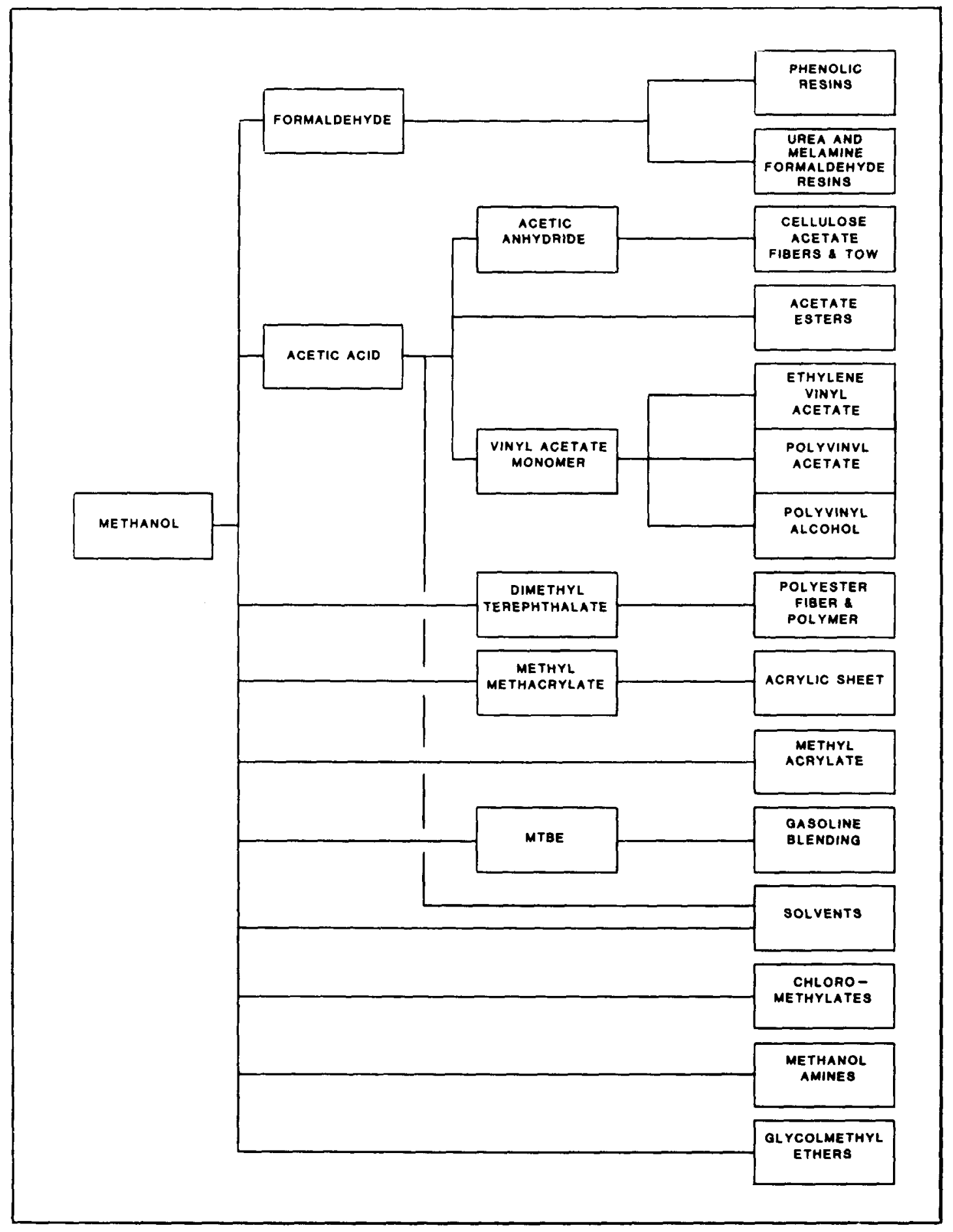

Figure 3-2 Products Derived from Methanol 
methanol plants have been modified to take advantage of the new, lower pressure methanol production technology that increases plant output by approximately 20 percent.

During this decade, more of these remote, natural gas-based methanol plants are expected to come on line in Canada, Saudi Arabia, Mexico and other locations. Due to the low cost of their natural gas feedstock, these plants will be able to produce methanol less expensively than existing plants in the United States or Western Europe. This is expected to lead to the decommissioning of some of these older plants.

With worldwide economic recovery, the demand for methanol for conventional chemical uses should return to normal. This market is expected to grow from 4 to 6 percent annually over the next ten years. The development of fuel uses and new chemical uses made possible by low prices for methanol could greatly increase this rate of growth. By 1985, the world methanol market should be characterized by brisk growth, as industrial development continues and new uses for methanol are commercialized. Canada and Saudi Arabia will serve as major exporters of methanol to Western Europe, Japan, and, to a lesser extent, the United States.

\subsubsection{DOMESTIC PERSPECTIVE}

In 1981, the United States exported 126 million gallons of methanol, which was 10 percent of domestic production that year. By 1983, domestic production capacity is scheduled to increase to 1.7 billion gallons. However, export markets are likely to be closed because of competition from lower cost Canadian methanol. Domestic producers are already facing stiff competition on the West Coast from Canadian producers.

The U.S. demand for methanol is also in a slump, due primarily to the recession in the housing market, where 35 percent of methanol has traditionally been absorbed as formaldehyde-based products (see Table 3-3). At the same time, many producers have modified their plants to use the new low pressure methanol synthesis process to gain up to 20 percent capacity. Two new methanol plants have been built: ARCO's 200-million gallon plant in 


\section{TABLE 3-3}

\section{U.S. CHEMICAL METHANOL CONSUMPTION BY END-PRODUCT}

End-Product

Formaldehyde

Acetic Acid

Solvent

Chloromethane

Metha-Methacrylate

Dimethyl ter aphthal ate

MTBE

Methyl amine

other

TOTAL
1980

$36.7 \%$

9.4

8.6

6.8

4.8

3.2

3.2

5.7

21.6

$100 \%$
1981

$34.1 \%$

10.8

7.5

6.2

4.4

1.8

11.5

5.0

18.7

$100 \%$

Source: PACE Engineer ing 
Channelview, Texas, and Getty's 100-million gallon plant at Delaware City, Delaware. As a result, methanol prices are being discounted 30 percent off list, and many producers appear to be operating at breakeven levels.

Offsetting this current depressed situation is the fact that an economic recovery and some development of the fuel methanol market will rapidly soak up excess supplies. SRI International estimates that demand for methanol for fuel use could increase total demand by 20 to 30 percent. Due to high domestic natural gas costs, no new plants are likely to be constructed beyond those coming on line in 1983.

Based on an analys is of existing information and interviews with methanol end users, the Keystone Project believes the United States will be in an import position for conventional chemical methanol uses by the end of the decade (see Table 3-4). The current overcapacity should be absorbed by 1985-87, and by 1990, the United States will be in a net import position if domestic plants operate at less than 100 percent of nameplate capacity. Historically, methanol plants have operated at 90 percent of capacity on a long-term bas is. Table 3-4 presents a projection of North American supply and demand through the year 2000. This table places U.S. supply at 1.78 billion gallons in 1990 with chemical demand at 1.88 billion gallons.

Therefore, development of any major new uses for methanol should create a strong demand for additional plant capacity, and coal-based methanol plants become logical candidates to fill any increased demand.

\subsubsection{PRICING PERSPECTIVE}

Domestic and international methanol prices are depressed due to oversupply. This situation is aggravated by the fact that methanol is a commodity product whose producers have a strong incentive to cut prices to maintain high operating rates at the ir plants.

The current domestic market is supplied primarily by natural gas-based plants. The only exceptions to this are DuPont's Deer Park Plant, which uses residual oil, and Getty's Delaware City Plant, which uses refinery

$4071 E$ 
TABLE 3-4

NORTH AMERICAN METHANOL SUPPLY AND DEMAND

(B ILL IONS OF ANNUAL GALLONS)

\begin{tabular}{|c|c|c|c|c|}
\hline & 1981 & $\underline{1985}$ & $\underline{1990}$ & $\underline{2000}$ \\
\hline U.S. Nameplate Capacity* & 1.48 & 1.98 & 1.98 & 1.98 \\
\hline Capacity at 90 percent Operating Rate & 1.33 & 1.78 & 1.78 & 1.78 \\
\hline Other North American Capacity & .21 & .72 & 1.02 & 2.42 \\
\hline Total North American Capacity & 1.69 & 2.70 & 3.00 & 4.4 \\
\hline U.S. Chemical Demand & 1.12 & 1.49 & 1.88 & 3.10 \\
\hline Other North American Demand & .11 & .28 & .32 & .6 \\
\hline MTBE Demand & .04 & .17 & .20 & .40 \\
\hline Total Demand & 1.27 & 1.94 & 2.40 & 4.1 \\
\hline
\end{tabular}

* From Conventional Sources, assumes no plant retirements.

Source: $\quad$ World Methanol '81

Note: $\quad$ This Table was developed from interviews with individual end users of methanol. 1981 represents a depressed base year. 
by-products. Domestic pricing will be tied to the rise of natural gas prices under the Natural Gas Pricing Act. These increases will be tempered by the effects of long-term contracts and the availability of old gas that will remain under controls. Figure 3-3 shows projected natural gas and methanol prices from several sources. The price forecasts used in this study are based on a consensus view of future natural gas prices and on interviews with major domestic methanol producers. The "U.S. Producers-Desired Price" line is an attempt to summarize all available information. The actual market price could approach the "PACE" line due to the effects of imports. Mid-term and long-term price projections indicate a price recovery when the current oversupply is absorbed.

Prices beyond 1983-84 will be characterized by a compromise between domestic producers, with high feedstock costs, and offshore producers (primarily Canada and Saudi Arabia), with low feedstock costs but higher capital, transportation and tariff costs. Figure 3-4 shows price projections for domestic and $C$ anadian producers. The market price for chemical methanol should fall in the band delineated by these two curves.

\subsection{MARKET POTENTIAL}

This section discusses the methanol market potential for each major market segment previously identified as a target for Keystone methanol.

\subsubsection{UTILITY FUEL MARKET}

\subsubsection{Potential Uses}

Methanol can be used by electric utilities as a fuel for the generation of electricity in the following ways:

(1) Direct combustion in boilers

(2) Fuel for simple-cycle turbines

(3) Fuel for combined cycle units

(4) Reformer fuel to supply hydrogen to fuel cells 


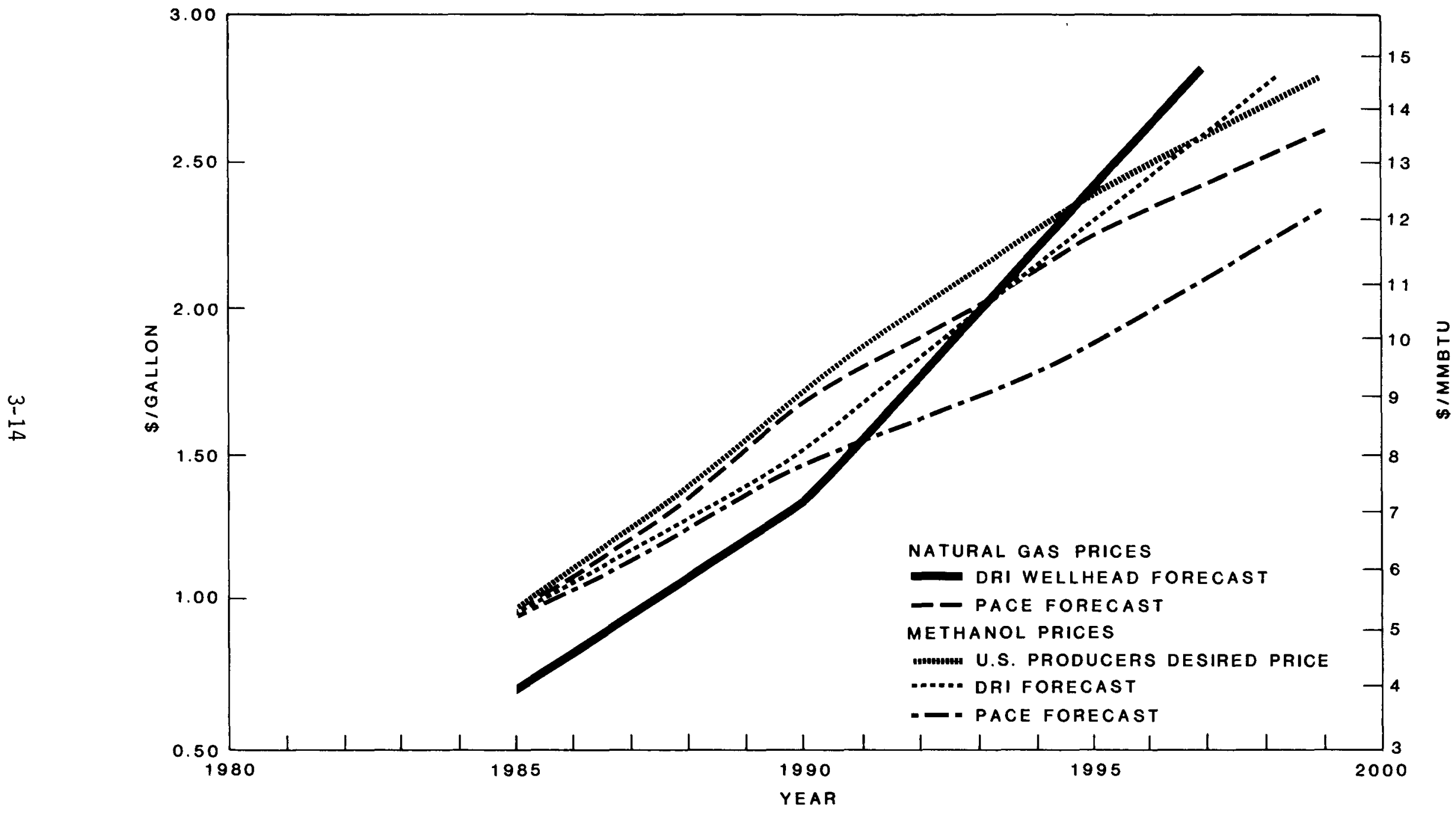

Figure 3-3 Projected Natural Gas and Methanol Prices from Several Sources 


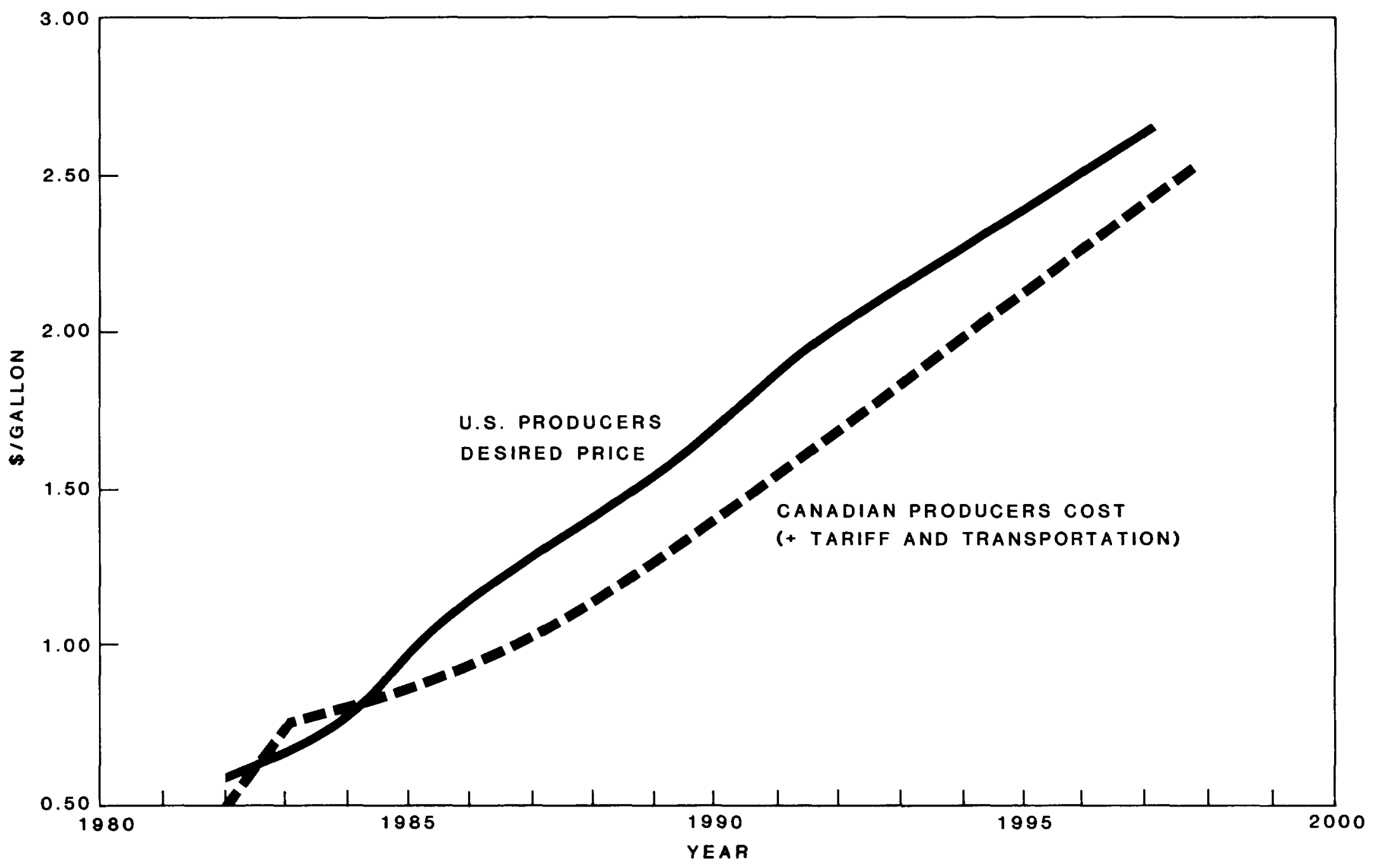

Figure 3-4 Price Projections for Domestic and Canadian Producers 
In each of these uses, methanol can displace oil or natural gas. The project's market research has indicated that the most attractive uses in the near term will be as a boiler or combined cycle fuel. Fuel cell use is a prospect for the future. Methanol offers utilities a clean-burning fuel with excellent environmental characteristics.

The utility market will emerge only if methanol is promoted by producers as a solution to a specific utility problem. A utility must have a pollution problem or the need to site new generation close to an existing load center.

\subsubsection{Long-term Contracts}

The utility fuel market is the only potential methanol market that offers long-term take or pay contracts. This makes it an attractive market despite the low price available for methanol on a competitive bas is.

Utilities typically buy fuel under 10-year or longer contracts. Potential customers have indicated a willingness to purchase methanol if it were priced competitively under long-term take or pay contracts containing built-in escalators.

\subsubsection{Technical Basis}

The feasibility and desirability of using methanol as a fuel for electric utility use has been verified by pilot tests conducted by Westinghouse, Southern California Edison, Pacific Gas and Electric, The Electric Power Research Institute and others. As a clean-burning fuel, methanol has major environmental advantages. The main differences between an oil-fired unit and a methanol-fired unit 1 ie in pumps, valving and tankage to accommodate the higher volumes of methanol needed and the elimination of any elastomers not compatible with methanol. The burning of methanol produces no sulfur or particulate emissions and minimal nitrogen oxides. As a turbine fuel, methanol also offers performance advantages in the form of lower maintenance requirements and lower heat rates due to higher mass flows. 


\subsubsection{Utility Incentives}

Methanol offers utilities the following advantages over other available fuels:

(1) Secure domestic fuel supply

(2) Extremely low pollution

(3) Low capital costs

(4) No solid waste products from combustion

These advantages allow utilities to $\mathrm{plan}$ economical new generation facilities close to load centers or to rescue older facilities that will otherwise have to be retired. Price supports from the SFC would close the gap between the Keystone-required price and the price of competing fuels. With lower capital costs and a capacity factor of 50 to 60 percent, the bus bar cost of power would be the same for the combined cycle plant as for the grassroots coal plant.

\subsubsection{Combined Cycle P lants}

In general, new combined cycle units offer the most attractive market for methanol. In comparison to a grassroots coal unit, a combined cycle unit costs one-third as much and can be built in a shorter time, further reducing interest during construction and escalation. For example, one utility projected a need for 300 megawatts of new capacity in 1992 and planned to build a grassroots coal-burning facility. The Keystone Project was able to show that a 300-MW combined cycle unit could be built in less time and for one-third the capital. This combined cycle unit would be built to accommodate three fuels: methanol, distillate and natural gas. The only fuel reliably available on a long-term contract would be Keystone methanol.

By fueling these units with methanol, pollution problems are minimized, which allows new units to be located close to load centers. In addition, concerns about supply interruptions are minimized. During the early years of operating a combined cycle plant fueled by Keystone methanol, a price support would be required to make the methanol competitive with distillate oil or contract natural gas. Discussions with utilities indicate that a price premium on the 
order of 10 percent over these alternative fuels could be justified. On this basis, a reasonable subsidy could make a combined cycle plant operating at 50 percent capacity competitive with a new coal plant operating at a similar load factor.

Methanol can be used to rescue older plants that will otherwise have to be retired. Several northeast utilities are faced with the retirement of units currently on oil due to pollution constraints. By firing such units with methanol, pollutant levels can be maintained while the facility is kept in service as an intermediate-load generating facility.

\subsubsection{Fuel Cells}

Fuel cells are expected to be a rew source of electricity generation in the 1990 's and beyond in both central generation and cogeneration applications. Methanol is an ideal fuel for fuel cells, since it is easily reformed to produce hydrogen. Significant capital savings and operating efficiency increases can be realized. The fuel cell users group, as well as equipment manufacturers and the DOE, are working to commercialize these units. Westinghouse and Niagara Mohawk are leaders in this effort. They expect fuel cells to be commercially proven by the late eighties and believe that methanol will be the fuel of choice for these units if it is available. The use of methanol increases the efficiency of a fuel cell by 2 to 4 percent and allows for decreased original capital costs. Total methanol use in fuel cells could be 150 to 200 million gallons per year by 1995 .

The viability of fuel cells and of methanol as a fuel for these units is being borne out by Department of Defense (DOD) tests. The DOD plans to deploy small fuel cells as field generation units. Tests are currently underway to verify the choice of methanol as fuel for these units. While DOD is not going to be a major user of methanol, its testing is an encouragement to industry contentions that methanol is an excellent power generation fuel. 


\subsubsection{Market Potential}

Some potential utility customers for Keystone methanol have been identified in Table 3-2. The primary utility market area for Keystone is shown on Map 2 of Figure 3-1. The project is continuing conversations with selected utilities to obtain letters of interest for the purchase of Keystone methanol.

The utilities in the northeast, especially those in the New Jersey, Delaware and New York portions of the Keystone marketing area, are prime candidates for methanol use. These utilities tend to be heavily oil-dependent and are currently predicting low load growth due to stagnant economic activity. If their growth exceeds predictions, they will be needing additional capacity with short lead times for construction. This capacity will be more valuable if it can be placed near load centers.

Methanol will not replace all oil and gas consumed by the electric utility industry in the keystone market area. It may, however, be used in one or two specific applications, and several potential applications have been identified. Any one of these applications could consume from 40 percent to well over 100 percent of Keystone's output. For example, a single 300-MW combined cycle unit operated at a 50 percent capacity factor will consume all of the project's first module output.

The objective for Keystone is to develop an application for methanol in the utility fuel market that justifies a premium price for methanol. Ideally, this application will consume 50 to 75 percent of the keystone output.

\subsubsection{Competitive Prices}

Projected prices for competing fuels are listed in Table 3-5.

\subsubsection{Petroleum Displacement}

Methanol will replace petroleum fuels on a Btu basis adjusted for any operating efficiencies gained through the use of methanol. In the case of a combustion turbine, the unit operates 5 percent more efficiently on methanol. 
TABLE 3-5

COMPETITIVE FUEL PRICES

FUEL

Crude $0 i 1, \$ / b b$ l delivered

$\$ / M M$ Btu

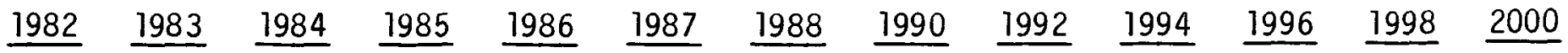

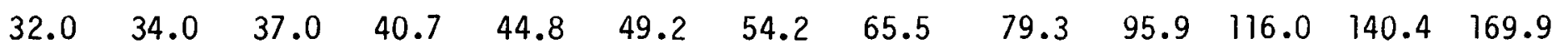

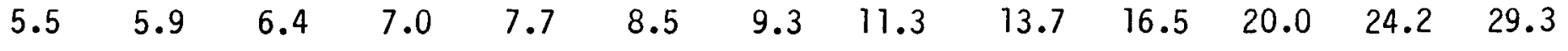

$0.3 \%$ S \#6 Fuel $0 i 1$, $\$ / b b 1$ East Coast

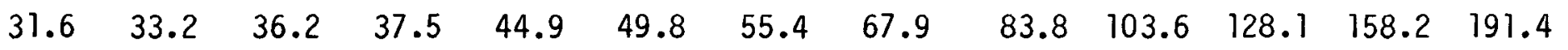

$\$ / M M$ Btu

$5.2 \quad 5.4 \quad 5.9$

$0.2 \%$ S \#2 Fuel 0i1, $\$ / b b l$ East Coast

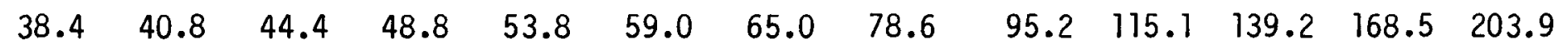
$\$ /$ MM Btu

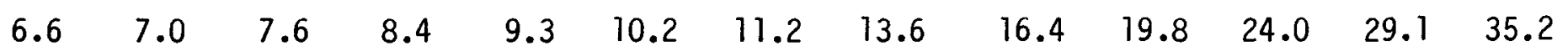

Unleaded Regular Gasoline, \$/bbl

$\$ /$ gal

$\$ / M M$ Btu

$\begin{array}{rrrrrrrrrrrrr}42.0 & 45.0 & 49.0 & 57.0 & 62.7 & 68.9 & 75.9 & 91.7 & 111.0 & 134.3 & 162.4 & 196.6 & 237.9 \\ 1.00 & 1.07 & 1.17 & 1.36 & 1.49 & 1.64 & 1.81 & 2.18 & 2.64 & 3.20 & 3.87 & 4.68 & 5.66 \\ 8.0 & 8.6 & 9.4 & 10.9 & 11.9 & 13.1 & 14.5 & 17.4 & 21.1 & 25.6 & 31.0 & 37.4 & 45.3\end{array}$

Nominal forecast for firm new contract gas to utilities, $\$$ MM Btu $\begin{array}{lllllllllllll}5.0 & 6.5 & 7.3 & 8.0 & 9.0 & 10.0 & 11.0 & 14.0 & 17.0 & 20.0 & 25.0 & 31.0 & 36.0\end{array}$ 
A Btu from methanol replaces 1.05 Btus from distillate, or one gallon of methanol will replace one-half gallon of distillate. The entire Keystone Project output would displace approximately 84 million gallons per year of distillate if used in utility applications.

\subsubsection{MOTOR FUEL BLEND MARKET}

\subsubsection{Market Development}

A new market is developing for methanol use in gasoline at low percentage blends. The magnitude and permanence of this market will be subject to interaction of the following factors:

(1) Price and availability of crude oil

(2) Price and availability of methanol

(3) Availability of alternative octane enhancers

(4) Cost of incremental reforming

(5) Demand for higher octane gasolines

(6) Government actions on motor fuel taxes

(7) Government regulations on lead, vapor pressure and oxygenates in gasoline

(8) Availability of suitable cosolvents (see below)

There is concern, especially among auto manufacturers, that low percentage methanol/gasoline blends will either damage existing vehicles or cause problems with car operation. These fears appear to be unfounded if a cosolvent is used and good housekeeping practices are enforced throughout the distribution chain. Atlantic Richfield Company (ARCO) is following such practices in their introduction of 0xinol-enhanced unleaded gasoline in the Northeast. (0xinol is a blend of 50 percent tertiary butyl alcohol and 50 percent methanol.)

The cosolvent is included to control phase separation and minimize corrosion. A straight methanol/gasoline blend can only be maintained if the water content is less than $200 \mathrm{ppm}$. The current cosolvent of choice is gasoline-grade tertiary butyl alcohol (TBA). There is only one supplier of TBA, ARCO 
Chemical Company, whose capacity is limited to approximately 400 million gallons per year. Chemical Economics Handbook estimates that only 200 million gallons per year are available for gasoline use. It is likely that other cosolvents will be developed and that the allowable ratio of methanol to cosolvent will be increased, thus lessening the chance that cosolvent supply will constrain the size of this market.

In addition to the ARCO program, other proposals for the addition of methanol to the gasoline pool have been advanced. Some involve higher percentages of methanol (10 to 40 percent) and proprietary additives to control corrosion and phase separation, and another involves adding up to 3 percent methanol to unleaded gasoline without a cosolvent. Such proposals are running into much resistance from fuel distribution, automotive and governmental bodies.

\subsubsection{Octane Demand}

Unleaded gasoline is expected to capture 88 percent of the total gasoline market by 1990 (see Table 3-6), with 25 to 35 percent of this gasoline being sold as premium unleaded. The shift toward higher octane unleaded products will create a demand for octane that will be partially met by methanol. Low percentage methanol blends will be used by particular refineries or companies that do not have access to other, less expensive substitutes.

In a case where there is a need for octane, methanol trails only methyl tertiary butyl ether (MTBE) and incremental reforming as the least expensive octane enhancer. The value of any octane enhancer to an individual refinery depends on many factors including the type of crude received, utilization rate, and the market price of butane.

\subsubsection{MTBE}

Methyl tertiary butyl ether, commonly known as MTBE, is an accepted octane enhancer that contains one-third methanol. Production of MTBE is limited by the availability of isobutene, the other two-thirds of the blend. Available isobutene supply is expected to be sufficient to consume approximately 200 million gallons of methanol in 1990. MTBE production facilities are located 
TABLE 3-6

U.S. GASOLINE USE BY GRADE

(MILL IONS OF BARRELS PER DAY)

\begin{tabular}{|c|c|c|c|c|c|}
\hline & $\begin{array}{l}\text { Un leaded } \\
\text { Premium }\end{array}$ & $\begin{array}{l}\text { Unleaded } \\
\text { Regular }\end{array}$ & $\begin{array}{l}\text { Leaded } \\
\text { Regul ar }\end{array}$ & $\begin{array}{l}\text { Leaded } \\
\text { Premium }\end{array}$ & Total \\
\hline 1980 & 391 & 2454 & 3475 & 312 & 6632 \\
\hline 1985 & $1118-1613$ & $2684-3179$ & 1530 & 59 & 5886 \\
\hline 1990 & $1517-2088$ & $2989-3566$ & 634 & 58 & 5769 \\
\hline 2000 & $2115-2814$ & $3307-4000$ & -.. & 62 & 6183 \\
\hline
\end{tabular}

Source: PACE Engineering 
along the Gulf coast where Keystone methanol would be at a transportation cost disadvantage. Thus, MTBE production is not a realistic market for Keystone methanol.

\subsubsection{Methanol Market Value}

Air Products and Chemicals conducted an extensive study for the project on the value of methanol as an octane enhancer. The methanol price from this and other studies cluster in the $r$ ange of 55 to 85 percent of the unleaded gasoline price, with variations for individual refiners based on numerous factors, such as the following: (1) The price and availability of cosolvent; (2) the availability of crude; (3) the mix of gasoline grades produced; (4) the price of butane; (5) the availability of other octane enhancers; and (6) the availability of incremental reforming capacity.

Methanol increases in value at a particular refinery when the need for purchased octane increases and the market price of butane goes up. For a refiner such as Ashland at Catlettsburg, with the ability to produce many octane ingredients and having adequate crude supplies, methanol has a relatively low value.

Three primary factors tend to hold down the value of methanol in gasoline blends:

(1) The need to backout butane to meet vapor pressure regulations.

(2) The need to average relatively high-priced cosolvent into the total price of a methanol-based octane enhancer.

(3) The need to overcome initial resistance of refiners and marketers to the use of a new product.

In time, the impact of the latter two factors should lessen, increasing methanol value in the marketplace. DuPont and other methanol producers are attempting to reduce the ratio of required cosolvent or eliminate the cosolvent altogether. Resistance by refiners and marketers will decrease as experience is gained with methanol blends. 
The subject of projected methanol price when it is used as an octane enhancer in the blend market is discussed in Section 3.5.2.2.

\subsubsection{Market Size}

The market for low percentage blend fuels is expected to consume 200 to 400 million gallons of methanol in 1985 and to continue to increase in size from that point. This represents a 6 to 9 percent penetration of the unleaded gasoline market at a 5 percent blend level. As refiners gain experience with methanol-based octane enhancers, the need for cosolvents will decrease.

Refineries in the Keystone area (see Table 3-7) comprise 15 to 20 percent of national refining capacity. ARCO and Sun, and in all probability Getty, will be the first refiners to use methanol as an octane enhancer. Northeastern refiners have a greater incentive to use methanol due to the higher level of uncertainty about their crude supply. If this incentive continues, the potential blend market available to Keystone will be greater than the percentage of national refining capacity in the defined market area.

\subsubsection{Petroleum Displacement}

On the simplest basis, methanol used in gasoline blends will replace gasoline on a Btu basis, so the entire Keystone output would replace 87 million gallons of gasoline per year. This figure would be higher to the extent that there are energy losses in the production of either the gasoline or the high octane aromatics that methanol would replace.

\subsubsection{NEAT METHANOL FUEL}

\subsubsection{Technical Basis}

Methanol can be used as a neat fuel to replace either gasoline or diesel fuel. In either application, methanol is less desirable because it has a significantly lower heat content than the fuel it is replacing. In the case of gasoline, methanol contains approximately one-half the energy, or Btus, of gasoline. In the case of diesel fuel, it has approximately one-third. This 
TABLE 3-7

MA JOR REF INERS IN KEYSTONE MARKET AREA

Delaware

Getty Refining and Marketing Co.

Kentucky

Ashland Petroleum Co.

Maryl and

Amoco Oil Co.

Chevron U.S.A. Inc.

New Jersey

Chevron U.S.A. Inc.

Exxon $\mathrm{Co}$.

Mobil 0 il Corp.

Seaview Petroleum Inc.

Texaco, Inc.

New York

Ashland Petroleum Corp.

Cibro Petroleum Products Inc.

Ohio

AshTand Petroleum Co.

Gulf 0 il Co.

Standard 0 il Co. of Ohio

Standard $\mathrm{Oil} \mathrm{Co}$. of Ohio

Sun Co.

Pennsylvania

AtTantic Richfield Co.

B.P. Oil Corp.

Gulf Oil Co.

Pennzoil Co.

Sun $\mathrm{Co}$.

United Refining

West Virginia

Quaker State $0 i 1$ Refining Corp.

Virginia

Amoco Oi] Co.

TOTAL CAPACITY IN MARKET AREA
Delaware City

$150,000 \mathrm{~b} / \mathrm{sd}$

Catlettsburg

Baltimore

Baltimore

Perth Amboy

Linden

Paulsboro

West Deptford

Westville

North Tonawanda

Albany

Canton

Cincinnat $i$

Lima

Toledo

Toledo

Philadelphia

Marcus Hook

Philadelphia

Rouseville

Marcus Hook

Warren

Newell

Yorktown

$2,574,000 \mathrm{~b} / \mathrm{sd}$
55,000

66,00

45,000

68,000

45,000

177,000

126,000

130,000

130,000

177,000

180,000

15,600

180,000

43,000

12,000

b/sd $=$ barrels per stream day 
means that a car or truck would travel one-half to one-third the distance on a gallon of methanol than it would on a gallon of gasoline or diesel fuel. However, efficiency gains possible in a methanol engine mean that a vehicle can travel farther on a Btu of methanol than on a Btu of gasoline. This means that the consumer can achieve the same fuel economy or miles per dollar of fuel when the price relationship between gasoline and methanol is less than $2: 1$.

\subsubsection{Nature of Market}

The neat motor fuel markets accessible to Keystone methanol in the next ten years is the automobile and light truck fleet markets. Distribution and conversion problems will preclude early use of methanol by the general public. Medium and heavy duty fleet trucks are increasingly diesel-powered. Although it is technically feasible to replace diesel fuel with methanol with significant pollution benefits, this is not likely to happen for economic reasons. There is an equal or greater price differential between diesel fuel and methanol than between gasoline and methanol. This is aggravated by the fact that a diesel engine is more efficient than a gasoline, Otto Cycle engine. While a methanol engine will be more efficient than a gasoline engine, and will therefore partially compensate for the price differential between the two fuels, the same thing will not be true of a methanol-fueled diesel cycle engine. The full fuel price differential will remain. Also, the retrofit costs or premium production cost of the methanol-fueled engine will be higher. Finally, a large percentage of medium-and heavy-duty trucks operate in intercity travel, which highlights the problems of distribution.

Neither rail travel nor intracity buses are attractive for the neat fuel market. Rail travel has no incentive to change fuel other than price, and they would require a methanol price that is discounted from distillate. The intracity bus market is attractive for methanol because of its clean combustion characteristics, but the average turnover for city bus fleets is 15 years or longer. Market penetration would effectively be impossible. 
Methanol fueling of automobiles and light trucks presents no serious technological difficulties. The few minor problems that do exist, such as upper cylinder wear and cold start, are being rapidly solved by work conducted in California and other places. The primary emphas is of the work being done today is improving the distribution system and the efficiency of the methanol-fueled engine.

\subsubsection{Market Development Timing}

Without significant economic incentives, the introduction of neat methanol vehicles is likely to be slow. To gain perspective on this, it is instructive to look at the penetration of diesel-and LPG-fueled cars and light trucks. Especially in the case of diesel, there has been an economic incentive for years to use diesels. Yet it was not until 1978 that diesel cars became widely accepted. A similar pattern of market development has been followed for LPG-powered fleet vehicles. The neat fuel fleet market will develop, but it will develop slowly. While it is realistic to expect Keystone to be servicing this market by the mid-nineties, this market cannot be used to support the early years of plant operation.

\subsubsection{Market Size}

The total number of fleet cars and light trucks in the keystone market area is approximately 1.3 million. This represents a potential methanol market of 200 million gallons of methanol per year at 20 percent market penetration $(15,000$ miles per year per vehicle at $18 \mathrm{mpg}$ ). Such a market penetration may be achievable only after many years of market development. The dimensions of the fleet market in the Keystone market area are shown in Tables 3-8 and 3-9.

A scenario for the maximum feasible methanol-fueled vehicle introduction under "business as usual" conditions was received in talks with Ford and General Motors. The precursors for this scenario would be significant consumer demand for methanol-powered vehicles and a sufficient and reliable supply of fuel methanol. This scenario is outlined in Tables $3-10$ and 3-11. While the scenario is optimistic, and in reality will probably be considerably 
TABLE 3-8

KEYSTONE MARKET AREA FLEET CENSUS DATA

\begin{tabular}{|c|c|c|c|c|c|c|c|c|}
\hline State & $\begin{array}{l}\text { Total } \\
\text { Fleets } \\
\end{array}$ & $\begin{array}{c}\text { Bus/Taxi } \\
\text { Fleets } \\
\end{array}$ & $\begin{array}{c}\text { Total Str. } \\
\text { Trucks } \\
\end{array}$ & $\begin{array}{l}\text { Light* } \\
\text { Trucks } \\
\end{array}$ & Cars & Buses & Tractors & $\begin{array}{l}\text { Fleets w/ } \\
\text { Shop Fac. }\end{array}$ \\
\hline$D E$ & 264 & 11 & 11630 & 4536 & 6318 & 2601 & 9350 & 198 \\
\hline$D C$ & 171 & 9 & 262332 & 102309 & 28608 & 13859 & 10139 & 123 \\
\hline MD & 1021 & 29 & 64101 & 24999 & 32276 & 10469 & 17395 & 766 \\
\hline $\mathrm{NJ}$ & 2461 & 138 & 253673 & 98932 & 119461 & 1171 & 64970 & 1816 \\
\hline NY & 3982 & 166 & 302110 & 117823 & 332240 & 62310 & 57694 & 3180 \\
\hline $\mathrm{OH}$ & 3696 & 49 & 130119 & 50746 & 101714 & 28802 & 79129 & 2721 \\
\hline$P A$ & 4112 & 137 & 189617 & 73951 & 116182 & 22820 & 79034 & 3154 \\
\hline VA & 1316 & 24 & 93200 & 36348 & 38560 & 22087 & 23179 & 989 \\
\hline WV & 547 & 11 & 26160 & 10202 & 9605 & 7670 & 4036 & 440 \\
\hline Total & 17570 & 574 & 1332942 & 519846 & 784904 & 181789 & 344926 & 13387 \\
\hline
\end{tabular}

* Estimate.

Source: "Census and Projections to 1990 of The Motor Fleet Market." Chiltons Commercial Car Journal Copy 1980, The Chilton Co., Radnor, Pa. 
TABLE 3-9

KEYSTONE MARKET AREA

METROPOLITAN AREAS IN TOP FIFTY FLEET CENSUS

\begin{tabular}{|c|c|c|c|}
\hline SMSA* & Rank & \# of Fleets & $\begin{array}{c}\text { \# of Vehicles } \\
\text { Operated } \\
\end{array}$ \\
\hline New York, NY-N J & 2 & 1,366 & 677,685 \\
\hline Washington, $D L-M D-V A$ & 3 & 528 & 555,311 \\
\hline Philadelphia, PA-NJ & 8 & 1,356 & 316,733 \\
\hline Newark, NJ & 9 & 637 & 309,740 \\
\hline Cleveland, $\mathrm{OH}$ & 13 & 564 & 149,532 \\
\hline Syracuse, NY & 15 & 261 & 130,945 \\
\hline Baltimore, MD & 17 & 538 & 116,265 \\
\hline Nassau-Suffolk, NY & 20 & 503 & 101,911 \\
\hline Pittsburgh, PA & 22 & 622 & 97,658 \\
\hline Columbus, $\mathrm{OH}$ & 23 & 363 & 96,293 \\
\hline New Brunswick, NJ & 27 & 237 & 77,901 \\
\hline Cincinnati, OH-KY-IN & 33 & 416 & 72,709 \\
\hline Akron, $\mathrm{OH}$ & 39 & 255 & 59,890 \\
\hline Harrisburg, $P A$ & 45 & 188 & 51,388 \\
\hline Buffalo, NY & 50 & 433 & 43,829 \\
\hline
\end{tabular}

Source: "Census and Projections to 1990 of The Motor Fleet Market." Chiltons Commercial Car Journal Copy 1980, The Chilton Co., Radnor, Pa.

* SMSA - Standard Metropolitan Statistical Area. 
TABLE $3-10$

FORD MOTOR COMPANY'S PLAN FOR INTRODUCING

NEAT-FUELED VEHICLES TO THE U.S. MARKET

Markets $\quad \begin{gathered}\text { Ford } \\ \text { Volume/Year Vehicles Fuel Supply }\end{gathered}$

PHASE I

Present Selected fleets 1,000 1.6L Escort Present surplus

PHASE II $\begin{array}{llll}\text { 1985-1987 } \begin{array}{l}\text { Commercial fleets, } \\ \text { nationwide }\end{array} & 10,000 \quad 2 \text { engines; } & \text { Off-shore gas/ } \\ 2 \text { carlines } & \text { present surplus }\end{array}$

PHASE II I

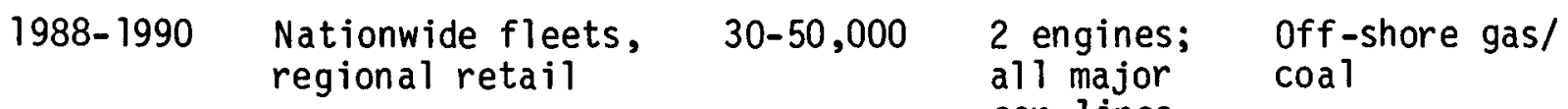

PHASE IV

Early 1990s Nationwide fleets 250-300,000 Open Coal

SOURCE: Statement of Dr. Roberta J. Nichols, Ford Motor Company, before the Biennial Report IV Synthetic Fuels Transportation Hearing, State of California Energy Commission, Sacramento, California, August 17, 1982. 
TABLE 3-11

SCENAR IO FOR DEVELOPMENT OF A NEAT MOTOR FUEL FLEET

\begin{tabular}{|c|c|c|c|c|c|c|}
\hline & $\frac{\text { Cars }}{\text { Ford }}$ & $\frac{\text { oduced }}{G M}$ & Other & Total & $\begin{array}{c}\text { Cumulative } \\
\text { Total }\end{array}$ & $\begin{array}{l}\text { Methanol } \\
\text { Consumed }\end{array}$ \\
\hline 1983 & 1,000 & -- & 150 & 1,150 & 1,150 & 958 \\
\hline 1984 & 1,000 & -- & 200 & 1,200 & 2,350 & 1,958 \\
\hline 1985 & 10,000 & 5,000 & 200 & 15,200 & 17,550 & 14,625 \\
\hline 1986 & 10,000 & 10,000 & 500 & 20,500 & 38,050 & 31,708 \\
\hline 1987 & 10,000 & 20,000 & 1,000 & 31,000 & 69,050 & 57,542 \\
\hline 1988 & 30,000 & 30,000 & 1,000 & 61,000 & 130,050 & 108,375 \\
\hline 1989 & 40,000 & 50,000 & 1,000 & 91,000 & 221,050 & 184,208 \\
\hline 1990 & 50,000 & 60,000 & 1,000 & 111,000 & 332,050 & 276,708 \\
\hline 1991 & 200,000 & 300,000 & 1,000 & 501,000 & 833,050 & 694,208 \\
\hline 1992 & 200,000 & 350,000 & 1,000 & 551,000 & $1,384,050$ & $1,153,375$ \\
\hline 1993 & 250,000 & 400,000 & 1,000 & 651,000 & $2,035,050$ & $1,695,875$ \\
\hline 1994 & 300,000 & $40 C, 000$ & 1,000 & 701,000 & $2,736,050$ & $2,280,042$ \\
\hline 1995 & 300,000 & 400,000 & 1,000 & 701,000 & $3,437,050$ & $2,864,208$ \\
\hline
\end{tabular}


stretched, it does present a picture of what could be easily accomplished by vehicle manufacturers. The difficulty is likely to be the supply and distribution of methanol.

\subsubsection{Petroleum Displacement}

The neat motor fuel market offers the largest potential for petroleum displacement with methanol. Methanol will replace gasoline on a Btu basis, but in an optimized engine, more miles per Btu will be obtained. Conservative estimates place the efficiency gains at 30 percent. An efficiency gain of this magnitude would allow each gallon of Keystone methanol to replace 0.72 gallons of gasoline. (This is based on methanol containing 55 percent of the Btu content of gasoline.) In total, the project could directly displace at least 147 million gallons of gasoline per year.

\subsubsection{CHEMICAL MARKET}

\subsubsection{Domestic Supply}

As has been discussed previously, the United States is likely to be in an import position for methanol for conventional chemical uses and MTBE production by 1990 (see Table 3-4). North American capacity is likely to stay ahead of chemical demand through the year 2000. For the chemical methanol market, Keystone, as a domestic producer, will enjoy transportation cost advantages and tariff protection from imported methanol. Keystone can expect to compete with foreign suppliers for the small northeastern chemical market in the decade of the nineties.

The majority of the existing methanol market is a captive market. The primary use area is in the forest products industry in the southeast and the Northwest. The only significant methanol use in the Keystone market areas is as a solvent. This use is not expected to grow significantly.

In attempting to compete with existing domestic chemical producers, Keystone would be at a transportation cost disadvantage. On that basis, the domestic chemical market is not a reasonable target market for keystone. 
In 1990, as the United States moves into an import position for chemical methanol, Keystone methanol may compete effectively against imports. Keystone would enjoy both tariff protection as a domestic producer and transportation cost advantages. At that point, the project could enter the chemical market.

\subsection{TRANSPORTATION OF METHANOL}

\subsubsection{TRANSPORTATION CHOICES}

The Keystone plant will produce approximately one-half million gallons of methanol daily. The transportation choices available for moving this product to market are truck, rail and pipeline. Each choice presents advantages that are appropriate for different potential customers and end uses. Table 3-12 outlines the advantages and customer type appropriate for each transportation choice. The final decision on transportation mode will be highly customer-dependent.

Truck transport is the most flexible system, but it is also the most expensive. It is only practical for relatively small quantities within a small radius, approximately 150 miles. Beyond this distance the cost would be prohibitive other than for specialized or intermittent uses.

Rail transportation represents a relatively inexpensive means of moving large quantities of methanol to specified locations on a regular basis. Discussions with Conrail and General American Transportation Company have determined that Keystone can move 900,000 gallon lots, 300 miles on a scheduled weekly basis for 4.5 cents per gallon. As the lot size is decreased, or regular scheduling is abandoned, the price of shipping by rail increases.

Pipeline is the lowest cost means of shipping large quantities of liquid product. The Keystone plant will be located within 8 to 24 miles of the major east-west pipeline corridor across Pennsylvania. Sun Pipeline and Buckeye Pipeline, in discussions with Keystone personnel, have stated that there are no major technical difficulties in shipping methanol through existing product 
TABLE 3-12

METHANOL TRANSPORTATION CHOICES

Transportation Mode

Truck

Rail

Pipeline
Characteristics

Flexibility

Small volumes (8000 gallons)

High cost/unit

Low capital commitment

Relatively inexpensive

Some flexibility

Variable lot sizes

Lowest operating cost

Substantial capital commitment Large lot sizes

Inflexible

Relatively quick shipment
Appropriate Customers

Close to plant

Chemicals

Neat fue 1

A11 markets
Refineries

Utilities

Customers with long-term

commitments 
pipelines. Use of a pipeline on a space available basis would allow Keystone methanol to reach ports and major metropolitan areas either to the east or west. Pipeline shipment would cost 3 to 4 cents per gallon.

Pipeline shipment has the disadvantage of being extremely inflexible. Reaching any customer not directly on the pipeline means either trans-shipping the product to truck or barge, or building a pipeline spur.

Truck transport will be used for some quantity of product marketed in the local plant area. Both logistics and cost preclude extensive distribution by truck. The remainder of the product will be shipped by the least expensive means, either rail or pipeline. This decision will also be highly customer-dependent.

\subsection{MARKET STRATEGY AND PLAN}

\subsubsection{TYPES OF RISK}

The market strategy developed for this project is based on the need to mitigate as much of the market risk as possible. In this case, there are two main types of market risk: (1) Price risk and (2) market availability risk.

Price risk is the risk that Keystone, in order to earn a reasonable return, will require a price higher than the market is willing to pay. Market availability risk is the risk that fuel uses for methanol will not develop as rapidly as projected and that Keystone will not be able to penetrate the methanol market without seriously disrupting the domestic market. The plan that has been developed to deal with these two risks depends on price guarantees and long-term contracts to market a significant portion of the Keystone output.

The only available market that makes use of long-term contracts is the utility market. This is also the market where methanol has the lowest value. The other markets discussed above value methanol more highly but do not presently make use of long-term supply contracts. 


\subsubsection{MARKETING PLAN}

The marketing plan being pursued for the project calls for the sale of 50 to 75 percent of the plant output to one or more utility customers with the remainder being sold in the gasoline blend market to refiners. This reduces the project's risk and the requirement for price support.

\subsubsection{Utility Customers}

Discussions that could lead to letters of interest are underway with a number of utilities. In most cases, a specific use for methanol fuel has been identified by the utility. In other cases, there is a general need to reduce oil usage or a specific need to obtain fuel for fuel cells. Each of these utilities could consume at least 50 percent of the keystone output in the identified specific area.

\subsubsection{Blend Market}

Keystone Project output not under contract to a utility will be marketed in the higher value gasoline blend market. Figure 3-5 displays the expected $r$ ange of values of methanol as an octane enhancer. The price that a specific refiner/blender would be willing to pay for octane enhancement depends on a number of factors previously identified. By the time Keystone begins production, it is expected that methanol will command a higher price in the blend market. If that is the case, little or no price support will be requ ired.

ARCO is using methanol as an octane enhancer for unleaded gasoline from their Philadelphia refinery. Sun (Marcus Hook) and Getty (Delaware City) appear to be planning for methanol use. The Keystone Project will offer them, and other northeast refiners, a secure supply of methanol at a competitive price. This market will grow as the need for a cosolvent decreases or available cosolvent supplies increase. 


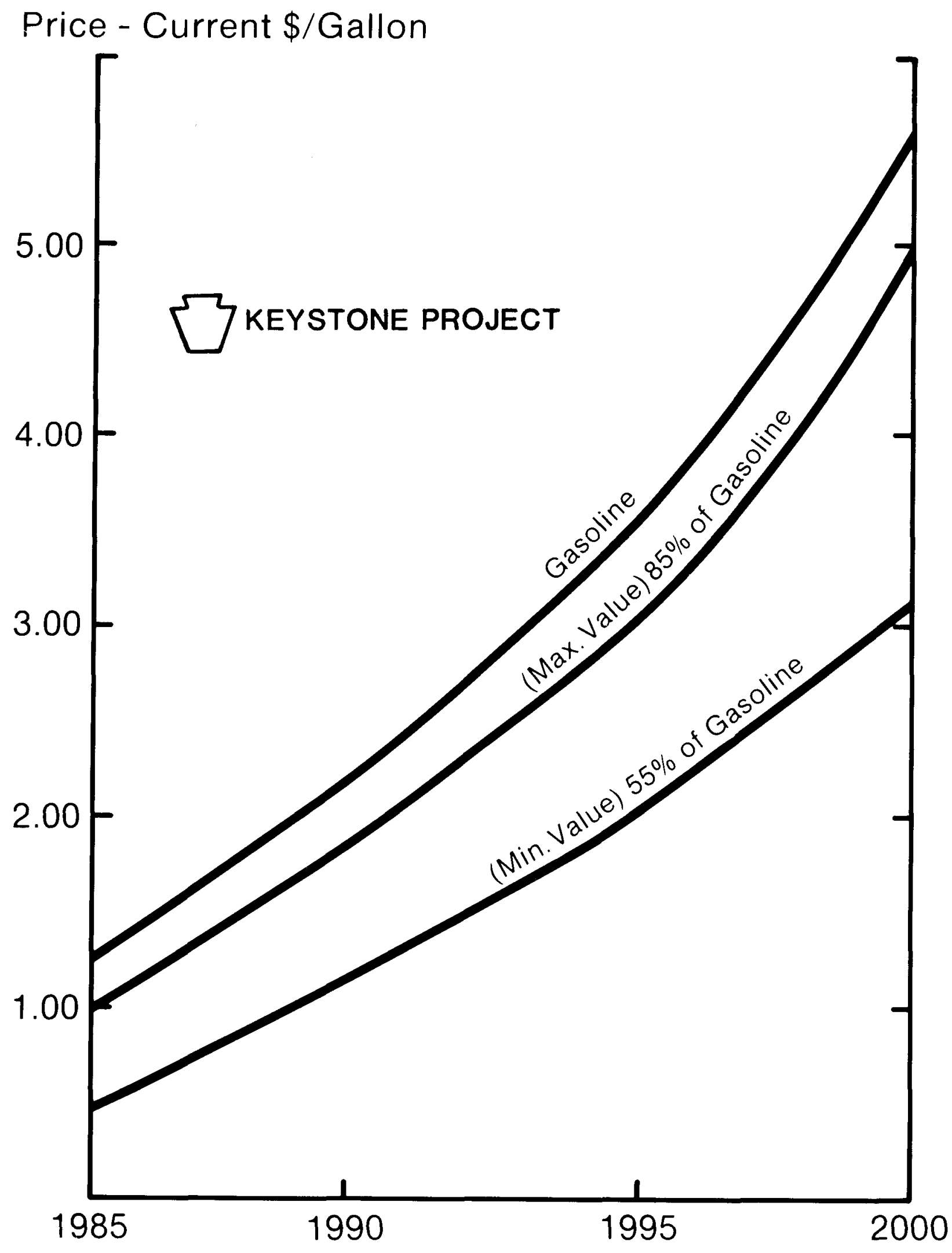

Figure 3-5 Expected Range of Values of Methanol as an Octane Enhancer 


\subsubsection{Neat Fuel and Chemical Market}

The neat fuel market should begin to develop in the 1990s. At that point, there will be sufficient supplies of methanol, if coal-based plants are developed, and fleet owners have sufficient experience with neat methanol to move with confidence to this alternative. The first fleets to convert will be those that are secure in their supply. Keystone will continue to promote neat fuel use in its market area.

Keystone does not plan to market any methanol in the chemical market prior to 1990. As the United States moves into an import position for chemical methanol, Keystone will compete with imports for the northeast market. No price supports will be required in this market.

\subsubsection{PRICING}

Barring major supply disruptions, no synthetic fuels project at the start is going to produce fuel at a price competitive with existing alternatives. The capital cost is not only high, but it is all "new" capital, undepreciated and fully escalated during construction. All major synthetic fuels projects will require some government subsidies at the present time.

\subsubsection{Chemical Market}

The value of methanol varies in the possible market segments outlined previously. Methanol will have the highest value in the chemical market. Due to oversupply, the market price will be set by producers' costs. These costs have been estimated through interviews with producers, estimations of future domestic prices on the basis of natural gas price projections and estimations of Canadian producers' prices based on their public testimony. The results of these calculations were shown in Figure 3-4. The Canadian price estimate includes the 18 percent tariff and an allowance for transportation to U.S. markets. The Canadian price estimate prescribes a 1 ine approximately 25 cents below domestic producers' desired price. The ultimate chemical market price will fall somewhere in the band between these two curves on the figure.

$4071 E$ 


\subsubsection{Low Percentage Blend Market}

The value of methanol in the low percentage blend market depends on numerous assumptions, such as the value of butane, the availability of crude, refinery operating rates, etc. It also changes from refinery to refinery. In general, work performed by Air Products and others has shown that methanol has a value ranging from 55 to 85 percent of the price of gasoline. At 55 percent, the methanol is basically being priced as an extender, while an 85 percent price can be justified by a refiner who is short on octane and crude. All these prices assume that any cosolvent used is priced equivalent to gasoline and that the consumer notices no difference in mileage with the blends. Figure 3-5 shows the anticipated range of methanol prices when used as a gasoline-blending agent.

\subsubsection{Neat Fuel Market}

Methanol as a neat fuel priced on a pure Btu basis would sell for 55 percent of the gasoline price. Methanol should be able to sell for a higher price on a Btu basis because of the efficiency gains possible due to the high octane and high heat of vaporization. Increasing engine efficiency allows the consumer to achieve equal miles per dollar even though the methanol is priced higher on a Btu basis. Efficiency gains of 15 to 30 percent are probable in the early years, with even higher gains possible in the future.

Offsetting this is the initial cost of conversion, the purchase premium, any extraordinary distribution costs and the problem of resale. Finally, the cost of any fuel additives for lubrication or safety must be added in.

The net of all these factors must be a price that offers the consumer an economic benefit from switching from petroleum fuels to neat methanol. This price will probably be 55 to 60 percent of the price of gasoline. 


\subsubsection{Utility Market}

Pricing in the utility market will be on a Btu-equivalent bas is in competition with distillate or firm-contract natural gas. Based on conversations with utilities, Keystone determined that some premium will be allowed for pollution effects and security of supply. This market would be willing to pay 10 percent above the cost of distillate for methanol. In general, utilities will be the lowest valued market for methanol.

\subsubsection{Comparison Between Market Segments}

Figure 3-6 displays the prices described above, as well as the FOB Keystone price. Over time, the Keystone price moves into a position in each of these markets where a subsidy is no longer required. The figure shows the price of methanol compared to the value of methanol in fuel applications. The value range as a blend is taken from data in Figure 3-5, while the value as a utility fuel is based on an environmental performance premium of 10 percent over distillate price. The price range of methanol lies between an upper boundary (a price forecast based on strong demand, escalating natural gas prices, reasonable profit margins and low offshore imports) and a lower boundary (a Pace Engineering price forecast based on plentiful supply of reasonably priced natural gas, competition from offshore methanol and low profit margins). Keystone can effectively compete against the upper bound methanol by 1990 and against lower bound methanol by 1996.

\section{5 .4 CONCLUS ION}

The project's approach to supplying the methanol market as described above is expected to accomplish four objectives:

(1) Minimize market $r$ isk through acquisition of a long-term contract.

(2) Reduce required price supports by marketing some portion of the plant output in higher valued markets.

(3) Establish the viability of coal-based methanol in a number of markets.

(4) Establish footholds in a number of markets to ease plant expansion. 


\section{乙KEYSTONE PROJECT}

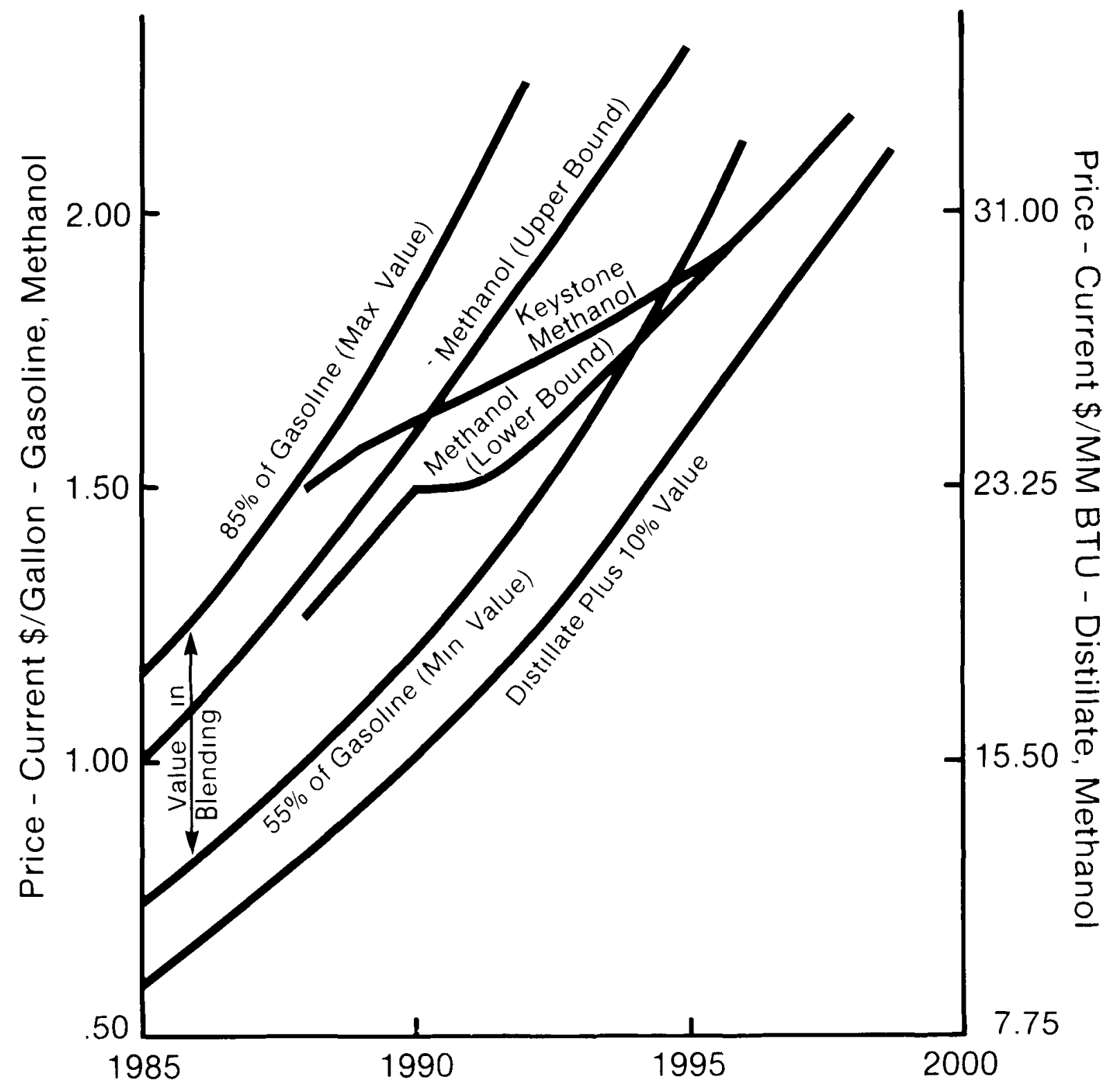

Figure 3-6 Required Keystone Methanol Price Compared with Various Market Prices 


\subsection{REGULATORY AND LEGISLATIVE IMPACT}

\subsubsection{UTIL ITY MARKET}

Existing clean air standards limiting emissions from power plants are a major reason for the use of methanol in direct combustion. Methanol will be more desirable as these regulations are tightened.

Any contract that Keystone signs with a utility that calls for the purchase of methanol at a premium over other available fuels will be scrutinized by the state public utility commission involved. The utility, in conjunction with Keystone, must convince the commission that capital and operating cost savings justify the premium price for methanol.

\section{6 .2 BLEND MARKET}

Existing EPA regulations and vapor pressure standards complicate the use of methanol in gasoline. The EPA must approve any substance that is added to unleaded gasoline. To date, they have refused to issue a broad approval for methanol and oxygenates and have only issued exemptions for particular combinations of methanol and cosolvents. This reduces competition and innovation in the market.

The EPA's mandate is to control air pollution levels from automobiles and to control lead levels in unleaded gasoline. By decreasing allowable lead levels, they increase the impetus to add methanol. The EPA could do much to encourage the use of methanol by issuing a blanket exemption for oxygenated fuels.

The vapor pressure regulations that gasoline must meet require the backout of butane from the gasoline pool when methanol is added. This reduces the value of methanol in blends. These regulations have been in place for many years and are not expected to change. 


\subsubsection{NEAT FUEL}

In contrast to the blend market, the EPA enthusiastically supports the use of neat methanol fuel in the transportation sector. Neat methanol produces very low levels of all controlled pollutants.

\subsubsection{STORAGE AND HANDL ING}

Methanol is a common industrial chemical that has been shipped and stored all over the country for decades. The requirements for safe handling are well known.

\subsubsection{LEGISLATIVE ACTION}

The Pennsylvania Legislature has had several bills introduced that are pertinent to encouraging the use of methanol for utility and vehicle fuel.

Several states offer tax incentives for blending methanol derived from coal into the gasoline pool. Keystone, with members of the coal industry and the Pennsylvania Farm Association, is assisting with the development and justification of legislation to provide tax incentives for methanol and ethanol blends in Pennsylvania. Economic analysis has shown that the cost/benefit ratio for up to $3 \not$ per gallon of ethanol or methanol blended into gasoline is decidedly advantageous to the Commonwealth. Several legislators have expressed interest and strong support for introducing the appropriate legislation in the 1983 session of the Legislature. The enactment of a partial road tax waiver of $3 \not$ per gallon will aid in developing the market for Keystone methanol.

The Surface Transportation Act of 1982 included a provision for the exemption of $9 \notin$ per gallon for alcohol fuels containing at least 85 percent methanol, ethanol or other alcohols not derived from petroleum or natural gas. This tax waiver should provide a significant incentive for the sale and use of neat methanol for motor vehicles. 


\subsection{BY-PRODUCT MARKETS}

The markets for Keystone Project by-products are briefly discussed in this section.

\section{7 .1 CARBON DIOXIDE MARKET}

\subsubsection{Strategy and Market Plan}

The Keystone $\mathrm{plant}$ produces two streams of carbon dioxide $\left(\mathrm{CO}_{2}\right)$ in its operations. The first stream contains 1000 tons per operating day of high purity $\mathrm{CO}_{2}$. Approximately 200 tons per day from this stream are required to support the gasification plant operation. The second stream contains 2000 tons per operating day, composed of 85 percent $\mathrm{CO}_{2}$ and 15 percent nitrogen (NO). This stream can be recovered and compressed to super-critical state for shipment by pipeline. The stream can also be safely vented to the atmosphere.

Keystone market studies have shown that there is an existing demand for 1185 tons per day of liquid $\mathrm{CO}_{2}$ in the Keystone market area. In addition, there is a large $\mathrm{CO}_{2}$ market that is not being exploited for two reasons: (1) Lack of consumer knowledge of the benefits of using $\mathrm{CO}_{2}$ for various industrial applications and (2) lack of $\mathrm{CO}_{2}$ supply. The Keystone market area, like most of the United States, is in a $\mathrm{CO}_{2}$ supply-constrained condition. The marketing strategy for Keystone is two-fold: Make additional $\mathrm{CO}_{2}$ supplies available, and promote the use of $\mathrm{CO}_{2}$ in applications where other, less desirable processes or chemicals are currently being used.

The Keystone Project will not enter the $\mathrm{CO}_{2}$ marketing and distribution business. The product will be sold as a liquid on a wholesale basis, FOB, the Keystone plant. Long-term contracts should be available on this basis.

The 2000 tons per day of low purity $\mathrm{CO}_{2}$ stream could be marketed in the Appalachian oil fields for use in enhanced oil recovery projects. The current low price of oil and the cost of constructing a pipeline to reach the candidate fields make this venture unattractive at this time. Keystone 
Project management will monitor this situation with the possibility that the economics for $\mathrm{CO}_{2}$-enhanced $0 i 1$ recovery may improve in the latter half of this decade.

\subsubsection{Industrial Markets}

The industrial market for $\mathrm{CO}_{2}$ can be broken down into three basic segments: (1) The existing $\mathrm{CO}_{2}$ market; (2) existing $\mathrm{CO}_{2}$ applications currently served by other processes; and (3) new applications. Potential for development exists in each of these three areas in the Keystone market area.

Such applications as beverage bottling, welding supply, dry ice and chemical manufacture are included in the existing $\mathrm{CO}_{2}$ market. An application that appears to be unique to Ohio, recarbonation of potable water for municipal water companies, is also included. The combined market for these uses is approximately 188,000 tons per year with an average growth rate of approximately 5 percent.

The second segment, existing $\mathrm{CO}_{2}$ applications currently served by other processes, offers the best chance for Keystone market penetration. In many cases, replacing the current processes with $\mathrm{CO}_{2}$ offers an economic or manufacturing advantage. $\mathrm{CO}_{2}$ use in these applications is constrained in the keystone market area only by the tight supply situation. Included in this market segment are food processors currently using nitrogen or mechanical freezing, well servicing companies that are using nitrogen for oil or gas well stimulation and chemical producers that are using $\mathrm{CO}_{2}$ substitutes in their processes. The potential in this segment is estimated to be about 473,000 tons per year with an average growth rate of 15 to 20 percent.

The third market segment, new applications, includes bottom stirring in steel production, super critical distillation and carbon dioxide/coal slurry pipelines. Although the latter two uses are still in the bench-scale test stage, the use of $\mathrm{CO}_{2}$ in steel production is in the early stages of commercial introduction. The size of the market in this type of new application is difficult to estimate. In the case of the steel industry, the 
estimates for use are 65,000 tons in 1986, possibly growing to 490,000 tons by 1996. Should this growth materialize, the size of the market will be supply-constrained.

\subsubsection{0il Field Applications}

Carbon dioxide is used in the oil fields for two purposes: $0 i 1$ and gas well stimulation or fracturing and enhanced $0 i 1$ recovery. Well stimulation is included in the preceding section defined as applications currently served by other processes. The competing process in this case is the use of $n$ itrogen to energize fluid recovery from the formation. Promoting $\mathrm{CO}_{2}$ use is mostly a matter of making $\mathrm{CO}_{2}$ available in the oil field. There is already growing interest in using $\mathrm{CO}_{2}$ now that additional supplies are available from the Columbia Gas plant in Charleston, West Virginia.

Enhanced oil recovery (EOR) is the process of recovering a portion of the residual oil that is left in the ground after primary and secondary recovery. In the Appalachian Basin, this residual oil averages 80 percent of the original oil in place. Injection of $\mathrm{CO}_{2}$ is one method used to recover this additional oil. Several technically successful projects have been conducted in West Virginia. This study identified two potential EOR applications in West Virginia and three potential applications in Pennsylvania.

Supplying Keystone $\mathrm{CO}_{2}$ to EOR projects would require construction of a pipeline from the plant to the fields to ship the 2000-ton-per-day low purity stream. Although construction is technically feasible, a thorough study of economics based on current and projected low prices of $0 i 1$ does not justify this effort. This situation could change rapidiy. A 2- to 3-year lead time would be required to construct all facilities needed to ship $\mathrm{CO}_{2}$ to the oil fields for EOR. Under the circumstances, Keystone management will continue to monitor the situation, which represents an opportunity to add significant revenues to the Keystone Project.

\subsubsection{Competition}

There are 2400 tons per day of existing $\mathrm{CO}_{2}$ production capacity that overlaps the Keystone market area (Figure 3-1, Map 1). The study indicated no planned capacity additions, with the exception of approximately 350 tons per 
day at the South Point ethanol plant in South Point, Ohio. In fact, it is probable that some of the existing capacity will be retired before the Keystone plant begins operations. One of the primary sources of $r a w \mathrm{CO}_{2}$ is the waste stream of ammonia production plants. As noted in figure 3-1, 900 tons of existing capacity in the keystone market area are supplied by ammonia plants. As natural gas prices rise, the production from many of these plants is expected to be replaced by imports.

\subsubsection{Product Distribution and Market Area}

Carbon dioxide is distributed in liquid form by truck or rail to end users who provide on-site storage for the product in all cases except well stimulation. In well stimulation, the product is used directly from the truck. Truck transports carry 20 tons of $\mathrm{CO}_{2}$ per load. In general, the economic delivery radius for trucks is 150 to 200 miles. In the case of a supply-constrained market, the product is often shipped further.

Alternatively, the product can be shipped in 85-ton rail carloads. This mode could be used if Keystone chose to serve the New York City and New Jersey market. The product would most likely be shipped to trucks for local delivery.

The Keystone primary market area for $\mathrm{CO}_{2}$ is the area within a 200-mile geographic radius of the plant site. In a regional market that is supply-constrained, such as the Northeast, product prices are such that shipment beyond this radius can be justified. Each major customer opportunity must be evaluated on an individual basis.

\subsubsection{SULFUR MARKET}

The Keystone plant will recover approximately 90 long tons per day of elemental sulfur. As part of the by-product market study, a brief overview of the sulfur market was conducted to determine the marketability of this product.

The sulfur market is tied tightly to the fertilizer industry, where some 60 percent of total sulfur is consumed as sulphuric acid. The sulphuric acid is reacted with phosphate rock to produce phosphoric acid for use in phosphate 
fertilizers. The fertilizer industry, as well as other major sulfur-using industries such as chemicals and steel, is in a major slump. This has led to a recent decline in sulfur prices and major cuts in sulfur production.

Elemental sulfur is produced in two ways. It is either recovered from other processes, as in the Keystone case, or it is mined using the Frasch process. Producers of recovered sulfur produce sulfur as an activity incidental to their primary business activity. They vary their production of sulfur oniy in response to the amount of sulfur in their $r$ aw material, or in response to changes in demand for their primary product. Frasch producers must vary the amount of sulfur they produce to meet changes in demand in the sulfur market. The number of producers is small, and they have demonstrated the ability to control sulfur prices. As the 1980's progress, the supply of sulfur from Frasch producers is expected to decline. The Pace Company predicts that sulfur prices will top $\$ 190$ per ton by the Keystone startup date, with prices moving over $\$ 200$ per ton after 1990 .

The 90 tons per day that Keystone will produce is unimportant in the context of the total sulfur market. Discussions with 01 in Chemical have identified a need for sulfur at their Baltimore sulphuric acid plant. Shipment will be by rail. Their alternative source is western Canada or the Gulf coast of the United States.

\subsubsection{AMMONIA MARKET}

The Keystone plant's first module ammonia production of 7.4 tons per day, or even full plant production of 37 tons per day, is insignificant when compared with the 18 million tons produced in the United States in 1981.

Ammonia growth is 2 to 3 percent per year. Most production is from natural gas. As U.S. gas prices rise after decontrol, an increasing portion of domestically consumed ammonia is expected to be imported. The price for ammonia will also rise, reaching an expected $\$ 370$ to $\$ 410$ per ton by 1985 .

Bower Ammonia and Chemical Company of Philadelphia was contacted and expressed a desire to purchase Keystone's entire production. 


\section{SECTION 4.0 \\ PROCESS LICENSING AND AGREEMENTS}

Progress by the Keystone Project in defining, obtaining and negotiating all required or proposed agreements is summarized in this section. In addition, the project's low potential for litigation is discussed; the project's right of access to the selected facility site is supported; and essential facts establishing a high degree of replicability for the project are reviewed.

\subsection{SUMMARIES OF AGREEMENTS OR PROPOSED AGREEMENTS}

\subsubsection{PROCESS LICENSES}

The Keystone Project uses several of the following catalysts and processes in addition to the westinghouse gasification process. The use of each requires a license agreement or similar arrangement:

- Acid Gas Removal

Selexol (Norton Company)

Rectiso 1 (Lotepro Corporation)

Benfield (Union Carbide Corporation)

- Sulfur Recovery

Recycle Selectox (Ralph M. Parsons Co.)

Claus (Ralph M. Parsons Co.)

Stretford (Ralph M. Parsons Co.)

- Tajl Gas Cleanup

Beavon Sulfur Recovery Process (Ralph M. Parsons Co.)

Beavon Sulfur Recovery/Methyl Diethanolamine Process (Ralph $M$. parsons Co.)

- COS Hydrolys is

United Catalysts (United Catalysts Inc.)

Haldor Topsoe (Haldor Topsoe Inc.)

- Shift Conversion in Presence of Sulfur

United Catalysts (United Catalysts Inc.)

Haldor Topsoe (Haldor Topsoe Inc.) 
- Ammonia Recovery

PHOSAM-W (United States Steel Corp.)

- Methanol Synthesis

ICI Low Pressure Process (Imperial Chemical Industries)

- Gasification

Pressurized Fluidized Bed (Westinghouse Electric Corporation)

Licensors for the processes or catalysts listed above have expressed in writing their willingness to license their processes or provide their catalysts on a reasonable basis. In addition, examples of standard agreements covering several of the processes have been obtained, allowing initial evaluation and discussions of business arrangements between project representatives and licensors.

Westinghouse Electric Corporation, as licensor of the gasification system, will provide its license to the project under reasonable terms and conditions. The term will be at least as favorable as those prevailing for other commercial licensing activities by Westinghouse at the time the final license is negotiated.

\subsubsection{PERFORMANCE GUARANTEES}

Performance guarantees for the processes result in increased confidence in the technical aspects of the overall project. Performance guarantees are an important part of the process agreements to be negotiated with many of the licensors. With some licensors, the performance guarantee represents a separately negotiated agreement for any number of aspects of individual process performance.

Westinghouse will offer reasonable performance guarantees for the gasification system. The content of these guarantees is still being developed. 


\subsubsection{PROJECT FINANCING, PROJECT AGREEMENTS AND PARTNERSHIP AGREEMENTS}

Numerous agreements are required for financing different phases of the project, for procuring project materials and services and for describing partnership rights and obligations of the various project sponsors. Discussions are being held by project team members and outside companies who may play a key role in areas relative to such agreements. Although no agreements have been fully negotiated at this stage, current team members provide talent and experience for performing the contracts or for obtaining outside assistance, such as for project financing.

\subsection{LITIGATION}

Based on an investigation of major issues, there is little likelihood of any litigation resulting from the Keystone Project. The issues investigated include the following:

- Process licenses

- Water rights

- Mineral rights

- Land availability

- Utility right-of-way easements

- Environmental compliance

No litigation has been undertaken or is pending regarding these issues, nor is any expected. Legal issues that might affect overall feasibility, cost or schedule of the project are monitored by project managers.

\subsubsection{PROCESS LICENSES}

- Issue

Litigation on process licenses could occur if a license to incorporate a particular process into the design on satisfactory terms could not be obtained. 
- Litigation is unlikely

Licensors for major processes for the project have expressed in writing their willingness to license or provide their catalysts on a reasonable basis.

The project team includes highly experienced engineering and construction firms with expertise in the process licensing field.

Processes to be used in the project are readily definable; no accidental omissions are expected.

\subsubsection{WATER RIGHTS}

- Issue

Litigation on water rights could result from disputes over access to or amounts of water to be drawn from specific sources.

- Litigation is not expected:

Manufacturers Water Company will supply Quemahoning Reservoir water for project purposes.

Manufacturers Water Company will obtain the right-of-way for the water supply lines.

\subsubsection{MINERAL RIGHTS}

- Issue

Litigation on mineral rights on the site primarily involves prevention of subsidence of vital plant structures and equipment. 
- Litigation is unlikely:

Coal reserves in the plant area are economically unsuitable for mining, because they are less than 7 inches thick.

Past deep coal mining operations occurred on the extreme southern end of the site, well away from the anticipated location of any plant structures.

Mineral rights have been obtained for all key property acquisitions.

No underground mining has occurred under any of the proposed construction areas.

\subsubsection{LAND AVAILABILITY}

- Issue

Litigation on land availability could result from the inability to procure land necessary for the project.

- Negotiations have been successfully concluded:

A11 1 and owners with in the site boundary have expressed a willingness to negotiate sale.

Options for all tracts of 1 and have been obtained.

\subsubsection{OTHER LITIGATION POTENTIAL}

- Issues

other litigation could result from environmental matters and right-of-way access to electrical power and natural gas. 


\section{- Litigation is un likely:}

Preliminary studies of environmental aspects of the project indicate project compliance with local regulations.

Announcements of the project have met with broad public support.

Discussions with suppliers of electricity and natural gas are proceeding.

The utilities will assist the project in obtaining access rights.

\subsection{RIGHTS OF ACCESS TO LAND}

The discussion of 1 and ownership in this section shows that the proposed Cairnbrook site is available for the project. All twelve landowners within the site boundary have agreed to sell their property and have executed option contracts for a period of 18 months.

\subsubsection{CURRENT STATUS OF SITE OWNERSHIP}

The project site includes approximately 1280 acres and contains 20 separate parcels owned by 12 parties. Parcel size ranges from 1 acre to 218 acres. The area is predominantly vacant land, some of which has been strip-mined, although there are four residences. The properties have recently been appraised.

All owners have executed an option that will allow future purchase of their land by the project. All options plus extensions are for an 18-month period. These options provide the project with assured legal rights to the site.

All necessary land options for the Cairnbrook site have been signed, and the earliest expiration date for any of the options is October 1983. 


\subsection{REPL ICAB ILITY OF PROJECT}

The potential for replication of the Keystone plant in other locations with in the United States is based on the following project characteristics:

(1) The plant's modest size limits capital investment, operating costs and financial risk, but it is large enough to achieve economies of scale and provide meaningful amounts of product.

(2) The plant's modular concept allows step-wise expansion as economic and market conditions warrant. The use of proven technology in the plant's design and operation limits risk and lowers costs of replication in other locations.

(3) Feedstock flexibility is provided by the Westinghouse gasifier, which can successfully process essentially all U.S. coals: Caking or non-caking, high or low ash, high or low sulfur, reactive or non-reactive and lignite to bituminous coals.

(4) The project's gasification technology is domestically developed, and Westinghouse intends to sell gasification systems to interested parties. To minimize environmental concerns, the gasifier operates at temperatures high enough to consume tars and oils, yet low enough to avoid major materials selection problems. The high pressure operation also increases throughput and provides one of the most efficient gasification processes available today.

(5) Requirements for steam use in the plant are low because the Westinghouse gasification process has modest steam needs compared to both fixed and entrained bed gasifiers. This is a major advantage for synthetic fuel plants in sections of the country where water is scarce. 
(6) The Keystone Project concept can be readily adapted to other products. Medium-Btu gas can be the final product by eliminating the methanol production step, or gasoline can be produced by adding a final methanol-to-gasoline conversion step.

In summary, the Keystone Project has no restrictions in either resource base, site, technology, product or project scope that inherently limit its ability to be replicated at numerous locations in the United States. 
APPENDIX A

PR IME ENGINEER ING CONTRACTOR -- PROJECT EXECUTION PLAN

$4078 E$

A-1 
This Appendix presents the Project Execution Plan to be followed by the prime engineering contractor for the design phase of the Keystone Project. The plan is divided into four sections:

- Objectives and Functions

- Organization

- Controls

- Management Master Plan

\section{A.I OBJECTIVES AND FUNCTIONS}

The objectives and functions of the engineering contractor's Project Management approach are described in this section.

\section{A.1.1 PROJECT MANAGEMENT OBJECTIVES}

The engineering contractor (EC) will execute the Project under a strongly centralized Project Management concept. The following objectives, which are fundamental to success, will apply:

- Design facilities within the established time schedules.

- Maintain Project costs within established budgets.

- Assure plants and systems meet Project requirements for safety, efficiency, and reliability

These objectives will be accomplished using professional Project Management techniques to prepare, integrate, coordinate and execute the overall Project activities. 


\section{A.1.2 PROJECT MANAGEMENT FUNCTIONS}

Major functions of the EC's Project Management services will include:

- Develop with the Keystone Project Team the overall detailed scope of the Project.

- Establish and coordinate uniform Project procedures with other members of the Project Team.

- Establish the overall Project plan and schedule.

- Establish the overall Project budget.

- Develop a cash flow structure for the Project.

- Coordinate definitive procedures for Project cost controls with other members of the Keystone Project Team.

- Coordinate and manage engineering design in accordance with Project scope, schedule and procedures.

\section{A.2 ORGANIZATION}

Successful execution of the Project is dependent upon the establishment of a knowledgeable, centrally organized, responsible and professional Project Task Force to assure efficient, effective, and harmonious working relationships between all parties involved in the Keystone Project.

The EC will use a Project Task Force consisting of a Project Manager aided by a staff of key personnel from Project Management, Engineering, Control Engineering, Procurement, and Administrative disciplines.

The EC Project Task Force will include the following elements:

- An integrated team of Project Management and skilled engineering personnel who are responsible for manaing all engineering and design work, the preparation of purchase specifications, and the technical selection of equipment and materials. 
- Specialist support personnel to provide necessary project control services such as planning, scheduling, cost engineering, estimating and accounting.

- Procurement, expediting, inspection traffic and logistics control specialists at the home office.

Following are further details of the proposed project execution methodology for the Keystone coal to methanol project. The Engineering Project Task Force Organization Chart has been included at the end of this section.

\section{A.2.1 PROJECT TASK FORCE MANAGEMENT}

The Project Task Force Management will be permanently assigned personnel who will be conveniently situated together and readily accessible for good communications with other members of the Project Task Force, Keystone Team members, suppliers, subcontractors and site forces. The Project Task Force Management will include the following key personnel:

- Project Manager

- Administrative Manager

- Technical Manager

- Control Manager

- Procurement Manager

The key management positions identified above will be assisted by other Project Managers, engineering disciplines and specialists as required for the efficient management and control of the project. The nucleus of the proposed Project Task Force organization for the project with key functions have been identified by discipline responsibility. 
- Responsible to the Keystone Project General Manager for the overall planning, organization, execution and control of the entire Keystone Project design effort, including management of:

- process design

- detailed design

- procurement of materials and equipment.

- Directs development of the Management Master Plan.

- Ensures that Project objectives are established and met in a professional and economical manner consistent with efficient utilization of resources.

- Responsible for establishing and maintaining Project procedures for execution of the project including:

- Project Management and Control Manual

- Project Procedures Manual.

- Ensures that report procedures are established and maintained to fully inform Project team members as to the status and forecasting of the Project. Issues monthly Project status reports.

- Accountable for the completion of the design effort within the established time frame and budget, and in accordance with Keystone Associates quality standards and specifications.

- Responsible for administration of all contracts and whenever needed, for obtaining legal advice on contractual matters affecting proper Project execution. 
- Initiates, in cooperation with any subcontractors, preparation of Project procedures covering communications, drawing and specification approvals, document distribution, changes in the scope of work, procurement and other working procedures.

- Assigns one of $h$ is subordinates to act on his behalf as required.

\section{Administrative Manager}

Reports to the Project Manager.

- Assists the Project Manager with preparation of Project Procedures including the Project Management and Control Manual and Project Procedures Manual.

- Assists with preparation of report procedures and prepares monthly Project Status Reports as instructed by the Project Manager.

- Administers contracts and obtains legal advice on contractual matters as instructed by the Project Manager.

- Responsible for all Project Services for the task force, including:

- office supplies

- telephone services

- mail services

- secretarial pool

- filing systems

- $\quad$ office equipment

- reproduction

- office layout

- travel arrangements

- The Administrative Manager will be assisted by qualified personnel selected for specific work assignments. 
Technical Manager

Reports to the Project Manager.

- Responsible on behalf of the Project Manager to maintain "Technical Control" for all Project design and for all Project engineering. Ensures that quality control standards are adhered to for engineering.

- Leads in the development of engineering strategy and directs development of the Engineering Management Plan.

- Chairs technical control meetings to assure various Project objectives and quality standards are carried out.

- Oversees the development of the front end engineering packages.

- Ensures that consistent technology and similar methods of Project execution are incorporated.

- Assists in the development of the systems and techniques for monitoring the various engineering contractors.

- Directs the development of Project specifications.

- Supervises and reviews interoffice technology transfer to the Project.

- Assists in the transfer of front-end packages to the detail engineering contractor.

- Ensures that the necessary technical specialists are available to resident Project managers when required.

- Handles specialized trouble shooting or evaluation.

- Institutes and manages special task forces for special problem solving. 
- Has overall technical responsibility for the Project.

- The Technical Manager will be assisted by the Project Engineers in each of the Task Force Units.

\section{Control Manager}

Reports to the Project Manager.

- Responsible for all:

- Project planning

- Scheduling

- Estimating

- Budgeting

- Cost Engineering

- Leads the development of the Controls Plan portion of the Management Master Plan.

- Monitors schedule progress and budget compliance.

- Makes forecast projections for the Project Manager's consideration using accepted planning, scheduling and cost engineering techniques.

- Controls all invoicing, payments and Project accounting.

- The Project Control Manager will be assisted by the Control Coordinators, Planner(s), Scheduler(s), Schedule Reporter(s), Estimator(s), Budget Clerk(s), Cost Engineer(s), Cost Reporter(s), and Accountant(s), each qualified to administer the responsibilities of their specific job assignment. 
Procurement Manager

Reports to the Project Manager.

- Leads the development of the Project Material Management Plan.

- Coordinates development of the vendors list and subsequent revisions.

- Investigates and directs the placing of blanket orders and bulk orders.

- Develops procedures which coordinate contractors and subcontractors and ensures the following are implemented:

- Buying

- Expediting

- Inspection

- Traffic

- Coordinates the establishment of purchase order format.

- Establishes field procurement procedures in accordance with total Project requirements and the construction contractor.

- Establishes Project terms and conditions.

- Directs the establishment of total procurement reporting system and monitors and identifies problem areas in the following:

- Inquiry status

- Purchase order status

- Expediting reports

- Inspection reports 
- Directs the inquiry and procurement of critical long delivery equipment.

- Directs the establishment of priorities in vendors' shops to ensure Project schedule is met versus each individual contractor trying to get $h$ is work out first.

- Interfaces with the construction contractor to coordinate traffic on material and equipment shipments involving obtaining the necessary permits, checking insurance coverage, and expediting receiving documents.

- Establishes system for prompt client approval of purchase and change orders.

- Directs development of approximate equipment delivery times for early scheduling effort.

- Participates in establishment of a vendor data procedure for the Project and ensures that vendor data is expedited and obtained as needed.

- The Procurement Manager will be assisted by the Procurement Coordinators, Buyers, Expediters, Inspectors, Traffic Specialist(s) and Vendor Data Control Clerk(s), each qualified to administer the responsibilities of their specific job assignment.

\section{A.2.2 TASK FORCE UNITS}

The Keystone Project is divided into a finite number of process-related technology units. Within the overall Project Task Force, a task force unit will be established for each of these process technology units. These task force units will be staffed with personnel who will be situated together and readily accessible to Keystone Team Members, suppliers, subcontractors, and site forces. The task force units will each include the following key personnel: 
- Project Manager

- Project Engineer(s)

- Process Engineer(s)

- Design Engineers

- Procurement Coordinator

- Control Coordinator

Engineering personnel such as metallurgists and equipment specialists will join the task force units on an "as needed" basis.

listed above as the "Task Force Units Execution Staff."

\section{Task Force Project Managers}

Each task force unit will be headed by a Project Manager who is responsible for the day-to-day operation of his specific process technology unit. His duties and responsibilities are as described for the overall Project Manager, except that they pertain only to the area of his assignment. He will have a complete staff including process, design, Project engineering, procurement coordinator, control coordinator, and administrative personnel.

\section{Project Engineers}

The Project Engineers report to the Task Force Project Manager and complement his activities in the utilization of all resources available with in the total organization. The Project Engineers are responsible for the technical and timely execution of the work. The very important assignment of Model Coordinator, responsible for all data input and output, reviews and compliance to the model procedures for model design, is made from the Project Engineering group. In addition, a Technical Manager assigned to the Project Task Force Management Staff monitors uniformity and quality of design for the various areas via the Project Engineers and conducts the formalized Technical Reviews for PFDs, P\&IDs and General Arrangements by Engineering Supervision. A Lead Project Engineer is assigned in each task force unit to supervise these activities. 
Process Engineers are assigned to the Project team to provide basic process design, PFDs, equipment and instrument data, with responsibilities to interface with other Process Engineers, Project Engineers and Design Engineers in the review of process documents, drawings and vendor data of process equipment to ensure the proper engineering techniques are being followed and that the philosophy, intent of purpose, and standards of quality specified in the Project scope are maintained. A Lead Process Engineer is assigned to each task force unit to supervise these activities.

\section{Design Engineers}

Design Engineering is produced by six major disciplines: Civil/structural, Mechanical, Electrical, Instrumentation, Piping and Vessels/Heat Transfer. Model design is provided by the Piping discipline. During the Project Definition stage of work, a specialist group is utilized to prepare PFDs, P\&IDs and General Arrangements. Each discipline is assigned a Group Leader who is responsible for timely performance of his discipline's work. The Group Leader reports within his task force unit to the Project Engineers and $h$ is group's technical quality is also monitored by the respective discipline Chief Engineers.

\section{Procurement Coordinator}

The Procurement Coordinator reports to the Project Manager in each task force unit and is responsible for the procurement activities. His performance is monitored by the Procurement Manager. He is assisted by buyers/expediters who solicit quotations, prepare bid tabulations, place purchase orders and subcontracts, and expedite deliveries. All are coordinated and assembled in a way to present the Project Manager with a clear analysis of Project commitments. Inspection, although not under the responsibility of the Procurement coordinator, is performed under the standards and procedures established by the central procurement Department in conjunction with various engineering disciplines, with the assignment of priorities established by the Project work $\mathrm{plan}$ and time schedule. 
The Control Coordinator reports to the Project Manager in each task force unit and is responsible for execution of all control engineering, including coordinating and monitoring cost, cost engineering, planning, scheduling, estimating, and other control activities of the Project. His performance is monitored by the Control Manager, and he is assisted by and directs the operations of the Project control personnel, i.e., the Estimator, Planner, Scheduler, Cost Engineer and Cost Reporter. His responsibilities include; participation in the establishment of cost budgets, time schedules and cost forecasting for the Project, provide direction and coordination for all control activities to comply with company policies and procedures to fulfill contractual commitments within budget and schedule provide recommendations of corrective action needed to accomplish Project objectives, provide trending and monitoring compliance for all project budgets and estimates, for home office costs, material and equipment costs, subcontract costs and construction direct and indirect costs, and direction in preparation of special progress reports, cost reports and cash flow reports as required by the Project Manager or Control Manager.

\section{A. 3 CONTROLS}

In this section, the system of Project controls that will be employed for the Keystone Project to keep it on schedule, within budget, and to the standards of quality established by the project specifications is briefly described.

\section{A.3.1 CONTROL OBJECTIVES}

A system of integrated Project controls provides for:

- A progressive estimating procedure to establish Project costs .

- Trending of Project costs to detect any significant changes on a timely basis through the completion of definitive cost estimate. 
- Effective Critical Path Method (CPM) scheduling of the work.

- Measuring and reporting progress and costs for all phases of the work and comparing these to plans and budgets.

- Controlling procurement status of equipment and materials to maintain Project schedules.

- Effective control of bulk materials and equipment quantities.

- Analyzing and reporting productivity.

- Early identification of problems and deviations from plans or budgets.

- Keeping Keystone management and the Project Team informed on progress and costs throughout the design and engineering phases of the work.

Functions described in this section include the following:

- Planning and Scheduling

- Cost Reporting and Cost Engineering

- Estimating

\section{A.3.2 PLANNING AND SCHEDUL ING}

The Planning and Scheduling system and related tools to be used involve planning the job through the CPM technique, followed by a rigorous scheduling and reporting system utilizing data processing techniques and aids, as required.

These control systems provide the plan that indicates "when" work tasks should be accomplished; the important consideration of "how" they should be performed can then be established. 
A total Project Logic Network is assembled by the planner from information supplied by engineering and construction and is utilized as the Master Plan for all work activities. The Logic Network portrays detailed interfacing between related functions, and milestone objective schedules are developed for measuring progress.

In general, the CPM planning and scheduling system has four goals:

1. Early Project coordination and understanding of objectives through network planning and calculations that reflect realistic target dates.

2. Communications in the form of Project schedules that establish "timing" for the performance of each significant task in such a way to allow maximum economy, and in a form that is clearly understood by a 11 concerned.

3. Controls in the form of timely and accurate reports which clearly reflect the status of the Project schedule are available to any level of Management responsibility in the degree of detail desired.

4. A continuous analys is of performance enables forecasting possible trouble areas well in advance so that maximum time is allowed to determine the most effective corrective action.

The Planning and Scheduling services (Control Engineering) provided are network-based computer systems that have been utilized and proven on Projects of various complexities.

The following items illustrate the principal aspects and documents of the Control System.

- Early Activity Schedule - Prepared within the first weeks of the project. Activities that will start during the first four to six weeks are listed. 
- Logic Diagram - The planner develops the complete CPM logic diagram depicting engineering and procurement in detail with major milestones for construction.

- CPM Computer Print-out - Each activity is assigned a start and completion date by utilizing the computer.

- Gantt Manpower Chart - The Gantt Chart graphically displays each activity in bar-chart form and the associated float. The cumulative manpower is displayed at the bottom of the sheet for leveling purposes.

- Project Schedule - The Project Schedule is the official issue of the optimized (leveled) schedule dates for each activity.

- Manpower Control System (MCS) - The MCS is a data-processed report that accumulates all manhour charges, remaining manhours, actual dates and projected dates. This document is the official drawing list, and the current status of each drawing/specification is maintained throughout the Project. Exception lists and summary reports are included.

- Design Engineering Progress Curve - The progress curve displays actual progress versus the planned curve.

Design Engineering Progress Graph - The progress (manpower) graph displays the actual manhour loading versus the planned manhour loading.

- Procurement Schedule - A list of all scheduled purchases to be made via requisitioning by the engineering departments. Also included are required vendor drawing and equipment/material delivery dates.

- Piping Status Report - An activity/isometric oriented, data-process generated report that indicates the status of each piping isometric during pipe installation. 
- Construction Curves \& Graphs - The progress curves display the scheduled and actual progress. The manpower charts display the scheduled and actual manpower loading by craft and work categories.

\section{A.3.3 COST REPORTING AND COST ENGINEERING}

The Cost Reporting and Cost Engineering services (Control Engineering) will provide an organized record of actual and forecasted Project costs by means of various integrated computerized systems.

The following items illustrate the principal aspects and documents of the Control System to be utilized for the Keystone Project.

- Home Office Report-Project Summary - Section of data processed Project Cost Report reflecting budget, to-date, estimate-to-complete and indicated final costs for home office payroll and out-of-pockets by main category.

- Expenditure Forecast (or Cash Flow) - Displays rate of expenditure of total project cost over the duration of the Project.

\section{A.3.4 ESTIMATING}

The Estimating Department is charged with the responsibility of providing complete estimating services in connection with Keystone Project execution operations. The department's principal function is that of taking an engineering concept and converting it into costs. The engineering concept may range from a few words to a highly developed design package; it is the Department's responsibility to ensure that the scope provides for the totality of the proposed Project features.

Once an estimate is made, it may become the budget for cost control of operations. In this regard, the department plays a continuing role in a Project by way of budget maintenance in the form of adjustments for approved change orders and revisions to reflect changes in method of execution. In addition the department is called on to prepare estimates comparing the cost 
of utilizing various methods, materials, or types of construction. Also, during the Project, the department may be called upon to re-estimate the Project or any part thereof on the basis of final design data.

Estimate Preparation

The data provided by the various departments is shown on the preceding flow chart. The information which arrives first is usually the equipment list and data sheets. Generally, this will form the major section in any given estimate. Various standard estimate detail sheets are used to record data on equipment and a typical sheet for pumps is appended. Like items of equipment are grouped together, their estimated costs totaled and brought forward to the equipment summary sheet. The total from this equipment summary is carried forward to the appropriate line on the overall estimate summary sheet.

Bulk materials such as piping, instruments, electrical, concrete, structural steel, etc. are entered and priced on standard estimating detail sheets. Again, the total by category for the various bulk materials are brought forward to the overall summary sheet. The foregoing categories, i.e., equipment and bulk materials, form what is called Direct costs and are totaled as such on the overall summary sheet.

The next category, Field Distributables or Field Indirect costs as they are sometimes known, are estimated by the Construction Department with the exception of payroll taxes, insurance, union benefits and sales tax, which are developed by the Estimating Department. A standard summary sheet and a typical detail sheet are included.

The next category of costs called Home office includes the costs of engineering, purchasing, project management and all of the services associated with a project that are performed. These costs are developed on detail sheets and summarized on a home office summary sheet and the total is brought forward to the estimate summary sheet. 
The three aforementioned groups of costs, i.e., direct costs, field distributables and home office, represent estimated "costs" to which are added contingencies, process fees, special allowances overheads and profit.

\section{A. 4 MANAGEMENT MASTER PLAN}

The detailed Management Master Plan for the Keystone Project will be developed during the first three months of a firm decision to proceed. The following is a preliminary outline of this Management Master $P l a n$, which is divided into five main steps:

1. Mobilize Project Task Force Management

2. Finalize Goals and Objectives for the Project

3. Review the Basic Data and Work Completed to Date

4. Develop Master Plan into Detailed Plans and Work Packages

5. Implement Master Plan - Engineering and Procurement

\section{Mobilize Project Task Force Management}

The EC will begin to assemble the management team within one week of notification. This will include the Project Manager and approximately half of the total managers on the Project Task Force. The remainder of the organization required will be in place within six to eight months. The Project Task Force Management (PTFM) under the direction of the Project Manager will plan, organize, direct and control the Project utilizing systems and procedures developed and agreed to.

\section{Finalize Goals and Objectives}

The Master Plan must take into consideration not only the Project Task Force Management goals but also the overall Keystone objectives. Once the PTFM is mobilized, a kick-off meeting will finalize the overall detailed goals and objectives for the total Project. 
3. Review Work to Date

After detailed goals and objectives have been finalized, it will be necessary to review the basic design data and work completed to date. The various managers, after reviewing the work to date, will establish the starting point for the Master Plan development. A final design basis will be established for each key project element 1 isted below:

Air separation and oxygen compression

Liquid oxygen storage

Coal receiving and storage

Coal preparation

Coal pressurization and feeding

Coal gasification and cyclones

Heat recovery and steam generation

Ash handling

Raw gas quench

Fines removal

Shift conversion

Sour water stripping and ammonia recovery

Liquid ammonia storage and transfer

Acid gas removal

$\mathrm{CO}_{2}$ recovery and storage

Liquid $\mathrm{CO}_{2}$ storage and transfer

Sulfur recovery

Sulfur storage and transfer

Methanol synthes is

Steam-methane reforming

Methanol distillation

Methanol storage and transfer

Water treatment (primary, BFW, CW)

Utilities

Waste water collection and treatment

Flare and thermal oxidizer 


\section{Develop Master Plan into Detailed Plans and Work Packages}

The managers on the Project Task Force Management (PTFM) Staff are responsible for the various individual work plans that will make up the Master Plan. One of the main functions of the PTFM at the beginning is the Master Plan development. Each of the managers reporting to the Project Manager will prepare the detailed step-by-step plan for the development of the areas within $h$ is responsibility. The following are some of the major areas that are addressed in the development of the management Master Plan.

- Engineering Management P Tan

- Site development

- Testing program to establish crushing strength, screenability and expected fines production

- $\quad$ Front-end engineer ing packages for process systems

- Plan for licensor selection, evaluation and completion of front-end package (s)

- Total Project utility balances in order to define utility systems

- Front-end packages for utility systems

- Front-end packages for the various support facilities

- Project general specifications

- Engineering requisitions for long delivery equipment items

- Material handling, stockpiling, and feed systems

- Plan for the various testing programs required for facilities

- Overall plot plan for the total facilities including access roads, railroads and drainage facilities

- Electrical distribution plan, interconnecting sewer and piping systems and any facilities required to interconnect the various units of the plant

- Define interface points and responsibilities for each of the task force units including all subcontracted process units 
- Material Management Plan

- Overall Project procurement plan

- Purchasing plan for blanket orders, bulk materials and long delivery equipment

- Overall project procurement procedures

- Individual plans and procedures for the overall project buying and expediting

- Inspection and traffic plans and procedures

- Subcontracting plan which will include uniform contract terms and conditions

- Material control coordination plan

- Controls Plan

- Overall Project control systems in the areas of cost, schedule, estimating, accounting and reporting

- Project accounting systems and procedures

- Monthly Project reports

- Project procedures manual

- Project management and control manual

- Overall Project cost control plan

- Establish systems and procedures for integrating overall Project costs with individual unit costs

- Overall Project plan and schedule

- Systems and procedures for each engineering contractor

- Estimating plan for the overall Project 
APPENDIX B

PR IME CONSTRUCT ION CONTRACTOR -- CONSTRUCTION ACTIVITIES PLAN

$4078 \mathrm{E}$

$B-1$ 


\section{APPENDIX B \\ PR IME CONSTRUCTION CONTRACTOR -- CONSTRUCTION ACTIVITIES PLAN}

This Appendix describes the construction activities to be performed by the prime construction contractor during construction of the Keystone Project.

\section{B.I OBJECT IVES AND FUNCTIONS}

The prime construction contractor will be responsible to meet the following objectives and perform the following functions:

Objectives

- Construct all facilities within the established time schedules.

- Integrate Project facilities to achieve startup and operation at required production rates.

Functions

- Establish procurement interface with the architect/engineer.

- Expedite procurement performance to meet demands of construction schedule.

- Coordinate and manage effective construction and field subcontract activities in accordance with Project schedules, procedures and budget.

- Monitor progress versus schedule and cost versus budget.

- Monitor proper sequence of plant commissioning .

- Coordinate plant startup programs to demonstrate the performance guarantees of the process technology. 
- Provide plant operating personnel training programs.

- Provide comprehensive reports to all members of the Keystone Project Team on the status of the Project.

\section{B.2 CONSTRUCTION ORGANIZATION}

The field construction organization will be structured according to the following basic functional areas:
- Engineering
- Control
- Supervision
- Materials
- Administration

The engineering function encompasses, but is not limited to, quality control, field survey layout, site liaison with design engineering, coordination to minimize design conflicts and interferences, drawing and specification interpretation, control of field changes, office engineering, and control of field construction material requirements. It is important to note that the responsibility for quality control is assigned to the field engineering staff in order to keep it separate from the supervision (production) function. This avoids any compromising of plan and specification requirements because of production priorities.

All field planning and cost control systems are combined in the control function. Because time and cost are directly related, they can be administrated effectively by a comprehensive management program. The site construction management uses the control program to monitor the progress of the Project and to anticipate final costs and completion dates.

The supervision on the construction site is in direct charge of the production resources. Aided by the other functional areas, they marshall all the materials, coordinate the equipment and supervise the manpower to construct a facility. Various specialists, such as piping coordinators, craft 
superintendents, and subcontract administrators, are employed in this function to support the area superintendents who have the responsibility for well defined areas, sections or processes.

The materials function includes the effective receiving, handling, storing, distribution, administration, and control of all construction materials, both temporary and permanent. The control of storage areas, warehouses and storerooms is an important responsibility of the materials control staff. Field expediting falls within this functional area.

The field administration function handles the necessary support services, such as field purchase orders, material and equipment requisitions, payrolls and data processing systems. The safety supervisor (staff support function) promotes and coordinates the company's comprehensive safety program.

\section{B. 3 POLICY ON DIRECT HIRE/SUBCONTRACT}

The majority of the general construction work will be performed on a direct hire basis, using the local unions as the source of supply for craftsmen. Specialty work, such as electrical, tankage, insulation and painting, is usually subcontracted. Subcontracting decisions will be greatly influenced by the availability of well-qualified local subcontractors, their special equipment, and the ir pool of experienced craftsmen.

If the decision is made to subcontract a specific portion of work the Construction Contractor in conjunction with the Architect/Engineer identifies and evaluates the qualifications of local subcontractors and national specialty subcontractors to prepare a bid list. The bid packages outlining the scope of work, conditions and terms are sent to those qualified bidders. The Construction contractor participates in the bid evaluation and subcontractor selection process.

As per the terms of the subcontractor's contract, $h$ is work is performed under the direction of the site construction management, within the planned schedule, and according to the plans and specifications. A field subcontract administrator monitors, evaluates and administers the performance of the subcontractor. 


\section{B. 4 PROCUREMENT CONTROL}

\section{Interface with Procurement}

In the early stages of the Project, the Construction Engineers work closely with the Procurement Department to assure that the movement of construction materials will be orderly, cost effective, and on schedule. Material handling analysis directives are issued to specify packaging and shipping methods. Delivery priorities and sequences are identified. Numbering and color coding are common practices. The delivery date for each article is set and becomes a part of a master delivery schedule system.

\section{Expediting}

As the Project proceeds, the flow of the materials is monitored and the vendor's ability to meet delivery dates checked. Expected performance is matched against the schedule. Good communication between the site forces and the Architect Engineer is essential and is aided by Status Reports. When the expected delivery of a unit does not agree with the Project schedule or requirements, action is taken to expedite its fabrication, assembly and/or delivery. While major critical items are expedited by teamwork efforts involving the Architect Engineer and the Construction Contractor, many situations are handled locally by the site's buyer or field expeditor.

Rece iving

The method of receiving and unloading construction materials will have been planned and specified earlier by the Construction Contractors material handling analys is directives, to save time and money in the field. The site construction forces utilize the proper equipment, such as forklifts, loading docks, ramps, and cranes, to unload materials. The best possible situation is the unloading of equipment, vessels, and other materials directly into their final location, thus avoiding multiple handling. Where this is not possible, the items are unloaded and placed in storage. 
All materials are counted, inspected and checked upon their arrival for compliance with the bills of material and purchase orders. Quality control inspections, in accordance with the approved checklist, assure compliance to plans and specifications. In the case of damages or shortages, appropriate reports are submitted to initiate corrective action.

The control of construction materials is maintained by the comprehensive material management system. This computerized system tracks the order and receipt of the material by purchase order and tracks the order, receipt, and issuance of materials by material classification. It includes receiving reports, inventory reports and status reports by purchase order and by material classification. The subsystems, in addition to the tracking, provide the data base and mechanism to track the flow of materials through final installation and completion. These systems generate reports to describe material status and monitor progress of the construction activities.

Warehousing

The materials delivered to the jobsite and not installed immediately must be properly stored. They must be protected from theft, pilferage and vandalism by well-planned security measures. If stored outside, the materials are protected from the weather and kept out of the dirt or mud by proper supports.

To accommodate the many articles that require inside storage, warehouses are used. If local conditions permit, existing structures can be used. Otherwise, it is necessary to erect site warehouse(s) which can later be used by the client for storage or shops. Speciality items such as instrumentation, electrical components and computers require climate controls. To meet these needs special, heated/cooled rooms are used.

Warehouses, tool rooms and storage areas are planned to make effective use of the available space. Pallet racks, special bins, hooks, and shelving fit into this planning. Areas of storage are subdivided and assigned code identifications. The material management system documents the storage location of each item by its location code. This facilitates orderly retrieval of all materials. 
Distribution

Because of planning, proper control, and properly run warehouses/storage areas, distribution of construction equipment and materials is accurate and efficient. Everything is ready and accounted for as it is needed. The material management system continues to track the flow of materials out of storage in order to account for its final disposition.

\section{B.5 LABOR RELATIONS}

Scope of Program

A craft labor survey will be conducted to determine the productivity and availability of labor in the specific locale. Information concerning labor productivity is obtained from local unions, surveys, contractor job histories, and concurrent area projects. Other factors such as job size, type of construction, and duration must be added to the equation. This information is essential in estimating total project cost and as a guide in measuring actual productivity.

Labor availability is obtained in much the same manner. Local chambers of commerce, newspapers, and real estate boards all contribute to the total picture. Availability is plotted against manpower requirements to determine when shortages may occur by craft and skill.

A pre-job labor conference is held with all necessary local and national union officials, together with the contractor's Project Manager, Labor Relations Manager, and Site Construction Manager in attendance, prior to field mobilization. A review is made of the scope of work and manpower requirements. The review includes all major equipment to be installed and the work is assigned by agreement, thereby minimizing jurisdictional disputes during construction. 
The contractor will be capable of employing craftsmen under the terms of National Labor Agreements between the Company and various Building Trades Unions affiliated with the AFL-CIO. In addition, the contractor must have negotiated, throughout the country, project agreements which supersede the local and national agreement.

\section{B.6 SAFETY}

\section{Scope of Program}

There is a positive correlation between a well managed job and a safe job. A job that is below cost and ahead of schedule is a job with low frequency and severity rates for lost time accidents. Because of the size of the Project and the number of people involved in the construction phase, it is essential that a uniform set of safety standards be established at the beginning of the project.

The standards will be administered uniformly throughout the life of the Project. Contractors will be working in close proximity to each other and, in many cases, labor will be shifting from one contractor to another as work progresses, so it would be self-defeating to have each contractor living by a different set of safety requirements.

The procedure below will be followed to assure the establishment of such a uniform safety program:

- The contractor will assign an experienced, highly qualified Safety Supervisor to administer the site safety program. He will be fully supported by management and will be assisted by a staff of safety inspectors, the number of which will be based on the demands of the project. 
- Prior to the start of field construction, a detailed Project Safety Manual will be developed (if one is not already implemented by the General Contractor) by the Safety Supervisor assigned to the project, the Construction Project Manager, Manager of Safety and the Keystone Project Safety Review Board. This document will be the bas is for the safety program for the contractor and all its subcontractors for the duration of the project.

- Included in this Project Safety Manual will be an outline of the first-aid program and fire prevention program. A fully equipped first aid facility with an ambulance will be required at the start of the project.

- The project safety requirements will be a part of each Invitation to Bid and subcontract. The subcontractor's past accident experience will be strongly considered prior to award of the subcontract. A pre-award safety meeting will be held with each subcontractor prior to the subcontractor's mobilization. Each will be required to have as a minimum the following safety program.

- The Field Safety Supervisor will participate in the pre-job labor conference and will reaffirm to the Building Trades the contractor's effort to prevent accidents on the construction site.

- Each subcontractor's safety representative will meet with the general contractor's Field Safety Supervisor at a week ly site safety meeting to review safety related problems and make recommendations to management in areas which require improvements.

- Safety inspections of the subcontractor's operations will be conducted on a daily basis and the subcontractor will be advised in writing of any deviations from the project safety program.

- The Field Safety Supervisor will have continual contact with each individual subcontractor in order to coordinate their work in a safe manner. 
- Construction Managers are evaluated yearly, and the ir salary increases, at least partially, are based on their safety results. The safety statistics are monitored closely so that the contractor is constantiy aware of the status of each project compared to the other projects and the company goals.

As the Project proceeds, the safety program and project safety manual will be continually revised and updated to reflect changes in the contractor's/ subcontractor's operations, and state and local government operations.

\section{B.7 FIELD PLANN ING AND SCHEDUL ING}

Field planning provides management a tool for attaining effective schedule control. The Field Planner(s) accomplishes this by providing management with information and interpretation of the status of the CPM Schedule (Time Grid) based upon actual and anticipated field progress. He also analyzes and interprets the effects of any deviation from the established CPM Schedule.

The Field Planner(s) accumulates all information necessary for short-interval scheduling with in the parameters of the CPM Schedule. He continuously reviews the status of required engineering information (drawings, specifications, etc.) and procurement delivery information (equipment and bulks) issued through the Architect Engineers' home office. Using this information, he develops a two-week plan indicating planned construction activities with the required manpower and construction equipment to accomplish these tasks. He then reviews the planned activities, manpower and equipment usage with each individual superintendent and incorporates the revisions and comments into the plan. A schedule review meeting is then held with the construction staff to present and discuss the two-week plan. This allows any conflicts or problem areas to be defined and dealt with prior to issuance of the final two-week plan.

The Field Planner also monitors and compares actual versus planned progress and updates the CPM Schedule and other schedule related documents (i.e., fragments of individual subcontractors or critical areas). He maintains a 
close liaison with the Construction Project Manager in dealing with schedule related matters. He works closely with the Field Cost Engineer insuring proper data input into the Construction Status Reports (CSR).

\section{B.8 FIELD COST ENGINEERING}

Field Cost Engineering provides management a tool for attaining effective cost control. The Field Cost Engineer(s) accomplishes this using trend analysis and total job forecasting. All cost related information is channeled through the Field Cost Engineer(s).

The Field Cost Engineer(s) keeps the Construction Project Manager continually advised as to the cost status of the Project. He prepares, on a monthly basis, a forecast of all direct material field accounts, a cash expenditure forecast of all field related costs, and a summary of all subcontract extra work orders with an estimated labor and material amount.

The Field Cost Engineer(s) prepares quantity takeoffs and maintains records of actual quantities installed. These are used to prepare and issue unit cost reports biweekly. These Unit cost Reports are the basis for trend analysis and subsequent cost forecasting.

The Field Cost Engineer(s) works closely with the Field Planner in the verification and posting of all field requisitions (including subcontracts), extra work orders, assuring proper coding of the daily craft time sheets, and the input of all necessary data onto the field labor summary for the Construction Status Report (CSR).

\section{B.9 SITE SUPPORT}

\section{Temporary Facilities}

The pre-mobilization site survey will be undertaken with the cooperation and assistance of Keystone Associates. The purpose of the survey will be to obtain information that will have a direct or indirect effect on the estimating, planning, and control of a contract. 
The survey will answer questions relating to site conditions such as interferences, plant traffic patterns, access, storage areas, parking areas, availability of utilities, potential locations of construction facilities and ongoing work in the area. Fire, hospital, ana first-aid facilities, the owners' organization and requirements pertaining to permits, inspections, security, safety, work rules, tie-in work, contracts/subcontract, local or governmental restrictions, soil conditions, drainage, weather, communications, labor availability, and other pertinent information items will be identified.

In order to avoid "happenstance" or "evolutionary" development of site utilization, Construction Engineers will plan, develop and produce detailed drawings for the purchase and installation of all the required facilities. These drawings will cover, but not be limited to, such items as fencing, gates, offices, parking, utility stations, warehouses, laydown areas, valve yards, fuel storage, tool rooms, medical center, shops, and craft changehouses. Effective site utilization will be based on the areas available, requirements, and flow patterns, adroitly assembled by experienced professionals.

\section{Support Services}

A major function in the general day-to-day operations of any business is the task of promoting efficiency. The coordination of the use, maintenance, and security of all construction temporary support facilities is such a task.

Actual day-to-day functions will entail such activities as: the installation, care and maintenance of roadways, parking areas, utilities, communications, laydown and storage areas, drainage systems, and security devices (fencing, lighting, etc.); the security of the entire site, control of the flow of people and materials, trash clean-up and disposal; and the coordination and monitoring of the use of these facilities to insure maximum utilization and effectiveness.

4078E 


\section{B. 10 CONSTRUCTION ENG INEER ING}

Constructability

The Prime Construction contractor provides a strong construction-oriented message throughout the total Project development, realizing that exceptional front-end planning will cause positive final results. This objective will be implemented by the Construction Engineering staff. The Documentation and Service Flow Chart for construction engineering presents this idea.

During the course of the actual design of all the facilities, permanent and temporary, the construction Engineers will be actively involved in seeing that constructability is engineered into the designs with special efforts to maximize shop assembly and modular designs.

In addition, before any contract/subcontract is awarded, the contractor's Construction Engineers will furnish input based on the review of documents, past experience, vendor pre-selection meetings, and actual site conditions. Before bidding, each bidder will receive copies of explicit instructions relating to Construction's requirements, which will avoid any later misunderstandings.

Shop Fabrication and Field Follow-through

An integral part of management planning will be the sequencing of design, fabrication and deliveries to satisfy construction needs. The construction engineers will play a major role in the establishment and follow-through of this effort. Regular meetings with the Architect Engineer will help emphasize construction requirements. The turnkey contractor's interdepartmental cooperation will spearhead the success of these efforts. The contractor's Construction Engineers will supply construction information to the Project buyers via a formal material handling directive form. These directives will be supplied for each requisition or purchase order. Instruction will be given as to required delivery dates, special sequencing, transportation modes, special packaging, special shop assembly notations, lifting devices, tagging, and other considerations.

$4078 E$ 
In order to effectively and efficiently handle the volume of materials and equipment coming to the Project, simple yet effective coding and tagging will be used. This will expedite receiving so that lengthy and often hard to distinguish tag numbers will not be initially relied upon. These visual codings will greatly simplify retrieval from storage yards and aid erection.

Subassemblies and Modularization

The contractor's Construction Engineers will, in conjunction with the Architect Engineer, conduct in-depth studies to define and detail maximum pre-assembly and shop fabrication possible and to insure that ease of erection is optimized.

To accommodate large pre-assemblies, modules, heavy or large vessels and equipment, the contractor will make detailed plans for each lift, listing all necessary equipment, temporary foundations or supports, specifications of the item being lifted, schedule, and effect on surrounding work areas. Schedules will be coordinated to insure that the idle time for expensive construction equipment is minimized. The major equipment heavy lift chart presents the methodology of managing major lifts.

\section{Productivity Improvement}

Recognizing the significant encompassing benefits of increased construction productivity, the contractor will develop a productivity improvement program which is administered and directed from the field. The program will work in concert with other programs of construction engineering, material handling, quality control, safety, and labor relations to effectively reduce final in-place erection costs. Some of the methods utilized in the program are:

- Formal indoctrination of union supervisory personnel.

- Management training through supervisory workshops.

- Worker participation on jobsite productivity committees.

- Work method studies.

- Recognition and awards. 
Through these activities and others, such as delay surveys and craftsmen questionnaires, the contractor can maintain an insight into the Project that is not available through conventional-type reporting, and identify and eliminate productivity restraints and employee demotivators before they can negatively affect the Project.

\section{B.11 FIELD QUALITY CONTROL}

Scope of Program

Utilization of a meaningful quality control program is initiated under approved construction management standards in which parameters are established for minimum requirements, checklists are provided and various forms made available. Primary and secondary field assignments are made for every item governing the checklist, carried out and documented by individuals of assorted speciality classifications, some of whom are trained and certified by the American Welding Society (AWS).

The checklist covers areas such as site preparation and grading, roads and paved areas, fencing, storm drainage and sanitary sewers, piping and plumbing, underground electrical, piling, concrete, grout, structural steel, miscellaneous steel, buildings/architectural, hangers and supports, equipment, vessels, tanks, ducts, storage and maintenance, electrical, welding, protective coatings, thermal protection and testing.

Documentation verifies that construction was performed in accordance to the plans, specifications, codes and regulations. To ensure that the quality control program is rigidly enforced, periodic audits are performed and documented. These audits serve not only as a check for compliance of the system but set forth a basis for an annual productivity award. This award recognizes excellence in achieving a high level of quality control performance while promoting overall awareness of quality control requirements. 
Objectives

The importance of the implementation of an accurate and expeditious quality control program is to promote and assure construction of safe and reliable plant facilities. Past experience has only enforced our dedication to ensure quality without undue imposition on the continuity of work.

The contractor's interest in assuring quality will be stressed throughout $h$ is organization and will be an integral segment of the total construction effort. 
APPENDIX C

DETAILED ASSUMPTIONS UNDERLYING THE BASE CASE FINANCIAL PROJECTIONS

$4078 E$

$C-1$ 


\section{APPENDIX C}

DETAILED ASSUMPTIONS UNDERLYING THE BASE CASE FINANCIAL PROJECTIONS

(ALL COSTS EXPRESSED IN JANUARY 1982 DOLLARS)

\section{Plant Capital Costs ( $\$$ millions)}

\begin{tabular}{|c|c|c|c|c|c|}
\hline Year & Land & $\begin{array}{c}\text { Site } \\
\text { Improvements }\end{array}$ & Buildings & $\begin{array}{l}\text { Engineering \& } \\
\text { Other Capital* }\end{array}$ & Tota 1 \\
\hline $\begin{array}{l}1983 \\
1984 \\
1985 \\
1986 \\
1987\end{array}$ & 2.2 & $\begin{array}{l}2.4 \\
5.7 \\
5.7 \\
2.4\end{array}$ & $\begin{array}{l}12.1 \\
22.1\end{array}$ & $\begin{array}{r}8.2 \\
97.2 \\
105.4 \\
150.1 \\
133.3\end{array}$ & $\begin{array}{r}8.2 \\
102.3 \\
123.2 \\
177.9 \\
135.7\end{array}$ \\
\hline TOTAL & $\overline{2.2}$ & 16.2 & $\overline{34.2}$ & 494.7 & 547.3 \\
\hline
\end{tabular}

* Includes builders all-risk insurance costs.

Pre-Production Expenses ( $\$$ thous ands)

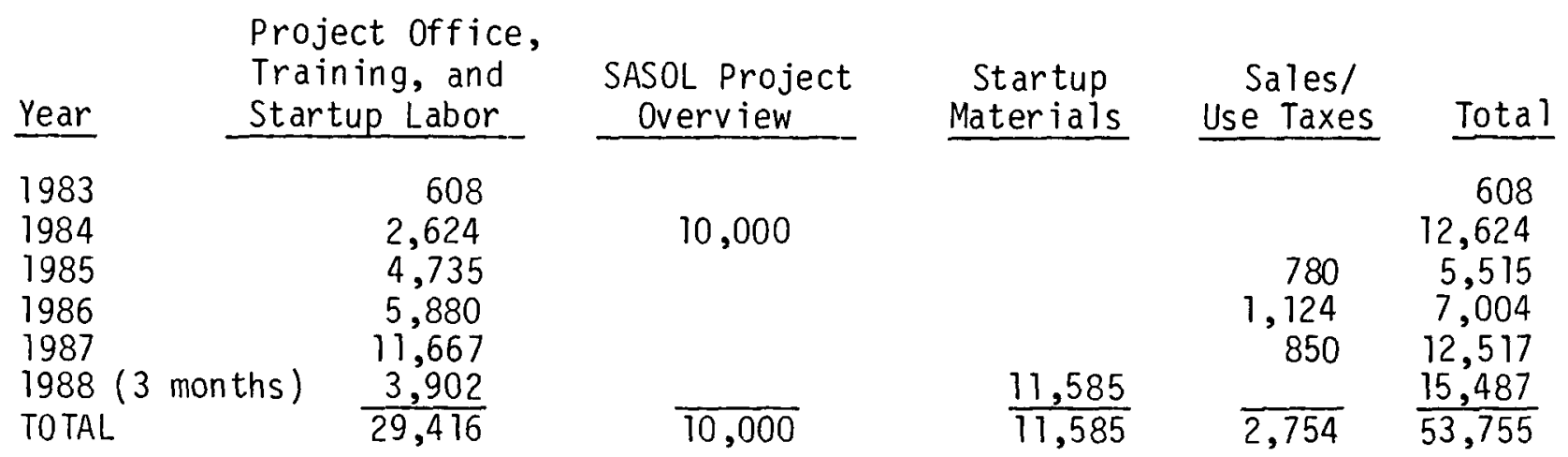

Work ing Capital

Inventories

- coal

- catalysts and chemicals, water, diesel fuel

oil, operating and maintenance supplies

- methanol

one month

14 days

7 days

Accounts Receivable

one month of sales 
Plant Performance

Average capacity factor: 1988 ( 9 months) $58 \%$

$1989 \quad 79 \%$

$1990 \quad 81 \%$

subsequent years $\quad 82 \%$

Thermal efficiency

$56 \%$

Revenues

Methanol production at $100 \%$ capacity 204 million gallons/year

Methanol price

support price through 1997, then Pace price

By-Products

Sulfur

Carbon dioxide

Ammonia
Annual Sales a 100\% Capacity

29,200 tons/yr 305,140 tons/yr 2,555 tons/yr
Sales Price per Ton

$\$ 150$

30

200

Annual Operating Expense

Annual coal consumption at $100 \%$ capacity

853,000 tons

Delivered coal costs with higher heating value of 12,300 Btu/lb

$\$ 27$ per ton

Costs

Personnel:

Classification

Senior management

Other managerial and supervisory

Engineer and professional

Technicians and draftsmen

Crafts

Operators

Clerical

Laborers

Total

Benefits At $40 \%$

Total Annual Personnel cost
Aver age

Annual Pay

$\$ 51,430$

31,000

35,000

22,000

24,000

22,000

17,000

15,000
Total Annual
Cost

$\$ 360,000$

$1,271,000$

$1,995,000$

$1,540,000$

$1,152,000$

$3,740,000$

357,000

150,000

$\frac{10}{424}$

$4,226,000$

$\$ 14,791,000$

$4078 \mathrm{E}$ 


\section{Electricity:}

KW

Cost per KW

Cost per KWH
54,720

$\$ 6.574 /$ month

$34.77 \mathrm{mills}$

Natural gas:

Usage at $100 \%$ capacity

Cost for first $8 \mathrm{million} \mathrm{scf} / \mathrm{mon}$ th

53.46 million scf/month

Cost over $8 \mathrm{million} \mathrm{scf} / \mathrm{month}$

$\$ 5.0286$

4.7590

(Note: The capital costs include $\$ 2.1$ million for a gas pipeline; gas bills for the first six years are reduced in equal installiments for $120 \%$ of this cost.)

Annual operating supplies:

Operating labor costs ( $\$ 6.4$ million) $\times 30 \%$

Annual maintenance supplies:

Plant capital costs excluding 1 and $\times 1.24 \%$

Catalysts and chemicals at $100 \%$ capacity: $\$ 3,921,000$ per year

Water:

Annual usage at 100\% capacity

Cost per thous and gallons

1,205 million gallons

\$0.125

Insurance:

$0.6 \%$ of inventories and $\mathrm{pl}$ ant capital costs excluding 1 and

Real Estate Taxes:

65 mills applied to $30 \%$ of $\$ 32$ million in qualifying costs

(Note: The $\$ 4.8$ million provided by the Department of Energy for the feasibility study is assumed to be repaid, together with interest accrued at $5 \%$ annually, in 1988.)

$4078 \mathrm{E}$ 


\begin{tabular}{lcc} 
& \multicolumn{2}{c}{ Annual Rate } \\
& $1982-1990$ & $1990-2010$ \\
\cline { 2 - 3 } General inflation & $7.0 \%$ & $6.0 \%$ \\
By-product revenue & $7.0 \%$ & $6.0 \%$ \\
Capital costs & $9.0 \%$ & $7.0 \%$ \\
Coal costs & $9.0 \%$ & $7.5 \%$ \\
Electricity & $8.0 \%$ & $6.5 \%$ \\
Project personnel & $7.0 \%$ & $8.0 \%$ \\
Natural gas & $14.0 \%$ & \\
Operating and maintenance supplies, & & $6.0 \%$ \\
catalysts and chemicals, water, & & \\
insurance, and real estate taxes & $7.0 \%$ & $6.0 \%$ \\
Methanol (from projected Pace price & & \\
in year 2000) & &
\end{tabular}

Tax Treatment

Tax depreciation

Interest during construction

Pre-production project office training and startup costs, SASOL Project overview and sales/use taxes

Income tax rate

Investment tax credit

Energy tax credit
Buildings and site improvements-- 15 yr ACRS Engineering and other capital---- 5 yr ACRS Basis reduced by half of the tax credit

All capitalized with deductions taken at the same rate as depreciable costs. Basis is reduced by half the tax credit.

Expensed as incurred

$51.67 \%$ to incorporate the combined effect of federal and state rates

Applied to two-thirds of site improvement costs, all "engineering and other capital" costs and interest during construction, under a section 266 election, in proportion to which the previously-incurred capital costs were assumed to be eligible for the credit. Taken on a project expenditure basis except for 1983 which is recognized when the plant is ready for use (1988).

None 
Tax credit

Depreciation

Interest During Construction

Pre-production Project Office,

Training and Startup Costs,

SASOL Project Overview and

Sales/Use Taxes

Venturers' Investment Income

Balance Sheet

Current Assets

Net Worth

Financing Assumptions

Debt (all non-recourse)

Annual Interest Rate

Refinancing Charge \& Expenses
Flowed through to equity sponsors in year operations commence (1988)

Life based upon project operating period (22.5 years); full cost bas is used with 1988 adjustment to recognize reduced tax basis.

Capitalized and subsequently amortized at the same rate as depreciable costs.

Expensed as incurred

Equal to venture income before tax. (No income tax is paid by the venture.)

The sum of inventories and accounts rece ivable

Annual variation equal to the change in financial statement IAT minus the change in net cash flow

$75 \%$ of pre-production costs in short-term obligations with refinancing to long-term instruments in the first full year of operations (July, 1989). Principal payments are made in semiannual installments over twenty years without a grace period. Accrued interest is due at the time of each payment of principal

$12 \%$ (includes $0.5 \%$ SFC loan guarantee fee and $0.75 \%$ risk premium)

$1.5 \%$ of long term debt 